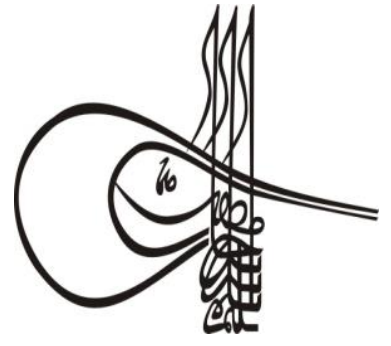

Received/Geliş: 31.08 .2019
Turkigh Studies

\section{Language and Literature}

Volume 14 Issue 3, 2019, p. 1625-1668

DOI: 10.29228/TurkishStudies.36827

ISSN: 2667-5641

Skopje/MACEDONIA-Ankara/TURKEY

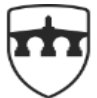

INTERNATIONAL BALKAN UNIVERSITY

EXCELLENCE FOR THE FUTUR IBU.EDU.MK

Research Article / Araştırma Makalesi

Article Info/Makale Bilgisi

Gor Report Dates/Rapor Tarihleri: Referee 1 (05.09.2019)-Referee 2 (23.09.2019)- Referee 3 (16.09.2019)

This article was checked by iThenticate.

\title{
ÜSTKURGUSAL DÜZLEMDE ANLATILAR SERİİ: ÜÇ ANLATI
}

\author{
Maksut YİĞİBAŞ*
}

\begin{abstract}
öz
Bu çalışmada Hilmi Yavuz'un Üç Anlatı adlı eseri, postmodern bir anlatım aracı olan üstkurmaca tekniği bağlamında incelenmiş ve bu tekniğinin eserde nasıl uygulandığ izah edilmeye çalışılmıştır. İlk basımı 1995 yıllında yapılan Üc Anlati; Taormina (1990, s. 5-79), Fehmi K.'nın Acayip Serüvenleri (1991, s. 81-158) ve Kuyu (1994, s. 159-214) olmak üzere üç farklı anlatı bölümünden oluşur. Edebiyatın pek çok alanında nitelikli eserler ortaya koyan, tarihî mirastan ve gelenekten yararlanan Hilmi Yavuz, Üç Anlatı'da yazar, anlatıcı, eleștirmen ve okuyucu olmak üzere çeşitli şekillerde okuyucunun karşısına çıkar. Üç Anlatı farklı üstkurgusal düzlemlerin birbiri içine geçtiği, uzamlar arasında gelgitlerin yaşandığı, dil oyunlarının sıkça yapılarak anlatıcı karmaşasının yaşandığı ve okuyucunun, zihninde cevapsız pek çok soruyla bırakıldığı postmodern tarzda yazılmış gerçek bir üstkurmaca eserdir. Üç Anlatı aslında Hilmi Yavuz'un çocukluğuna ve bilinçdışına yapılan istem dışı bir yolculuğun akışıdır; bu nedenle eser, felsefî ve psikolojik veriler ışığında ilerleyen üstkurmaca teknikleriyle çözümlenmeye imkân tanır. Postmodern bir tarzda yazılan Üç Anlatı'nın en önemli özelliği olay örgüsü ve anlatıcı düzleminde kendini gösterir. Klasik ve modern anlatılarda güçlü olay örgüsü, belirli bir anlatıcının yerini postmodern eserlerde belirli olay örgüsünün ve anlatıcının olmadığı anlatılar alır. Böylece anlatı pek çok açıdan muğlak, okuyucunun anlaması için çözümlemesi gereken bir yazın dünyası hâline gelir.
\end{abstract}

Anahtar Kelimeler: Hilmi Yavuz, Üç Anlat1, Üstkurmaca. 


\title{
SERIES OF NARRATIVES IN METAFICTIONAL PLANE: THREE
} NARRATIVES

\begin{abstract}
In this study, Hilmi Yavuz's work Three Narratives was analyzed with metafiction technique, which is a postmodern expression tool and it was tried to explain how the metafiction technique was applied in the work. Three Narratives are published for the first time in 1995, consists of three different narrative sections as; Taormina (1990, pp. 5-79), Fehmi K.'s Curious Adventures (1991, pp. 81-158) and The Well (1994, pp. 159214). Producing quality works in many areas of literature and using the historical heritage and tradition; Hilmi Yavuz meets with readers in many ways, such as a writer, narrator, critic and a reader in Three Narratives. The Three Narratives are a work where different metaphorical planes are intertwined, there are tides between spaces, and narrative complexity is experienced by performing language games frequently. It is also a true metafiction written in a postmodern style in which the reader is left with many unanswered questions in his mind. Three Narratives is actually an involuntary journey of the writer to his childhood and his unconscious; thus, the work facilitates an analysis with metafiction techniques proceeding in the light of philosophical and psychological data. The most important feature of Three Narratives which was written in a postmodern style is its plot and narrator. In classical and modern narratives, the narratives containing a strong plot and a certain narrator are replaced by narratives with no certain plot and narrator in postmodern works. Thus, the narrative becomes a literature world where many things remain ambiguous and which needs to be analyzed and comprehended by the reader.
\end{abstract}

\section{STRUCTURED ABSTRACT}

In this study, Hilmi Yavuz's work Three Narratives was analyzed with metafiction technique, which is a postmodern expression tool and it was tried to explain how the metafiction technique was applied in the work. Three Narratives are published for the first time in 1995, consists of three different narrative sections as; Taormina (1990, pp. 5-79), Fehmi K.'s Curious Adventures (1991, pp. 81-158) and The Well (1994, pp. 159214).

The most important feature of Three Narratives which was written in a postmodern style is its plot and narrator. In classical and modern narratives, the narratives containing a strong plot and a certain narrator are replaced by narratives with no certain plot and narrator in postmodern works. Thus, the narrative becomes a literature world where many things remain ambiguous and which needs to be analyzed and comprehended by the reader.

Producing quality works in many areas of literature and using the historical heritage and tradition; Hilmi Yavuz meets with readers in many ways, such as a writer, narrator, critic and a reader in Three Narratives. Three Narratives is actually an involuntary journey of the writer to his childhood and his unconscious; thus, the work facilitates an analysis 
with metafiction techniques proceeding in the light of philosophical and psychological data.

In Three Narratives, the writer creates a new fiction structure which is not so familiar to the reader by the process in which it is written and where philosophy is included in literature, using an unusual expression technique. Including the reader in the text; he tries to show the reader how the text was written and thus to feature the writing process of the text. In the narratives, the writer presents people and life experiences from different times and spaces in an integrity within the same space frame without posing any time obstacles between them in a carnivalesque way.

While revealing the writing process in his aforementioned work; Hilmi Yavuz actually experiences a purification (catharsis) expressed by Aristo and also the desire of realizing himself by comprehending his existence. In addition, Three Narratives is evaluated as an autobiographic work as it bears the traces of the writer's childhood, youth and old age. Designing a philosophical fiction novel; the writer primarily aims to create a new space design in his mind. He expresses that as follows; "I have found the word. Now I should look for its image!" (p. 9). The space which is called "Taormina" is an imaginary space created with discourse language and the writer's power of creating an image. It is seen that the word Taormina denotes a space of shelter and salvation where the writer has found his own existence.

The reality-fiction paradox which is an important characteristic of metafiction narrative is encountered throughout Three Narratives. It is encountered as space in Taormina; narrator and fiction in Fehmi K.'s Curious Adventures; fiction, narrator and time in The Well. The principal fiction of Fehmi K.'s Curious Adventures comprises of narrative problem, which is embraced as an irony and the narrative itself, which is transformed into fiction. Based on writing a narrative parody; Fehmi K.'s Curious Adventures focuses on how a narrative is fictionalized.

Published by Hilmi Yavuz in 1990; The Well contains the intricacy of Taormina and Fehmi K.'s Curious Adventures within the context of content and especially narrator. It portrays a journey to the subconscious. "Our life is a poem!", a quote repeated by Izzeddin Sadan who is one of the narrative heroes expresses the complexity very well. The statement contains a social dimension as well.

The Well includes some strange and unusual individuals, events and rumors even though it does not bear these characteristics directly. Majority of them take place and are heard in Siirt, a southeastern city during Hilmi Yavuz's childhood in relation with the well. Hard and freshwater wells in his grandfather's mansion, the stories told by his friend Muhammed Emin and their visit to Ibn Mukanna's house together comprise the fantastic dimension of his narrative.

In his narratives, Hilmi Yavuz mocks the reflective/traditional and modern understandings of novel with an irony in line with the postmodern approach. In Taormina, irony is aimed at the understanding of intertextual relation of postmodernism. Thus, in the narrative, he finds provisions symmetrical with those received with the intertextual relation. On the other hand, in Fehmi K.'s Curious Adventures which is a parody 
example written on the basis of narratives and novels, he mocks the concept of quality reader that is a preference of modern literature and criticizes the elitism of modernism.

Together with the change of the reality perception in social, cultural and scientific areas, the literature changes its viewpoint of subject and object as well and what now matters is to express the literature and the act of writing rather than the subject. In this context, the metafiction techniques used in Three Narratives are as follows: 1. Nesting of Reality and Fiction, 2. Defamiliarizing of the Reader to the Text, 3. Being a Fiction in Which the Writer/Narrator Addresses to the Reader, 4. Being a Fiction about a Person Who Reads/Writes a Novel, 5. Telling a Fiction within a Fiction, 6. Making the Writing Process of the Text the Subject of the Text, 7. Being a Fiction in Which the Hero Addresses to the Narrator / in Which the Writer and the Hero Interact, 8. Collage/Montage, 9. The Writer's Being a Character in the Narrative, 10. The Narrator's Informing the Reader between the Lines, 11. Identification, 12. The Writer's and Narrator's Involvement in the Text, 13. Attracting the Reader's Attention to Fictional Elements, 14. The Hero's Awareness of His Fictional Character, 15. Measuring the Reader's Attention, 16. The Reader's Speaking in the Text and Involvement in the Text.

Keywords: Hilmi Yavuz, Three Narratives, Metafiction.

\section{Giriş}

Hilmi Yavuz, $\ddot{U} C ̧$ Anlatı'da sıra dışı bir anlatım tekniği kullanarak yazıldığı dönem dikkate alındığında okuyucunun alışık olmadığı, felsefenin edebiyata dâhil edildiği, yeni bir kurgu yapısı oluşturur. Okuyucuyu metne dâhil ederek metnin nasıl yazıldığını okuyucuya göstermeyi ve metnin oluşum sürecini ön plana çıkarmayı amaçlar. Öte yandan anlatıda, mekânın sınırlarının somut bir şekilde çizilmediği ve belirli bir çerçeve içinde sunulmadığ 1 görülür. Postmodern anlatılarda yaygın olarak görülen bu mekânsal boşlukları okuyucu kendi algısı ve becerisine göre doldurur, süsler ve canlandırır. Yazar eş düzlemde farklı nesnelerin, eylemlerin ve tanımların inşasını kendine özgü üslubuyla kurma yoluna girer. Yeni mekân ve nesne tanımlamaları; olanaklı ile olanaksızlığı, gerçek ve kurmaca dünyaları girift bir biçimde inşa eder. Böylece çoğulcu karmaşa/ "kavram kargaşası" (s. 20) gibi pek çok alternatif yaşam düzlemini iç içe sunularak okuyucuların üstkurgusal bir okuma yapmalarına olanak sağlar. "Taormina! Benim biricik büyülü-söz'üm: Taormina!... Sözcü̈̆̈̈ buldum, şimdi onun imgesini aramallyım!" (s. 9) ifadeleri bu yeni yapılanmanın en önemli göstergeleri olarak karşımıza çıkar.

$\ddot{U} c ̧$ Anlatı' da yazar, farklı tarih ve mekânlarda yaşamış insanları ve yaşanmışlıkları, aralarında zaman engeli taşımadan aynı mekân karesinde, bütünlük içerisinde karnavallaştırarak sunar. Kısacası yazar, postmodern anlatıların mekân anlayışının sunduğu rahatlı̆̆ı ve imkânı özgürce kullanma becerisine sahip olur. Postmodern anlatılarda mekân işlevsel bir özellik taşımaz, bu nedenle yüzeysel işlenir. Postmodern olay örgüsünde, gerçek ve kurmacanın bir aradadır ve çoğu zaman sarmal biçimde okuyucuya sunulur. Şahıs kadrosu olay örgüsünün figürleri olmasının yanında metnin oluşumuna katkı sağlayan, metni yönlendiren unsurlardandır. Anlatı kişileriyle birlikte zaman ve mekânın hem soyut hem de somut biçimde bir arada olabilirliği anlatı yazarının ve okuyucusunun fonksiyonlarını zenginleştirir. Özetle çağın getirdiği değişim ve imkândan edebiyat kendine fazlasıyla pay çıkartır.

Hilmi Yavuz, $\ddot{U} c ̧$ Anlatı'da yazma sürecini ortaya koyarken hem Aristoteles'in ifade ettiği arınmayı (katharsis) hem de varlığının bilincine vararak kendini gerçekleştirme arzusunu beraber yaşar. Nitekim Киуи adlı anlatısında "gökyüzünün lekesiz, saf ve temiz bir mavilik olarak görünüyor olması" (s. 168) ile kendi özgün yazarlı̆̆ının bilincinde olduğunu ve yazarlık kimliğini bulduğunu ifade eder. 
“...indiği her kuyuda yüzünü ylkama(sı)” (s. 168) ile de yazmış olduğu her eserden sonra "kendini gerçekleştirmesini/bulmasını ve kendi olmasını" dile getirir. Ayrıca her kuyuda yüzünü yıkama söylemi ile yazarın her anlatı sonrasında duyduğu rahatlama ve arınma kastedilir. Üç Anlatı yazarın çocukluk, gençlik ve yaşlılık dönemlerinden izler taşıması itibariyle otobiyografik bir eser olarak da değerlendirilebilir.

Felsefî bir kurgu romanı kaleme almayı tasarlayan yazar, öncelikle zihninde yeni bir mekân tasarımı oluşturmayı amaçlar. Bunu "Sözcü̈̆̈̈ buldum, şimdi onun imgesini aramalıyım!” (s. 9) şeklinde ifade eder. "Taormina" olarak adlandırılan bu mekân, söylem diliyle ve yazarın imge yaratım gücüyle oluşturulan düşsel bir mekândır. Taormina şüphesiz yazarın özgürce hareket ettiği bir "ben ülkesi”dir. $\mathrm{Bu}$ ben ülkesi yazarın kaçış yaptığı bir diyardır. "Ve ne zaman kendi kendime 'Taormina!' desem, aydınlı̆̆a boğuluyorum: uzak, güneşli bir deniz ve beyazllk. Bir yelkenli, belki. 'Taormina!' bu sözcük beni dinlendiriyor. Bu sözcük benim hem yaz'ım hem yazlı̆̆ım onun penceresinden şunlart seyrediyorum..." (s. 9) ifadesiyle yazar, okuyucuya kurmaca bir dünyanın kapılarını araladığını haber verir ve okuyucuyu bu kurgunun içine davet eder. Yazarın, bu sözcük benim yaz'ım derken "-1m” ekini kesme işareti ile ayırması, sözcüğün mevsim anlamının yanı sıra yazı yazma eylemini ve kurmaca anlamı içerdiğini vurgular.

Çocukluğu Taormina'da geçtiği için kendini bahtiyar sayan yazar, gerçek dünyanın sıkıntı ve sıradanlığından ancak büyülü bir mekân olarak tanımladığı Taormina'ya sığınarak kurtulduğunu ifade eder: 'Benim yine 'Taormina'ya, o büyülü söz'e, o imgeye dönmem gerekiyor. Çünkü ancak orada yazdlklarım ve düşündüklerimle, var oluşum bir anlam kazanıyor. 'Taormina' dışında yazdıklarımın tam bir bayağılık ve sıradanlık taşıdığını biliyorum artık. Bu yalıtkanlıktan kurtulmak için 'Taormina'ya siğınıyorum yine." (s. 52-53). Taormina, yazarın kendi var oluşunu bulduğu bir sığınma ve kurtuluş mekânı olarak anlatıda yer alır.

Üstkurmaca anlatının önemli bir özelliği olan gerçek-kurgu çelişkisi üç anlatının hepsinde kendini gösterir. Bu, Taormina'da yaşanılan mekân; Fehmi K.'nın Acayip Serüvenleri'nde anlatıcı ve kurgu; Kuyu'da kurgu, anlatıcı ve zaman bakımlarından ortaya çıkar. Nietzsche'ye göre "doğru, doğruların yanılsama olduğunu unutanların yanılsamasıdır" (Ecevit, 2001: 63). Bu görüş, postmodern roman veya anlatıda, gerçekliğin yansıtılması yerine, gerçekliği yansıtan roman yazmanın kurguya katılmasını netice verir. "Postmodernist roman, barındırdığı dünyanın kurmaca olduğunu, içeriğindeki çok güçlü vurgularla belirtir. Bunların en yaygını, kurmaca oluşu bizzat yapının kurgulanıs düzleminin temeli yapmadır. İçeriğin işleyiş düzeniyle onun kuruluş süreci koşut kılınır bu yöntemle. Böylece metnin yazllma süreci aynı zamanda romanın konusu hâline gelir." (Sazyek, 2002: 494). Postmodern sanat anlayışıyla beraber anlatının merkezinde artık konu değil, konunun kurgulanışı yer alır. Gerçek ile kurmaca arasındaki ilişki, sorunsallaştırılarak anlatı yapıbozuma uğratılır.

Postmodern anlatıya uygun olarak birden fazla anlatıcının bulunduğu Fehmi K.'nın Acayip Serüvenleri adlı ikinci anlatıda anlatı kuramıyla ilgili pek çok noktaya temas edilir. Birbirleriyle doğrudan ilişkili olmayan, ancak ortak anlatıcılara ve karaktere sahip çerçeve kurgunun yanı sıra bir iç kurgunun varlığı dikkat çeker. Türk edebiyatında Postmodern anlatının kayda değer ilk örneklerinden olan Fehmi K.'nın Acayip Serüvenleri için Yıldız Ecevit şunları kaydeder: "Türk edebiyatında üstkurmacanın en çarpıcı örneklerinden biri olan Hilmi Yavuz'un Fehmi K. 'nın Acayip Serüvenleri'nde yazar/anlatıcı, metninin kurgusunu nasıl yönlendireceğini meta düzlemden okuruna anlatır." (2001: 98). İroni biçiminde ele alınan anlatı problemi ve kurguya dönüştürülen anlatının kendisi, Fehmi K. 'nın Acayip Serüvenleri'nin asıl kurgusunu oluşturur. Bir anlatı parodisi yazmak için yola çıkılan Fehmi $K$. 'nın Acayip Serüvenleri'nde anlatının nasıl kurgulandığı üzerinde durulur. Anlatıda hemen her unsur, anlatıcı tarafindan anlatıyı kurgulamak için kullanılan birer figüratif olgu, olay ve kahramandırlar:

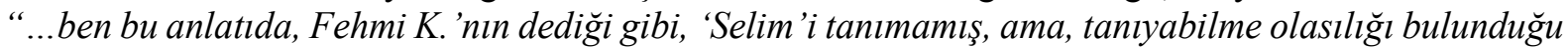
halde tanımamış, tanıyamamış olan biri'yim', ve bir 'anlatı kişisi' olarak betimliyorum onu”' (s. 140). 
Şerif Aktaş, Roman Sanatı ve Roman İncelemesine Giriş’te romanda anlatıcıyı, bakış açısını şu şekilde tanımlar: "Bakış açısı, anlatma esasına bağlı metinlerde vaka zincirinin ve bu zincirin meydana gelmesinde kullanılan mekân, zaman, şahıs kadrosu gibi unsurların kim tarafindan görüldügü̈, idrak edildiği ve kim tarafindan, kime nakledilmekte olduğu sorularına verilen cevaptan başka bir şey değildir." (1991: 84). Ancak modernizm ve öncesindeki romanlarda görülen tekil anlatıcının yerini postmodern anlatılarda çoğulcu anlatıcılar alır. Fehmi K.'nın Acayip Serüvenleri'nde anlatıcı sıklıkla yazma tekniği ve eserin kurgulanışı hakkında bilgiler sunar. Bu anlatıda yer alan küçük olay halkaları, kullanılan mekân, çizilen sınırlı sayıdaki karakterler ile amaç bir kurguyu yani olay örgüsünü anlatmak değil; bu unsurlar üzerinden anlatının yazılış sürecini somutlaştırarak bir anlatı parodisi ortaya koyar. Bunu yaparken de anlatıcı çeşitliliği ile okuyucunun kafasında sürekli soru işaretleri bırakır. Yazar bu durumu "...bu anlatıda kimin yazar, kiminse anlatı kişisi olduğunu bilmediğimi söyleyerek yanitlarım sizi. Bilmediğimi, diyorum; belki siz bütün bu saçmalıklardan kimin anlatan, kimin de anlatılan olduğunu çıkarabilmek ferasetini gösterebilirsiniz. Okuyan, yazandan ârif gerek!..” (s. 156-157) biçiminde ifade ederek hem çoğulcu anlatıcıya hem de anlatıcı ile yazarın ayırt edilemeyişine dikkat çeker. Anlatıda, anlatıcı çeşitlemesi ve anlatıcıların kullandıkları diller dikkat çekici bir çeşitlilik arz eder: "Bir roman vardır, hani kişileri konuşur, ama hangi sözün hangi kişiye ait olduğunu bulgulamak, okura bırakılmıştır. Sözlerle insanlar arasındaki ilişkiyi kurabilmek, bir okuma uğraşı ister, işte öyleydim ben, bu romanin okurlarından biri gibiydim." (s. 67). Postmodern anlatılarda anlatıcinın, öyküyü alışılagelen biçimde anlatmadığını belirten Ecevit, bunu "kurmaca karakterlerinin altını çizerek yap"tıklarını belirtir (Ecevit, 2001: 74).

Hilmi Yavuz'un 1994'te yayımladığg Kuyu; daha önce yayımladığı Taormina ve Fehmi K. 'nın Acayip Serüvenleri'nin içerik ve özellikle anlatıcı bağlamında giriftliğine sahiptir. Bilinçaltına yapılan bir yolculuğu konu edinir. Anlatı kahramanlarından İzzeddin Şadan'ın yinelediği "Hayatımız mülemmâ...” karmaşayı çok güzel ifade eder. Bu ifade sosyal boyut da içerir. Rahim Tarım, 'Hayatımız mülemmâ!..'dan hareketle Kuyu'nun toplumsal mesaj içerdiğini, bu ifadeyi Hilmi Yavuz'un Doğu ve Batı ikilemi yaşayan toplumumuz için kullandığını söyler: 'Yıllarca Batı'nın 'bikr-i fikri' ile Doğu'nun akl-ı pirânesini tezvic etmek gibi bir ütopya peşinde koşan; daha sonra uzun bir süre de geçmişini inkâr etmiş bir anlayışın, hilkat garibeleri doğurduğu bir toplumu, ancak 'hayatımız mülemmâ' gibi bir cümle bu kadar güzel özetleyebilir." (Tarım, 1996: 43)

Hayat mülemmâdır, Kuyu adlı anlatıda anlatı yazmak için gezmekte olan Hilmi Yavuz'un evinin karşısında yapılan otel inşaatında yaşamın muamması adeta somuta dönüştürülür. $O$, yüz katlı olacağ söylenen bu otel inşaatının aslında bir kuyunun bulunması için yapıldığını düşünür. Bir kenti andıran otel, içinde yaşanılan şehir ve toplumdur. Sığ lığı ifade eden otel inşaatı insanların gönüllü hapsi için yapılır: “... Bütün bu kuyu kenti, bu tozlaşmaya yüz tutmuş yatalakları, ... otel ayılarını, Hikmet Benol'ları, firça saçll, popyonlu ve sanki yaşamiyormuş gibi duran yorgun ruhlu krupiyeleri; kitap kurtlarını, mutsuz ve daima tedirgin duran entelektüelleri; her birinden birer Kafka çıkarılabilecek olan suskun banka memurlarını... daha ilâhiri, bütün kenti içine alacak bir kuyu! Bu kuyu-kent! ... Otel bahane, bu kuyuyu bulmak istiyorlar" (s. 175-176). Bu kent, İstanbul'un özelliklerini taşır: "Hilmi Yavuz'un günleri, bu büyük ve yorgun kentte, her şeyin tozlu ve külrengi olduğu bu kentte (bir şiirinde, kentin 'ölüme endekslendiğini' söylemişti!) ve tenha saatlerinde bir kuyuyu aramakla geçti., (s. 167). Hilmi Yavuz, Kuyu'yu metinlerarası bağlamda, İstanbul motifli bir şiiriyle üstkurmacayla ilişkilendirir. İstanbul, mekân olarak bu bileşimin harcı olur.

Küçük bir anlatı olmasına karşın nitelikli postmodern örnek olan Kuyu'da, bu akımın pek çok hususiyeti bulunur. Postmodern anlatıların çoğunda karşılaşılan polisiye romanlara özgü merak unsuru, Kuyu'da da yer alır. Çocuk Hilmi Yavuz'un Siirt'te duyumsadığı ve kimi yerde yaşanmış gibi yansıttılan fantastik unsurlar, anlatının merak ve bilmeceliğine gerçeküstü boyut kazandırır. Neci Bey'in Müstehase Hanım ile yasak aşkına bağlı olarak intiharı, ölümünün kuyuyla ilişkili oluşu; Fehmi K.'nın Acayip 
Serüvenleri ile irtibat kurulmasına neden olan ilgiler Киуи'yu esrarengiz kılar. Anlatı veya romanlara bilmece havası katan postmodern anlatı anlayışında, polisiye romanlara öykünme de vardır.

Üç kurgunun eş güdümlü aktarıldığı Киyu adlı anlatının merkezinde "kuyu” bulunur. Taormina' da bakışımlı kahramanların yerini, burada kuyu motifinin aldığg görülür. Anlatı yazmak için kuyu arayan Hilmi Yavuz, çocukluğunda genellikle kuyuya dair efsaneler dinler. İngiltere ve Almanya'da yine kuyularla bir şekilde ilgili olur ve kuyuya merak salan kişilerle tanışır, bunlardan biri İtalyan kız arkadaşı Theodolinda Barolini'dir. Fehmi K.'nın Acayip Serüvenleri'nin önemli kahramanlarından olan ve bu anlatıda da okuyucunun karşısına çıkan Müstehase Hanım kuyulara merakl1, psikolojik rahatsızlığına kuyu sularından çareler arayan biri olarak sunulur (s. 204).

Kuyu'da imlenen "ölüm" olayı bir yönüyle Hilmi Yavuz cephesinde ergenlik döneminde Müstehase Hanım'a duyduğu cinsel ilginin utancına dayanır. Kuyu'da “ölüm”ün konu olarak ele alınması ve intihar biçiminde ortaya çıkması bu bunalımı yansıtır. Kuyu'nun başından sonuna değin ölümünü anlatacağı anlatıyı yazmak için pek çok kuyu gezen Yavuz'un kendi ölümünü kaleme almasını, Selim Taşıl'dan aldığı ve İzzeddin Şadan Amca'sının 'casebook'u (s. 152) ile ilişkilendirmek mümkündür. "Şimdi kuyudaydı işte, ve orada-olmak yetiyordu Hilmi Yavuz'a. Kuyuya inmek ve anlatı'sını (kendi ölümünü yaşamaya ilişkin bu anlatıyı) orada yazmak ona dayanılmaz geliyordu. Christa Wolf'un Kassandra'da söylediğini tekrarllyordu hep:

\section{Bu anlatıyla ölüme doğru gidiyorum!}

Kuyuya inmek! Belki biraz daha derine inse, kuyunun, onun için ne anlama geldiğini, bilinçdışının derinliklerinden çıkarabilirmiş gibi geliyordu!" (s. 171). Kuyu, bilinçdışıdır; Hilmi Yavuz, yaşamış gibi anlattığı, oysa yaşandığ ş̧üpheli birtakım olay ve kahramanları bilinçdışında kurgular ve zaman zaman bunu gerçekmişçesine okuyucuyla paylaşır. Adı sıkça anılan İbn Mukanna ve onun yaşadıkları bu duruma örnek gösterilebilir. Siirt'te Muhammed Emin'in bahsettiği bu adam yalnız yaşayan biridir ve kuyuların sırrını bilir. En azından Muhammed Emin bildiğini söyler: "İbn Mukanna'nın ne söylediğini anımsamıyor Hilmi Yavuz. Anımsamak için, kuyu gerek, -kuyular, anımsamak için iyidir. (Bon a rappeler diyordu bir filozof-Hegel olabilir mi?) Her neyse, Muhammed Emin ile Halkevi'nin arkasındaki o tuhaf mahallede, İbn Mukanna'nın evini arayıp buldulardı o yaz sonrasının yasemin saatinde, sarı otların bürüdüğü bahçesinde, kuyudan çıkrıklı acı su çeken sakallı adamı (İbn Mukanna bu muydu?) gördüğ̈̈nde anımsıyor: Anımsamayı anımsıyor -neyi anımsadığını değil!"” (s. 186).

Postmodern anlatıların önemli özelliklerinden biri de fantastik unsur ve motiflerden yararlanılmasıdır. Fantastik unsurlar, anlatı ve romanın kurgusuna göre farklılık gösterir. Todorov, Fantastik adlı kitabında bu kavramın uyandıracağı tereddüde bağlı olarak gerçekleştiğini belirtir: "Fantastik üç koşulun yerine gelmiş olmasını gerektirir. Metin öncelikle okuyucunun, öyküdeki kişilerin dünyasını canlı kişilerin yaşadiğı bir dünya olarak görmesini ve anlatılan olaylarla ilgili olarak doğal bir açıklama ile doğaüstü bir açıklama arasında karasızlık duymasını sağlamalıdır. Sonra, bu kararsızlık bir öykü kişisi tarafindan da hissedilmelidir; böylece okuyucunun görevi bir kişiye verilmiş olur, aynı zamanda da 'kararsızlık' metin boyutunda ortaya konduğu içindir ki yapıtın izleklerinden bir haline gelir; saf bir okumada gerçek okuyucu öykü kişisiyle özdeşleşir. Son olarak, okuyucunun metin karşısında bir tavır takınması gerekir ..." (Todorov, 2004: 39). Bir anlatı örneklemesi olarak Kuyu'da bu özellikler doğrudan bulunmasa dahi birtakım garip ve olağanüstü kişiler, olay ve söylentiler yer alır. Bunların çoğu kuyu merkezli olarak Hilmi Yavuz'un çocukluğunda, Güneydoğu kenti olarak anılan Siirt'te yaşanır ve duyulur. Büyükbabasının konağındaki acı ve tatlı su kuyuları, arkadaşı Muhammed Emin'in anlattıkları ve onunla İbn Mukanna'nın evine gitmeleri anlatının fantastik boyutunu olușturur. Anlatılanlar, okuyucuda gerçek ve gerçek dışılık yönünde izlenimler uyandırır. Hilmi Yavuz'un acı ve tatlı oluşundan dolayı cennet ve cehennem olarak tanımladığı konaktaki kuyulardan birine düşürdüğü topu çıkarmaya çalışan Pembo abla top yerine ölü bir kedi çıkarır. Yavuz'un bu olayı Muhammed 
Emin'e anlatırken gördüğü kedinin Danyal'ın oğlu Hasip olabileceğini belirtmesi anlatıya fantastik boyut kazandırır. Yazar bu dinî ve efsane içerikli hikâyeyi Almanya'da yerleşik bir Türk işçisinin bant kaydından anlatıya aktarır (s. 199-201). Nitekim daha sonra o kuyudan Neci Bey'in cesedini Pembo Abla, Hilmi Yavuz ve Muhammed Emin'in çıkarması, ölü kedi olayıyla bakışımın yanı sıra anlatılanlar hakkında okuyucuda şüpheler uyandırır (s. 214).

Fantastik unsurlardan gerçeklik ve gerçek dişılık konusunda tereddüt duyulması gerektiğini söyleyen Todorov, bu ikilemin herhangi birine yanıt bulunduğunda veya ihtimal verildiğinde fantastiklikten uzaklaşılacağını düşünür. Fantastik olan şeyin kararsızlığa dayandığını söyleyerek kararsızlığı okuyucu ile birlikte kahramanın da yaşaması gerektiğini belirtir: "Fantastik, kendi doğal yasalarından başka yasa tanımayan bir öznenin görünüşte doğaüstü bir olay yaşadı̆̆ı kararsızlıktır." (2004: 31). Bu kararsızlığı okuyuculara duyumsatan Hilmi Yavuz'un kendisi de anlatıda yer alır ve Muhammed Emin ile İbn Mukanna'nın evini bulurlar. İbn Mukanna'yı uzun süre izleyen Hilmi Yavuz, daha sonra gördüklerinden şüpheye düşer ve sadece anımsadığını sanır: “...sarı otların bürüdüğ̈̈ bahçesinde, kuyudan çıkrıllı acı su çeken seyrek sakallı adamı (İbn Mukanna bu muydu?) gördügünde anımsıyor: Anımsamayı anımsıyor -neyi anımsadığını değil!’” (s. 186). Anlam karmaşası ve dil oyunu ile desteklenen bu zan, Hilmi Yavuz'un yaşanmış gibi anlattığı bilinçdışındakileri kurgulamasının yanı sıra gördükleri karşısında kararsızlığını gösteren fantastik bir durumdur.

Hilmi Yavuz postmodern anlatı örneği olarak Taormina, Fehmi K. 'nın Acayip Serüvenleri ve Киуи adlı anlatılarını bilinçli bir şekilde kaleme alır. Dilek Doltaş'ın "başarılı birer postmodern örnek" (1996: 20) olarak andığı bu anlatılar, basit olay örgülü olmalarına karşın postmodern unsurlar açısından zengindir. Anlatıların bu yönüyle ilgili olarak Hilmi Yavuz şunları kaydeder: "Romanın benim harcım olmadı̆̆ını anladım. Ama yüz sayfalık, yüz yirmi sayfalık kısa anlatılar yazabilirim. Bunları eğlenceli postmodern metinlere dönüştürebilirim. Gerek edebiyatı gerek yazarı tiye alarak bunları yapabilirim. Taormina, Fehmi K.'nın Acayip Serüvenleri ve Kuyu bunun sonucudur.” (2006: 166).

Hilmi Yavuz, anlatılarında yansıtmaci/geleneksel, modern roman anlayışlarını postmodern yaklaşıma uygun bir ironi ile alaya alır. İroni, Taormina'da postmodernizmin, metinlerarası ilişkisi anlayışına yöneliktir. Dolayısıyla bu anlatısında, metinlerarası ilişki ile aldıklarına bakışımlı karşılıklar bulur. Anlatı ve romanlardan hareketle kaleme aldığı bir parodi örneği olan Fehmi K.'nın Acayip Serüvenleri'nde ise modern edebiyatın tercihi olan nitelikli okuyucu kavramıyla dalga geçilir ve modernizmin seçkinciliği eleştirilir.

Ü̧̧ Anlatı'nın en önemli özelliklerinden biri de felsefî boyutlu oluşudur. Anlatılarda Aristo'dan Derrida'ya uzanan filozoflar listesinde onlara ve görüşlerine dair alıntı, göndermeler yer alır. Anlatıda görülen ironi; felsefeye ve özelde kuramlara dair olan kesitlerde ön plana çıkar. Hilmi Yavuz, anlatıların bu yönüyle ilgili olarak Taormina ve Fehmi K.'nın Acayip Serüvenleri bağlamında şunları kaydeder: “'Taormina' ve 'Fehmi K. 'ya gelince, iddialı bir şey söyleyeceğim: Bu iki anlatl, Aydınlanma'dan bu yana Rasyonalizm adına temellendirilen, verili ne varsa, neredeyse tümünü yerle bir etmek amacıyla yazılmışlardır. Akıl'a karşı İroni'yi çıkararak! Nietzche'yi biraz değiştirerek söylersek, Akal, sadece ya evet ya hayır der; oysa Ironi hem evet hem hayır, der, çünkü!’" (1997: 216).

Postmodern anlatılarda, kurguların birçoğunda yazar, anlatı/roman yazma uğraşını metnin merkezine koyar ve kendisini de anlatının bir karakteri olarak konumlandırır. "Yansitmacı romanın didaktik kimlikli yazar-anlatıcısı, bu kez anılan işlevini yitirmekle birlikte, romana geri dönmüştür artık. Yazar, romanını hem yazmakta hem de kurmacasının içinde, kendine figüratif anlamda yer açmaktadır. Zira postmodernist romanda yazmak ve yaşamak iç içe geçmiştir." (Sazyek, 2002: 498). Hilmi Yavuz'un her üç anlatısında da bir yazma uğraşısı vardır. Taormina' da Yusuf Horoz; Fehmi K. 'nın Acayip Serüvenleri'nde yazar anlatıcı olarak Hilmi Yavuz; Kuyu'da ise anlatı yazma için kuyuya inen kişi Hilmi Yavuz'dur. 


\section{Üstkurmaca}

Sosyal, kültürel ve bilimsel alanlarda gerçeklik algısının değişimi ile beraber edebiyat özneye ve nesneye olan bakışını değiştirir; artık önemli olan konu değil, edebiyatın/yazma eyleminin kendisini anlatması olur. "20. yüzyıl edebiyatının bu yeni doğasında yazar/anlatıcı yalnızca kurgulamıyor, metni nasil kurguladiğl konusunda malzeme olarak el alıp onu ikinci bir düzlemde yeniden kurguluyordur. Yazarın/anlatıcının/okurun hep birlikte metnin içinde yer aldıkları, giderek birer roman kişisine dönüştükleri bir ortamda konu, metnin neyi anlattı̆̆ değil, nasıl kurgulandı̆̆ıdır artık” (Ecevit, 2011: 98). Postmodern romanlar olayları irrasyonel, birbirinden uzaklaşmış/kopmuş, düzensiz ve tam bir kaos olarak kurgular. $\mathrm{Bu}$ tür romanlar okunduğunda akılda genellikle olay örgüsü kalmaz; bu nedenle postmodern metinde okuyucu, metni her okumada farklı bir biçimde anlayıp yorumlayabilir. Sonuç itibariyle modern romanın kalıplaşmış, rasyonelleşmiş, belli kurallara ve ilkelere dayanan roman tekniğinden kaçış; romanı, postmodern romanın eşiğine getirir.

Üstkurmaca, postmodern edebiyatın en temel kurgu ögelerinden biridir. Üstkurmaca "yazma ediminin kurmaca metnin içinde kurgulanması demektir" (Ecevit, 2008: 142). Bu, yazarın metnini nasıl öykülediğini, hangi kitaplardan etkilendiğini, hangi otobiyografik yaşantısını kurmaca düzlemine aktardığını o metnin içinde anlatmasıdır. Başka bir ifadeyle "Üstkurmaca (metafiction), en bilinen tanımıyla "roman teorisini" roman yazma tekniği içerisinde gösterme işidir" (Waugh, 1996: 2). Oluşan bu yeni roman estetiğinde kahraman ve içerik anlatıda birincil unsur olma özelliğini kaybeder, kurgusal metindeki yapı parçacıklarına döner. "Üstkurmacayı irdelemek, romana kimliğini kazandıran hususların farkına varmaktır” (Waugh, 1996: 2). Yazar bununla kurmaca ve gerçeklik arasındaki ilişkiyi belirginleştirerek metnin kurmaca yapısına bilinçli ve sistemli bir şekilde dikkat çekmeyi amaçlar.

Üstkurmaca anlatım, Waugh'un (1996: 100) ifadesi ile okuyucuya, zihninde "alternatif dünyalar" kurulabileceği farkındalığını gösterir. $\mathrm{Bu}$ metinlerde yazarın yeni bir alternatif dünya kurarken en çok yararlandığı unsur "dil" olur. Yazar elindeki insan, zaman, mekân ve hikâye gibi malzemeleri ancak dil vasıtası ile bir araya getirir ve kurmaca gerçeklik sunar. Üstkurmaca, usta bir dil oyunudur ve dil üstkurmacada ontolojik boyutta ele alınır. "Ö̈ellikle çağdaş üstkurmaca, romanın ve gerçek dünyanın kurulmasındaki sistem/çerçeve prosedürlerini incelemeyi bir problem olarak ön plana çıkarır. Tabii ki onun yarattı̆̆ ilk problem 'sistemin/çerçevelemenin ne olduğu'dur. Gerçeği kurmacadan ayıran yapı nedir? Çerçeve bir kitabın ön ve arka kapaklarından, perdenin açıllp kapanmasından, başlık ve sondan daha mı fazladır?" (Waugh, 1996: 28). Bir yönüyle üstkurmaca anlatılar, gerçek hayatın da roman gibi çerçevelerden/halkalardan oluştuğunu; insanın, çerçevenin neresinde olduğunu ve bu çerçevenin nerede başlayıp nerede bittiğini bilmenin mümkün olamayacağını bildirir.

Üstkurmaca anlatıda zaman kavramı farklı ontolojik tabakaların metafizik dokusu içinde bilinen anlamını yitirir. Böylece zaman unsuru tabakalar arasında belirsizleştirilir ve metin çokkatmanlı bir yapıya ulaştırılmış olur. Metinde "kurmaca ile gerçek"e iç içe geçmiş tabakalar görünümü verilir. Buna bağlı olarak romanda okuyucunun kesin olan bir anlam çözümlemesi imkânsız hâle gelir. Üstkurmaca “...kurguyla gerçek arasindaki bağı modernist ya da post-modernist bağlamda sorunsallaştıran, yazarın otoritesini sorgulatmak için anlatıcıyı kllıktan kulığa sokan, gerçekçi anlatım yerine Baudrillard'ın hipergerçeklik diye tanımladı̆̆ sürrealist, fantastik ya da büyülü gerçeklik tekniklerini benimseyen, nedensellikle oynayarak düsle uyanıklk arasındaki sinırları bulandıran, gene nedenselliğin bozulması uğruna grotesk ve düşsel dönüşümlere yer açan; zaman-mekân olasıllıklarını hiçleyen, referans çerçevelerinin nesnel dünya değil yazı olduğunu savunan, anlamın sınırlarının bu çerçevelerle ve keyfi olarak belirlendiğini ileri süren, kısaca her şeyin mümkün olduğu bir evren yaratan, oyunbaz anlatılar" (Ören, 2016: 142-143) ifade edilir. 
Üstkurmaca romanda okuyucu, anlatının nerede başlayıp nerede bittiğini ya da hangi zamanda başlayıp hangi zamanda bittiğini fark edemez. Çünkü üstkurmaca romanda zaman ve mekân farklı bir düzlemde ele alınır. Anlatıda zaman ve mekân unsuru somutlanmak yerine soyutlanarak bilinçli ve sistemli bir şekle, kaosa/karmaşaya sürüklenir.

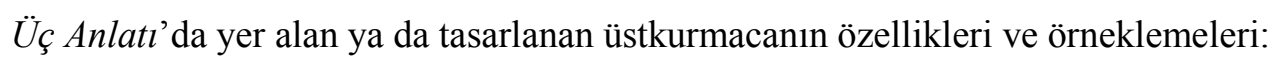

\section{Kurmaca ve Gerçekliğin İç İçeliği}

Üstkurmaca metinlerde gerçek ve kurmaca arasındaki sınırın kalktığı, okuyucunun şaşırtıldığ 1 , yazarın kimi zaman okuyucuyla sohbet ettiği, romanın başından sonuna kadar bir gizemi sürüklediği, anlatının bir kurmaca ve oyun olduğu gösterilmeye çalışılır. Aynı zamanda okuyucunun algılarıyla âdeta oynanır, renkler ve sesler ön plana çıkarılır. Yazarlar “...kendi zihin(lerini) pırıl pırıl tutarken okuru(nu) aldatmaya ihtiyaç duyar..." (Eco, 2011: 19). Ve bütün bu unsurlar romana bilinçli bir şekilde işlenirken bir yandan da okuyuculardan bu unsurları keşfetmeleri beklenir.

Üstkurmaca metinde yaşam ile kurmaca iç içedir. Bu nedenle yaşam, bir yazma eylemidir. "Postmodern anlatıda gerçek ile kurmacanın iç içe, geçirgen bir yapı içinde sunulduğu bilinmektedir. Gerçeklik düzleminde sergilenen bir olay ya da kişinin serüveni metinde kurmaca düzlemine kayabilir. Gerçek olay ya da figür birdenbire rüyaya, bir hayale, bir fanteziye ya da bir masala dönüşebilir veya anlatı içinde buharlaşabilir. Bu bağlamda gerçeklik ile kurmaca birbirine karşıt, birbirini iten veya birbiriyle çekişen kavramlar değil, birbirinin içinde eriyerek hoş bir duygu ve etki birakan kavramlardır" (Işıksalan, 2007: 447). Anlatıda gerçek olan ile olmayan arasında bir ayrım yapılamaz hâle gelir. Artık çağdaş romanda gerçeklik unsuru dış somut/gerçek dünyada değil, iç dünyada ve bilinçdışında aranır. Bu bakımdan çağdaş roman somuttan soyuta, bilinenden bilinmeyene giden bir hâl alır.

Üstkurmaca anlatılar gerçekliği yansıtmaz, gerçeklik okuyucuya yalnızca sezdirilir. Roman kahramanları arasındaki belirgin özelliklerin ortadan kalkması anlatıya yeni bir biçim getirir: Bu yeni biçim ile "Okurun kafası bilinçli olarak karıştırılır" (Waugh, 1996: 37) ve yeni soru işaretlerinin oluşmasına zemin hazırlanır. Böylece okuyucu, neyin gerçek neyin düş olduğu konusunda ikilem yaşar.

\section{a) Taormina}

Anlatıda "gerçeklik" ile "düş" sözcüklerinin çoğunlukla bir arada kullanılması dikkat çeker. "Taormina'da objelerin sürekli birbirleriyle yer değiştirdikleri" (s. 31) vurgulanarak gerçek ile kurmacanın iç içeliği belirtilir. Taormina'da “...hüzü̈n de sevinç de uzamsal değil, zamansal olarak birbirlerinden ayırt edilebilmekteydiler. Hüzünle sevinci aynı anda yaşamak olası değildi; ama aynı uzamda yaşamak olastydl. Hüzünle sevinç birbirlerini bütünleyen bir benzer çift (bir çift eldiven gibi) değil, birbirlerinin yerini alan iki tek eldiven gibiydiler..." (s. 33). Üstkurmaca anlatılarda sıkça görülen birbirinin yerine geçme, eldiven örneği ile ortaya konmaya çalışılır. Bu durum, anlatıda "metonimi" kavramıla izah edilir. Nitekim Taormina'da objeler, metonimi kavramının anlamına uygun olarak sıklıkla birbirleriyle yer değiştirirler.

Anlatıcının "Neden aynaya baktı̆̆ımızda să̆ yanımız solda, sol yanımız să̆da görünür de, üst yanımız altta, alt yanımız üstte görünmez? Aynalar dikey bölünmede bir yer değiştirmeyi gerçekleştiriyor da, neden yatay bölünmede bir yer değiştirmeyi gerçekleştirmiyor?” (s. 11) diye sorması aslında anlatının yazılma sürecindeki bakışım ile ilgilidir. Bu sayede anlatıcı gerçek ile kurmacanın iç içeliğini ve okuyucunun şu an elinde tuttuğu bu eserin aslında kurmaca bir eser olduğunu vurgulaması içindir. Dolayısıyla yazının/edebiyatın, dış dünyadaki gerçekliği/gerçeği olduğu gibi yansıtan bir ayna olmadığı gerçeği vurgulanır. "Taormina'da tekdüzelik, bakışım olarak ortaya çıkar, öte yandan bir şeyin bir yanını görmek, öteki yanını da görmek anlamına” gelir... ve parça bütünün yerine geçer!... (s. 24). 
Taormina'nın bakışımlı kurgulanışı, anlatının üstkurmaca boyutunu oluşturur. Postmodern anlatının en önemli özelliği olan üstkurmacada, gerçek yaşam ve anlatı kurgusu birbirleriyle ilintilidir. "Somut yaşam ve kurmaca metnin bir araya getirilmesi, birbiriyle çakıştırılması, aradaki sınırların yok edilmesi, üstkurmaca düzlemin ana özelliğidir." (Ecevit, 2001: 105). Bakışıma dayalı olarak kurgular Taormina'da mekân ve daha çok da olay düzleminde olmak üzere iki şekilde gerçekleşir. Yazarın da ifade ettiği gibi Taormina'da "gerçeklik yanıltıcı" (s. 12) bir şekilde kurgulanır. Anlatı kahramanlarının bakışımlı kurgulanışları, anlatıcının gerçek yaşamıyla ilişkilendirilmesi eserin üstkurmacasını tamamlayan diğer hususiyetidir.

Hilmi Yavuz, kendi yaşamından mekânlarla birlikte kişileri, adlarıyla birlikte kahraman rolüyle anlatılarına taşır. Meslek ve uğraşılarıyla örtüşen nitelikte anılan bu kahramanların ilki, gerçek dünyada arkadaşı Alaadin Eser'dir. Sahaf olan bu kişi Taormina'da da sahaftır. Fehmi K.'nın Acayip Serüvenleri'ndeki Fazilet Dadı, Hikmet Yavuz'un Diyarbakır-Çermik kaymakamıken Hilmi Yavuz'un dadılığını yapan kızdır. Fazilet Dadı, Hilmi Yavuz'un bebek ve çocukluğunda Vecide Yavuz'un en büyük yardımcısı olur (Yavuz, 2006: 16). Kuyu'da çocuk Hilmi Yavuz'a birçok efsane ve hikâyeler anlatan Muhammed Emin, onun 1952-1953 yazlarını geçirdiği Siirt'ten arkadaşıdır. (Yavuz, 2005: 17$18)$.

$\ddot{U} c ̧$ Anlatı'da Kahraman konumundaki karakter, çoğu zaman Hilmi Yavuz'un kendisidir. Anlatılardaki yoğun kurgusal örgü, postmodern romanın özelliklerinden olsa bile Kuyu'da İzzeddin Şadan'ın sıklıkla tekrarladığı 'hayatımız mülemmâ' söylemi, Hilmi Yavuz'un bilinçaltıdır ve anlatılara yoğun kurgusal örgüler biçiminde yansır. "Mülemmâ" aynı zamanda insanların ortak yaşam öykülerine ya da yazarların/şairlerin eserlerine bir göndermedir ve bu kavram, yazarın anlatıda cennet ve cehennem kuyusu olarak adlandırdığı Doğu ve Batı edebiyatı arasındaki gelgitlerini ifade eder: "İkiz bir ömrü yaşıyordu. Cennet ve cehennemi beraberinde gezdiriyordu. Bu iki haddin arasında, uçurum kenarlarında şiddetli uyanışlarla dolu bir somnambül hayatı vardı (...)” (s. 173). Postmodern anlatı yazarları konuya değil kurguya önem verdikleri için aynı konuyu farklı şekillerde tekrar işlemekte sakınca görmemişlerdir. Yeryüzünde işlenmemiş bir konu kalmamışsa o hâlde yapılması gereken şey, aynı konuyu farklı şekillerde tekrar işlemektir. $\mathrm{Bu}$, metinlerarası düzlemde olabileceği gibi metnin yazılış sürecinin ön plana çıkarıldığı üstkurmaca düzlemde de kendini gösterir.

Hilmi Yavuz'un otobiyografisinden izler taşıyan Taormina, hayalini kurduğu mekândır. Kendisi gerçek dünyada yaşayan biridir. "Doğrusu ya, aşırı kuşkucu biriyim ben. Geçenlerde, geceyarısı bizim evin bulunduğu sokakta canhıraş köpek havlamaları duyuldu (Bu, "Taormina'daki sokak elbette!). Eşim sevgili eşim, köpek havlamaları üzerine uyanmış, beni de uyandırdı: ... Şimdi, asıl anlatılması gereken şeyi anlatmadı̆̆ımı anımsadım birden: Neyi anlatmadı̆̆ımı anımsadım: Kimdim ben? Ve neden bunları yazlyordum? Bakın, küçük bir memurum ben; ...” (s. 37). Yazar, özel yaşamı ile yazmakta olduğu kurmaca yaşamı birleştirir, gerçek ile kurmacayı iç içe sunar. Gerçek yazar Hilmi Yavuz ile otobiyografik bir anlatı yazarı olan Yusuf Horoz'un yazdıkları ve yaşadıkları pek çok açıdan birbirine paraleldir. Realitede her ikisinin de anlattıkları gerçek ile kurmacanın farklı şekillerde algılanması ve sunulmasıdır. Bu bağlamda anlatıda gerçek ile kurmaca mekân arasındaki sınır zayıflar ve bilinçli bir şekilde düzlemler arası geçişkenlikler yaşanır: "Size daha önce de söylemiştim bunu! ... Doğrusu ya, size daha önce söylediklerimi mi söylemedim diye anımsadım, yoksa söylemediklerimi mi söyledim diye anımsadım, bilmiyorum. Aslında, aralarında sadece cansıkıcı olmak ya da olmamak bakımından fark var, bana göre; hepsi o kadar!” (s. 36).

Yusuf Horoz adının ilk harfleri ile Hilmi Yavuz'un adının ilk harflerinin aynı olması bilinçli yapılan bir tercihtir. Zira otobiyografik tarzda yazılan bu eser, kurmaca ile gerçekliğin birlikteliğini gösterir. Emekli kaymakamlardan İsmail Asım Horoz'un oğlu olan Yusuf Horoz'un Taormina'da anlattıkları hayal-gerçek karışımı olsa bile kendi otobiyografisidir. Anlatının çekirdek vakası, Taormina'da yaşadığına inanan ve kendini önce felsefeci daha sonra romancı olarak düşleyen Yusuf Horoz'la röportaj yapmak için Le M. gazetesinin muhabiri Christian D.'nin Fransa'dan Taormina'ya 
gelmesidir. Yetmiş dokuz sayfalık anlatının altmış ikinci sayfasında, bu gazetecinin gelmesi ve Yusuf Horoz'un ona anlattıkları, Taormina başta olmak üzere bakışımlı imge mekân ve karakterler bir bir anlam kazanır: "Christian D. 'a, asıl önemlisi, otobiyografik bir roman yazacağımı, bütün hazırlıklarımı buna göre yaptı̆̆ımı da söylemeli değil miyim? Bu romanda, şeyden söz etmeyeceğim kesin: Felsefe tutkumdan! Anımslyorum. Bir zamanlar felsefeci olmak istemiştim. Bunu anlatmamaliydım. Komik şeyler yazdım, çünkü. Sanki bir kent bulmuşum da, sözcüklerle imgeler arasında bir bakışım varmış da, -ya da buna benzer şeyler... Bir felsefekurgu romanı yazmanın yolu, sanırım böyle şeyler yazmaktan geçmiyor-geçmemeli de!... Bulduğum kentin adının 'Taormina' ya da 'Valdrada' olmasiysa hiç önemli değil. Asıl önemlisi, bu tür ipe sapa gelmez yazıların benden, Yusuf Horoz'dan önce, bazı yazarlarca yazılmış olmasıdır. Ben, başkalarının yaptıklarını yineleyecek bir yazar değilim elbet. Özgün bir yazarım ben." (s. 71). Taormina, Yusuf Horoz'un otobiyografik olarak yazmaya başladığ romanda hayalini kurduğu mekândır ve bu mekân postmodern söylemin temel tekniklerinden olan üstkurmaca tekniğiyle okuyucuya sunulur.

Yusuf Horoz'un Christian D.'ya anlatmadan önce yazdıkları birbirleri ile tamamen bakışımlı mekân ve olay kurgularıdır. Coğrafik olarak gerçeklikleri olsa bile Taormina ile ilgili kaydedilenler imgeseldir. İtalya'nın Sicilya yarımadasında bir kent olan Taormina'nın anlatıdaki imge kentle, isim benzerliğinden başka doğrudan bir ilişkisi yoktur. Otobiyografik bir roman yazmakta olan felsefe tutkunu Yusuf Horoz, burayı felsefe kurgu amaciyla bilincinde tasarlar. Onun felsefeci kimliğiyle kurduğu kent ideasıdır Taormina. "Ben, 'Taormina'yl, felsefeci kimliğimle idea olarak inşa ediyordum." (s. 41).

Yusuf Horoz, Taormina adlı anlatısını oluşturan unsurlara arkadaşı Erkut'la rastlar. İlkinde, Kıztaşı'nı beyaz bir yelkenliye benzetirler. Viyana'da dolaşırken bir antikacı dükkânın vitrininde rastladığı fildişinden yapılmış küçük fil heykeller diğer ideası olur (s. 71). Ona bu hayalleri kurduran yazar, Hilmi Yavuz'dur. Postmodern anlayışa uygun olarak kurmaca biçiminde anlatıya giren bu öykülerin gerçek ya da hayalî oluşlarının belirtilmeyişi bu akımın esere yansımasından ötürüdür. Ayrıca Kıztaşı'nın görüntüsü ve Viyana'da vitrinde görülen fildişinden yapılan heykeller, Taormina'da sık sık bahsi geçen saray kapısına giden yolda sağlı sollu yerleştirilen beyaz fil imgeleri ve Taormina'nın o penceresinden görülen yelkenlileri oluşturur, böylece anlatıda gerçek ile kurmacanın iç içeliği de gözler önüne serilir.

Diğer taraftan Taormina'da Hıtay’a sefere çıkan Gıyaseddin adındaki kişi de gerçek hayatta yer edinip anlatıya dâhil edilen bir kahramandır. Gıyaseddin, Yusuf Horoz'un arkadaşı Erkut ile Fatih'te ortak tanıdıkları olan bir seyyar gazete satıcısıdır. Gazete tezgâhı önünde Kıztaşı'nı seyreden Yusuf Horoz, bu taşı beyaz yelkenli olarak düşünür: "Sicak yaz ikindilerinde tezgâha vuran güneş çoktan çekip gitmişken, uzaktan Kıztaşı'nı bir beyaz yelkenliymiş gibi düşünmek (burada 'düşünmek', 'hayal etmek'le eş anlamlıdır) müthiş hoşuma gidiyordu." (s. 68). Bu beyaz yelkenli, Taormina imgesine vücut vermede belirleyici rol oynar. Tıpkı Viyana'da antikacı dükkânında rastladığı fil heykelciklerinin, Hoca Gıyaseddin Nakkaş'ın Hıtay seferini anımsatması gibi “Yaşamımın en önemli dönüşümlerinden birini gerçekleştirmeme neden bu mutlu rastlantıdan elbette -ve öncelikle söz etmeliyim. Bu heykelcikler on taneydi (yoksa on bir miydi?) ve birbirinden ayırt edebilmelerine olanak yoktu. Sanki bir kalıptan çıkmış gibiydiler ve ancak uzamda kapladıklart yerden dolayı birbirlerinden ayrllabilirlerdi... Nitekim daha sonra da, kim bilir kaç kez, o filcikleri seyretmeye gittim ve her keresinde bu filcikler imgelemi klşkrtan gizemli bir aura buldum." (s. 71-72). Yusuf Horoz'un Viyana' da gördüğü fil heykelcikleri aslında Hoca Gıyaseddin Nakkaş'ın Hitay seferini anlatan “Acaib'ül Letaif”'ten bir benzetimdir. Bütün bu benzetimlerle yazar, bir bakıma okuyucunun bu olaylar arasındaki bağıntıyı çözmesini ister ve onun dikkatini ölçer. Postmodern anlatılarda yazar, okuyucudan yapmış olduğu dil oyunlarını fark etmesini ve metindeki birtakım göndermeleri anlamlandırmasını talep eder.

Görüldüğü gibi Yusuf Horoz, kendini Taormina' da duyumsadığı bir gün pencereden gitmekte olan yelkenlileri görüp, 'yelkenliler' der. Gördüğünün yelkenli değil metonimi olduğunu söyleyen 
Gıyaseddin adlı kişi, imgelemindeki kahramanlarla aynı adı ve özellikleri taşır. Anlatıda ise Taormina'ya gelen delegasyon heyetinin başında Gıyaseddin adlı biri vardır.

\section{b) Fehmi K.'nın Acayip Serüvenleri}

$\ddot{U C ̧ ~ A n l a t ı ~ p o s t m o d e r n, ~ k u r m a c a ~ b i r ~ m e t i n d i r . ~ H i l m i ~ Y a v u z ~ p o s t m o d e r n ~ a n l a t ı l a r d a, ~ a n l a t ı n ı n ~ b i r ~}$ kurmacadan ibaret olduğunu yineleyip dursa da, anlatının içinde gerçek kimliği yer edinmekten sakınmaz, böylece bilinçli olarak gerçek ile kurmacanın sınırları belirsizleştirilir; kurmaca ile gerçek arasındaki bağıntı sorunsallaştırılır. Yazar, gerçeklik ile kurmacayı harmanlayarak bir yazın kuramı oluşturur. Yazın kuramı veya yazma tekniği hakkında bilgi sunmanın yanı sıra edebiyata dair sorunları tartışarak romanın yazımına yönelir: "Anlatı yazarının kendi büyükbabasına ilişkin olarak anlattıkları, Prens Seyfedddin'in başından geçmiştir... Anlatı yazarı, bize bir akrabasından dinlediklerini, büyükbabasına mal ederek anlatıyor. Dolayıslyla gerçeklik, özne değiştirerek 'kurmaca' oluyor!

\section{Buyurun size bir Yazın Kuramı!}

Ayrıca, anlatı da, tarih gibi, tekerrürden ibarettir, de diyebiliriz: Önce Gerçeklik olarak, sonra Kurmaca olarak!.. Üstelik hiç kimse romanın bittiğini, ve romanın bittiği yerden de anlatının başladiğını görmüyor; - ya da ne bileyim görmek istemiyor..." (s. 123). Yazar, aslında yazın dünyasında anlatılanları, çoğu zaman tarih gibi tekrar ettiğini belirtir. Çünkü romanda anlatılanlar, gerçek hayatta yaşanılanların bir nevi tekrarıdır. Gerçek yaşam ile kurmaca yaşam birbirine o kadar benzemektedir ki bu benzerlik yalnızca şahısların yer değiştirmesi ile ayrılmaktadır. Birbiri içine geçen bu benzerlik, kimi zaman hangisinin gerçek, hangisinin gerçeklikten üretilen kurmaca olduğu rahatlıkla anlaşılamamaktadır.

Aynı şekilde Selim Taşıl'ın da yazın kuramı hakkındaki düşüncelerine yer verildiği görülür: "Anlatı, gerçekliğin öznesini değiştirerek onu kurmaca kılar. Ayrıca anlatı, Tarih gibi, tekerrürden ibarettir de diyebiliriz: Önce Gerçeklik olarak, sonra Kurmaca olarak... Al sana bir Yazın Kuramı, diye düşünüyor Fehmi K.” (s. 129). Sonuç olarak Hilmi Yavuz'un kaleminde gerçeklik, özneler aracılığıyla kurmaca hâline dönüşür ve gerçeklikle kurmaca, hayal ile hakikat arasındaki şeffaf bağıntı, üstkurmaca düzlemde somutlaştırılarak incelikli biçimde işlenmiş olur.

Ayrıca yazar, anlatıdaki kahramanlarını genellikle gerçek yaşamdan seçtiğini ifade ederken bazı kahramanlarının da yalnızca kurmaca karakter olduğu bilgisini verir. Romanda İzzettin Şadan Bey ile Müstehase Hanım evlidir ve Selim Taşıl da Müstehase Hanım'ın ilk evliliğinden olan çocuğu olarak anlatıda yerini alır. Yazar, bu anlatısını oluştururken gerçek yaşam öyküsünden pek çok anıya anlatısında yer verdiğini vurgular; ancak Selim Taşı1'ı ilk kez bu anlatıda gördügünü belirtirken Selim Taşıl'ın aslında kurmaca bir karakter olduğunu ifade etmiş olur: “... Kalamış'ta geçen yillarımızda, yani, İzzeddin Şadan Beylerle çok sıkıfikı olduğumuz yıllarda Selim Taşıl da, kardeşi de hiç ortalarda görünmemişlerdir -belki de, babalarıyla birlikteydiler o yıllarda! Dolayısıyla, benim Selim Taşıl ile gerçek yaşamda karşılaşmışlığım yoktur; onu sadece bu anlatının asal kişilerinden biri olan Fehmi $K$.'nın arkadaşı, yani, ne yalan söyleyeyim, ancak bir anlatı kişisi olarak tanıyorum ... gerçek yaşamda tantyor olabilme olasıllğı olan birini, bir anlatı kişisi olarak betimlemek, bana bu anlatının yazarı olarak, çok kışkırtıcı gelmiştir." (s. 139-140) Yazar, Selim Taşıl'ı tamamıyla kurmaca bir karakter olarak anlatısına eklediğini belirtir.

Fehmi K.'nın Acayip Serüvenleri'nde çoğulcu anlatıcı yöntemiyle gerçek ile kurmacanın iç içeliği dikkat çeker ve bu durumu yansıtan karakter betimlemelerine sıkça rastlanır. Anlatıcı kimi yerde kendini anlatıya katmakla kalmayıp tanıtır. Bu bahislerin çoğu, söz konusu eserde okuyucuyu Hilmi Yavuz'a götürür: “...bırakalım Fehmi K. 'yı, Selim Taşıl'ı, valdesi Müstehase Hanımı... Anette'i ve İzeddin Şadan Beyi, ben size kendimi anlataylm.... Efendim, ben, örneğin, bir sabah uyansam, komodinin üzerinde Bezukhov'un hiç gözlüklerini mi bulurum? Olur mu öyle saçma şey? Ben, olsa olsa, kendi gözlüklerimi bulurum orada. Olmazsa, Nuran'ın gözlükleridir, ya da Acü'nün (Ayşe'nin) 
gözlükleri... Ben de içlerinde olmak üzere, Nuran da, Ayşe de yaşayan kişilerdir. Benim şu anda yazmakta olduklarımdır onlar; gerçeklikte olan kişilerdir. Dolayısıyla, bu, şimdi okumakta olduğunuz anlatının, gerçek kişilerden söz eden bir anlatı olmaya başlaması demektir. Her ne kadar gerçek kişilerden söz eden anlatıların, kesinkes, gerçekliğe bağıml olması diye bir kural yoksa da, bağımlı olmaması diye bir kural yoktur!" (s. 113). Metinde geçen Nuran, bilindiği üzere 1992 y1lında Hilmi Yavuz ile evliliği devam eden Nuran Yavuz, Acü (Ayşe) ise Nuran Hanım'ın ilk eşinden kızı Ayşe Ceren (Ülken)'dir. Bu durumda yazarın anlatıya müdahil olduğu ve gerçek dünyadaki kişileri ve bu kişilerin yaşamlarını kurmaca dünyanın içine dâhil ettiği görülür. Aynı zamanda burada yazar, bir roman yazmakta olduğunu belirterek üstkurmacanın roman yazan bir kişiyi anlatan kurmaca özelliğini de vurgulamış olur. Yazar bütün bu vurgularını yaparken "şimdi okumakta olduğunuz anlatının...", "size kendimi anlatayım..." gibi ifadeleri okuyucu ile bir sohbet çabası içinde olmayı gösterir. Böylece postmodern anlatının bir özelliği olarak okuyucu da metne dâhil edilir.

Düş, yaşamın uykuya yansıyan yüzüdür. Fehmi K.'nın gördüğü rüya onlardan biridir. Kurgu bile olsa anlatının hayata, gerçeğe dönük yüzüdür. Harf devrimi öncesinde var olan eğitim biçiminden korkan Fehmi K.'nın korkusunun yersiz olduğunu belirten yazar anlatıcı, eski eğitim sistemini eleştirir ve Atatürk'ün kurtarıc1lığını vurgular: "Fehmi K. 'nın birkaç gecedir üst üste gördüğü bir düşü, bu gece de görüp görmeyeceğini ögrenmekte acele ediyorum, çünkü. Bu düş neydi? Fehmi K., büyük bir odada ya da bir salondadır. Odada (salonda) çocuklar var, tümü de birer mindere oturmuş, önlerindeki rahlelere konulmuş olan Elifba üzerlerine eğilmiş, bir ă̆lzdan

Elif üstüne e, elif esri esre $i$, elif ötrü 0 ,

Be üstün be, be esre bi, be ötrü bö

diye bağırlyorlar. Fehmi K., korkuyor, çünkü okuyamıyor. Hoca ikide birde değneğine uzanıp Fehmi K. 'yı dövüyor...bu strada odaya (salona), sart saçlı bir adam giriyor, Fehmi K., onun yüzüne bakmaya çalışıyor; ama, o kadar aydınlık ki gözleri kamaşıyor -bakamıyor. Adamın elinde bir değnek var. Önündeki karatahtada bir harfi, eski harflere 'kaf' harfinin karşısına yeni harflerle yazılmış (k) harfini gösteriyor:

\section{Efendiler, İste buna $K$ (' $k a$ ') derler!}

diyor. Fehmi K., 'kaf, ka oldu demek', diye düşünüyor ve bu kez çocuklar bir ağızdan

Kaf Ka, Kaf Ka, Kaf Ka

diye bă̆ırmaya başlıyorlar.” (s. 149-150). Çocukların bir ağızdan Kaf Ka tekrarları, Franz Kafka'ya metinlerarası ilişki bakımından göndermeyi de içerir. Fehmi K.'nın gördüğü, gerçek ile düşün/kurgunun iç içe sunulduğu bu rüya, anlatının üstkurmaca boyutunun bir parçası olur.

\section{c) Kuyu}

Hilmi Yavuz, diğer anlatılarında olduğu gibi Киyu adlı anlatısında da zaman zaman gerçek yaşamından kesitlere yer verir. Bu durum, büyükbabasının ve büyükannesinin yaşadığı Güneydoğu ilinden ve orada konakta dayı ve amcalarının çocuklarıyla oynadığı oyunlardan bahsetmesi şeklinde yer alır. Babası Hikmet Bey ve babasının arkadaşı İzzettin Şadan Bey ve hasta annesi romanda kendine yer bulan gerçek hayattaki diğer kişilerdir. Anlatının kurmaca tarafiyla birlikte bu gerçekliklere de yer verildiği görülür.

\section{Okuyucunun Metne Yabancılaştırılması}

Yazar-anlatıcı, anlatıda yabancılaştırma etmenini kullanarak anlatının gerçek değil, bir kurmaca olduğu vurgusunu yapar. Böylece okuyucunun metin karşısında özgür ve özgün düşünebilmesi, sağlıklı bir eleştiri yapması amaçlanır. Üstkurmacanın bu kullanımı ile okuyucunun kendini anlatıya kaptırması önlenir ve okuyucuyu metinden/kurmaca dünyadan uzaklaştırılır. Anlatıcı, anlatının akışı içinde zaman 
zaman okuyucuya yönelerek okuyucunun, anlatının büyüsüne kapılmasını engellemeye çalışır. Bu durum anlatıcının, metin içinde soyut düzlemden somut düzleme/dış dünyaya ait varlıkları kullanmasıyla gerçekleşir. "Metnin okura yönelen anlatıcısl, çağdaş tiyatronun, oyunun ortasında birden izleyiciye yönelip onlarla konuşmaya başlayan anlatıcı-oyuncusu gibidir; içeriği yabancılaştırır, okurun konunun büyüsüne kapılmasını, duygusal bir ortama girmesini, edilginleşmesini önler" (Ecevit, 2008: 147). Üstkurmaca anlatıda diş dünyay1 olduğu gibi yansıtmaktan kaçınan yazar, onu yabancılaştırmak için tuhaf (garip) anlamını ifade eden grotesk tekniğini kullanır. Yabancılaştırma etmeni üstkurmacada önemli bir kurgu ögesi olarak karşımıza çıkar. "Yarattı̆g gerçeğin sanat düzleminde oynanan bir oyun olduğunu, kurmaca olduğunu vurgulamak isteyen çağımız romancısı, okurun dikkatini metnin biçim/kurgu özelliklerine yönlendirmek, onu etkinleştirmek ister; okurunun metinde anlatılanları gerçek olarak algılamaması ve kendini anlatılanların bir parçası olarak duyumsamaması için onu metne yabancılaştırır; bakışını duygusallıktan arındırır; okuru etkin kılar" (Ecevit, 2008: 130). Yazar anlatıcının okuyucu ile iletişime geçerek oyun oynama isteğiyle ilgili olan bu çaba sonucunda okuyucu kurguya yabancılaşır ve elindeki metnin kurmaca bir metin olduğu gerçeğini hatırlar. Böylece metin yapıbozuma uğratılmış olur.

\section{a) Taormina}

Postmodern anlatılarda dil ve dile bağlı oyunlar önemli yer tutar. "Postmodern yazar dil ile adeta oyun oynar ve daima bilinene, gelenekselleşmişe karşı oynayarak okuru metne yabanctlaştırır. Çünkü postmodern yazarlara göre sözcükler hiçbir zaman bireylere ait değildir; evrensel bir sistem olan dile aittir..." (Menteşe, 1996: 35). Postmodern biçimde kaleme alınan Taormina' da dil oyunları görülür. Felsefeci kimliğini anlatılarına yansıtan Hilmi Yavuz'un eserlerinde bu tavrı açıkça görülür.

Zaman dizimi, genel olarak zaman kavramı klasik roman için son derece önemlidir. Bu durum postmodern anlatılarda yerini üstkurmacaya bırakır (Ecevit, 2001: 72). Kimi kez oyun biçiminde, gerçeklerle çelişen kurgular, postmodern edebiyatın önemli özelliklerindendir. Taormina'da kurgusal olarak anlatılanları bu açıdan düşünmemiz mümkündür. Yavuz, özellikle hayalî kent olarak yazdığı Taormina'yı postmodern yapılanmaya uygun olarak oyun biçiminde kurgular.

Anlatı serisinin ilki olan Taormina çekirdek vakanın yanı sıra birbirleriyle bakışımlı kurgulardan oluşur. Ben anlatıcının diliyle anlatılanlar, bir bakıma başkahraman Yusuf Horoz'un otobiyografisidir. Şehir planlamasına ve felsefeye oldukça meraklı olan bu kişi, İstanbul'da yaşayan ancak bol bol Taormina'yı düşleyen küçük bir memurdur. Anlatının bir kısmı, Yusuf Horoz'un tatilini geçirdiği Bodrum'da geçer. Doğal olarak bu durum Hilmi Yavuz'un yazlarını geçirdiği Bodrum'u ve Yahşiyalı'sı beldesini akla getirir. Söyleşi ve yazılarında yeri geldikçe anlatılarından ve bazı motiflerinden söz ederken Taormina' daki mekânlara da değinir, yaşadığı gerçek mekânları kullandığını belirtir: "O dă̆ın ben 1984 yılında morardı̆̆ın gördüm. Taormina'da yazdığım gibi, fotoğrafta morardı̆̆ııı gördüm.” (Yavuz, 1999b: 77). Bu söylemlerden hareketle Hilmi Yavuz’un Taormina'y1 yaşamdan edindiği izlenimlerle kurar: "(Bodrum'da Rüzgârlı Camlar'ı keşfettiğimde, daha 'Taormina' yoktu; belki, gerek de yoktu 'Taormina'ya... Ali'nin, 1984 yılında, o camdan çektiği fotoğraf, dă̆ görüntüsü duruyor önümde, -ve dağ morarmış...)" (Yavuz, 1995: 78). Bodrum'da kaleme aldığ Geçmişs Yaz Defterleri'nde Taormina'yı kendine yazdırtan imgenin buradaki denizin ve Sartre'ın bir fotoğrafi olduğunu belirtir. Sartre'nin fotoğrafindan hareketle Taormina'yı yazmaya başlaması, "yazarın yazma tekniğini anlatan bir kurmaca" olarak ele alınmalıdır. "Şimdi akşamüstü. M. Motel'in bahçesinden denize, sonsuz denize baklyorum. Bir yelkenli, beyaz... Sartre'ın Simone de Beauvoir'la teknede çekilmiş bir fotoğrafi vardır. Arkada deniz ve uzakta yelkenliler görünür. İlk gördüğ̈̈mde sanki bu fotoğrafi daha önce yaşamış gibi duyumsadımdl. Bilinçdışımda neyi, hangi geçmiş ân'ı imleyendi bu - ok etmeli bir kök-imge! Bana Taormina'yı yazdırtan o imgedir işte.” (Yavuz, 1998: 115). Bütün bunlara karşın Taormina birçok yönüyle İstanbul'u da andırır. Bol bol hayaller kuran Yusuf Horoz'un memuriyet sıfatı ve ilgileri birlikte düşünüldüğünde, onun belediyede çalışan şehir planlamacılarından biri olduğu 
söylenebilir. Yavuz bu anlatıyı kaleme aldığı yıllarda İstanbul Belediyesinde Kültür İşleri Müdürlüğünü yürütmektedir.

\section{b) Fehmi K.'nın Acayip Serüvenleri}

Fehmi K.'nın Acayip Serüvenleri'nde ise anlatıcı olay akışını keserek okuyucuya metnin bir kurmaca olduğu mesajını verir. "Büyükbabam, babam, annem, İzzettin Şadan Bf. , Müstehase Hanım ise çoktan öldüler. Bu anlatıyı bitirirsem, gözlüklerimi çıkarıp komodinin üzerine koyduktan sonra ben de uyuyacağım." (s. 158). Böylece okumakta olduğunun birer kurmaca olduğunu vurgulama ihtiyac1 duyar.

\section{Yazarın/Anlatıcının Okuyucuya Seslendiği Bir Kurmaca Olması}

Yazarın/anlatıcının, kurmaca metin içinde okuyucusuna yönelmesi, doğrudan veya dolaylı olarak ona hitap ederek iletişime girmesi ve konuşması üstkurmacanın en belirgin özelliklerindendir. Çünkü postmodern anlatılarda okuyucu, önemli bir unsur olarak değerlendirilir. Aynı zamanda yazar/anlatıcı, okuyucuya seslenerek kurmaca ile geçeklik arasındaki ilişkiyi belirginleştirir; çünkü anlatıcı yazdıklarının gerçek olduğu iddiasında değildir, aksine her firsatta anlatısının bir kurmaca olduğu düşüncesini okuyucuda uyandırmak ister. $\mathrm{Bu}$ seslenmeler kurmaca dünya ile gerçek dünya arasında bir köprü işlevi görür.

Anlatıcının okuyucuya seslenmesi ve zaman zaman onunla sohbet etmesi, okuyucuyu aktif hâle getirir, onu zaman zaman anlatının hayalî dünyasından çekip alarak düşünmeye çağırır. Ancak istediği zaman dikkatini yine kurmaca dünyaya çevirme gücüne sahiptir. Üstkurmaca anlatıda okuyucunun varlığını kabul eden anlatıcının amacı, okuyucuyla iletişime girip okuyucunun dikkatini anlatı üzerinde yoğunlaştırmaktır. Okuyucu, okuma sürecinde pasif veya yüzeysel bir okuma yapmaması, romanı etkin ve bilinçli bir şekilde okuması konusunda uyarılır. Bu bakımdan postmodern anlatıda okuyucu, metin içinde yol gösteren imgesel ipuçlarını kaçırmayarak anlatıdaki ilişkiler ağını sebep sonuç ilişkisi içerisinde değerlendirebilecektir.

\section{a) Taormina}

Okura zamansal olarak dahi en son neye değinildiği hatırlatılır: “...demin yaşadiğım olguyu (bundan, normal bir okuma temposuyla tam 43 saniye önce okuduğunuz olguyu), klsaca, imgelemde yürürken bunun bir düş gibi gelmesi olgusunu açıklıyor. ” (s. 23).

Sorularla dikkati canlı tutulur: "Şimdi, Glyaseddin'in başkanlı̆̆ındaki bir delegasyonun "Taormina' ya gelişine ilişkin imgenin öyküsünü anlatmallyım size. Bu imgeyi ben gördüm -ve şimdi size anlatıyorum (yoksa daha önce anlatmış mıydım?)” (s. 25).

\section{b) Fehmi K.'nın Acayip Serüvenleri}

Fehmi K.’nın Acayip Serüvenleri adlı anlatıda zaman zaman okuyucuyla sohbet edilir:

“Ama durun sevgili okurlarım, her şeyin bir sırası var.” (s. 88).

"Böyle giderse Fehmi K. işyerine kolay kolay varamayacak, diye söylediğinizi duyuyor gibiyim, sevgili okurlar. Ama buna ikide bir de sizin yerli yersiz müdahalelerinizin neden olduğunu da, affinıza siğınarak, söylemek isterim. Ben Fehmi K. 'yi, elimden geldiğince elbette, şu lânet olasica sokaktan bir an önce kurtartp işyerine ulaştırmaya çabalarken, öykülemeyi zırt pırt keserek, ve iyi okur ukalalı̆̆ıyla, işimi güçleştirdiğinizin ayırdında değilseniz ben ne yapayım? Onun için sözü uzatmadan, (bu sözüm sanadır ey okur!) Fehmi K. 'nın işyerine dönelim. Çünkü, siz burada gereksiz gevezelikler ederken Fehmi K. işyerine varmış ve kravatını gevşetmiştir bile...” (s. 91)

"Bir gün, Roquentin'in Marquis de Rollebon'un yaşamını yazmaya başlaması gibi ben de İzettin Şadan Bey'in yaşamını yazacağım! Ama o güne kadar, siz sevgili okurlarım, bana ve Fehmi 
K.'ya katlanmak zorundasınız. Doğallıkla, Ne münasebet! sana niye tahammül edelim? Deyip, öykülemenin işte tastamam bu noktasında (belki de, daha buraya gelmeden!..) bu kitabı elinden firlatıp atacak okurların bulunduğunu adım gibi biliyorum. Sözüm onlara değil, işte, tastamam bu noktadan (.) sonra, anlatıyı okumayı sürdürme hoşgörüsünü gösterenlere'dir. Yazarların da 'iyi okur'un kimliği konusunda bir ölçüleri vardır; unutulmamalıdır..." (s. 93) Üstkurmaca anlatılarda yazar, okuyucuyu, metni dışardan, pencereden izleyen biri olarak değil; doğrudan olayın içinde aktif bir şekilde yer alan kişi olarak değerlendirmek ister. Bu anlatılarda yazar, okuyucuyu son derece önemsediğini belirtirken aynı zamanda kendi okuyucu kitlesinin, zeki ve dikkatli okuyuculardan olmasını gerektiğine dikkat çeker. Hilmi Yavuz bu tavrını şiirlerinde de sergiler, hedef kitlesi kültürlü okuyuculardır.

\section{c) Kuyu}

Kиyи'da da yazar anlatıcının sıklıkla okuyucuya seslendiği görülür. Genellikle bu seslenişlerde okuyucuların ön yargısı eleştirilir. Ünlem cümlelerinde kullanılan dil gittikçe ağırlaştırılır: "Ey Okur! Ey bigâne okur!" (s. 170), "Ey karayazıll okur! (s. 174), "Ey rahatına düşü̈n okur" (s. 176), "Ey kara bahtl okur!” (s. 179), "Bilisiz okur, nereden bileceksin?" (s. 179), "Ey lânetlenmiş okur!" (s. 181), "Ey kaaari, hadnâşinâs kaaari!" (s. 190), "Ey okur, ikiyüzlü okur!” (s. 195), "Ey okur, ey safdil okur!" (s. 212). Nitelikli okuyucu merkezli eleştiri kuramlarına ironi olarak değerlendirebilecek bu durum, metnin anlamlandırılmasında okuyucunun önemini vurgulayan postmodern anlayışın üstkurmaca anlayışını yansıtır.

Yazar, kendi benini ve adını gizlemeyerek anlatı boyunca okuyucuya önemli görevler düştüğünü ve okuyucunun dikkatli olması gerektiğini belirtir: "Hilmi Yavuz'un, öylesine pinekleyerek yazacağı anlatıyl, anlatının yazılacağı kuyuyu ve o kuyuyu açacak (kazacak) olan kuyucuyu, ki, mutlaka bir kuyucu olmallyd, evet o kuyисиуu bulmast gerekti. Ama neredeydi o kuyucu, onu anımsadl." (s. 190). Böylece üstkurmaca anlatılarda olan iç içe geçmiş olayları, yapılan kelime oyunlarını ve girift bir şekilde sunulan çoğul anlatıcıları ayırt edebilecek dikkatli ve zeki okuyuculara ihtiyacı olduğuna vurgu yapar. Alıntıda geçen "o kuyиcu” ifadesi ile "okuyucu” kastedilir; yazar, okuyucunun tıpkı bir kuyucu gibi anlatıda kazılar yapması, derinlemesine okumalar ve araştırmalar yapması gerektiğini belirtir.

Kuyu'da bir kahramanın bünyesinde üç ayrı kurgu birlikte anlatılır. Modernizmin gerçekliğine ve akılcı yaklaşımına karşı duruş, bir sorgulama olarak değerlendirilebilecek bu durum, zamansızlığı/zamanı öteleme anlamı da taşır. Anlatıda ağırlıklı aktarılan kurgu, çocuk Hilmi Yavuz'un yaşadıkları ve fantastik unsurlarla dolu dünyasıdır. Hilmi Yavuz anlatısını kaleme almak için kuyu gezerken kimi zaman çocukluk dünyasındaki bu unsurları anımsar. Yaşanılanların ağırlıklı zamanı, çocukluk anıları olmasına karşın bunların sonradan hatırlama biçiminde sunulması, okuyucunun bilincinde Kuyu'nun hangi zaman diliminde anlatıldığ 1 hususunda ikilem doğurur. Fantastik motiflerle donatılmış anlatıda zamanın ötelenmesi postmodern anlatıya uygun düşer. Gerçeklik gibi sunulanların aslında ölüm ve kuyu bağıntısı üzerine yazılmış kurgu/kurgular olduğunu belirten yazar, okuyucuyu bilinçli bir tavırla çelişkide bırakır: "Ey okur! Ey karayazılı okur! Kuyu ve ölüm bağıntısı üzerine Hilmi Yavuz'un ne yazacă̆ın bilebilmeniz mümkün değil, ama ben ne söyleyeceğimi biliyorum. Ölüm ve kuyu bağıntısl, Hilmi Yavuz'un oturduğu apartmanın hemen karşısındaki devasa otel inşaatı dolayımında somutlaniyor." (s. 174-175). Hilmi Yavuz otel inşaatından hareketle aslında kenti, tüm varlıkları ve yaşanmışlıkları içine alan büyük bir kuyuya benzetir. Kuyu kent, kent de kuyu olur. Böylelikle kentle kuyu birbirleriyle özdeşleşirler.

\section{Roman Okuyan/Yazan Bir İnsanı Anlatan Bir Kurmaca Olması}

Anlatıda "roman, hikâye, kitap, okumak, yazmak ve okuyucular" gibi sözcüklerin yer alması, anlatının/metnin bir kurmaca olduğu, roman okuyan/yazan bir insanı anlatan bir kurmaca olduğunun göstergesidir. 
a) Taormina

Taormina'da roman okuyan/yazan iki kişinin varlığından bahsedilir ve Yusuf Horoz'un roman okuyan/yazan bir kişi olarak okuyucunun karşısına çıktığı görülür:

'Ben bir felsefekurgu yazmak istiyordum; 'bilimkurgu' (science fiction) olur da felsefekurgu neden olmasın? Ben öteden beri, Felsefenin bir kurgu olduğunu savunmuşumdur, kurmaca olduğunu!" (s. 31)

Felsefeci olamayacağını anlayan Yusuf Horoz, romancılığa karar verir. Böylece postmodernizmin uzantıs1 olarak kurgu içinde kurguya geçilerek kahramanımız bir roman yazma denemesine girişir:

"Felsefe geleneğinin olmadı̆̆ bir ülkede yaşadığıma göre, felsefeci olabilmek için, felsefe geleneği olan bir kent imgesini kurgulamak durumundaydım. Buysa beni, çok açık bir antinomiye götürüyordu: Felsefe geleneği olmayan bir kentin insant, felsefe geleneği (hangi gelenek? O da ayrt konu!) olan bir kent imgesinin içinde nasıl var olacaktı? Bu antinomiyi çözmeden önce, şunu düşündüm: En iyisi, felsefeci olmayı bir yana burakmak, -ve roman yazmayı denemekti! ... Böyle dedim, -ve bir gün, nescafeme süt koymayı unutarak, romanıma başladım:" (44-45). Yusuf Horoz' un yedi sayfa süren bu iç roman denemesinde Hilmi Yavuz'un yaşamından izler bulunur; ancak otobiyografik roman yazmak için yola çıkan Yusuf Horoz, yazdıklarının otobiyografi olmadığını anlayınca romanını sürdürmekten vazgeçer.

Taormina, roman yazan kişiyi anlatan kurmaca olduğunu sik s1k gün yüzüne çıkarır. "Benim yine Taormina'ya o büyülü söz'e, o imgeye dönmem gerekiyor. Çünkü ancak orada yazdıklarım ve düşündüklerimle, var oluşum bir anlam kazanıyor. 'Taormina' dışında yazdıklarımın tam bir bayağılık ve sıradanlık taşıdığını biliyorum artık. Bu yalıtkanlıktan kurtulmak için Taormina'ya sığınıyorum yine." (s. 52-53)

"Kimdim ben ve neden bunlarl yazıyordum?" (s. 37)

Anlatıda yazarın zaman zaman kendi romancılığını eleştirdiği de görülür:

"Hay Allah müstehakkını versin Yusuf Horoz! diye ilendim kendi kendime, böyle saçmasapan şeyleri yazarak romancı olmayı düşündügüm için, kendime fena halde içerledim. Günün birinde bu yazdıklarımı yayımlarsam, romanla ilgili bölümünü çıkarmalıyım, dedim. Öyle de yaptım, şimdi sizin okuduğunuz, elinizde tuttuğunuz kitapta bu bölümün olmaması bundan dolayıdır. Siz, sadece benim bir roman denemesine giriştiğimi, bu denemenin (benim açımdan) bir fiyasko olduğunu bilecek, ama ne yazdı̆̆ımı asla öğrenemeyeceksiniz!” (s. 52)

Taormina aslında bir imgedir. Yazar, bu imgeye mekânsal bir anlam yükler. Burayı gerçek hayatın her türlü sıradanlığından kaçarak kurtulduğu, eleştirel bakımdan huzura erdiği bir sığınak olarak tanımlar. Ayrıca Taormina, sonsuzluğu, çocukluğunun saflığını ve masumiyetini simgelemesi itibariyle deniz ve beyazlık (s. 53) imgeleriyle de ilişkilendirilir.

Taormina, roman yazan bir kişiyi anlatan kurmaca olduğu gibi aynı zamanda roman okuyan bir kişiyi anlatan kurmaca olarak da dikkat çeker. Örneğin sahaf dostu Alaeddin'in dükkânında rastladığ1 Acaib 'ül Letaif yani Hitay Sefaretnamesi adlı eseri okumaya koyulur:

"Alaeddin'den izin isteyerek oractktaki sandalyelerden birine oturdum ve Nevâdir-i Eslâf külliyatının altıncısı olan Acaib'ül Letaif'i, yani Hıtay Sefaretnamesi'ni okumaya başladım.” (s. 54). Böylece Taormina'da okunan delegasyon heyeti hakkında verilen bilginin aslında Hitay Sefaretnamesi'ndeki pek çok olayla benzerlik taşıdığg görülür.

Yusuf Horoz'un, Hoca Giyaseddin Nakkaş'1n Acaib'ül Letaif adlı sefaretnamesini okuduğu ve okuduklarından esinlenerek Taormina adlı anlatıyı yazdığı belirtilir. "Prensin huzurundan ayrılmadan 
önce de, delegasyon üyelerinden her birine birer şahin (metinde 'sungur' diye geçiyor) armağan etmiş ve zencefil çayı sunmuş" (s. 25-26), "bu beyaz, gizemli filciklerin bana Çin'i, Maçin'i (metinde 'Hıtay' diye geçiyor H.Y.)" (s. 72) cümleleriyle de örneklenir.

Yusuf Horoz'un felsefe ve hayat anlayışı, bu kurgunun belirleyicisi olur: "Buraya kadar anlattıklarımın hiçbir anlamı olmadiğını biliyorum. Aslında, 'Taormina' bahane, belki! Ben bir felsefekurgu yazmak istiyordum; 'bilimkurgu' (science fiction) olur da felsefekurgu niye olmasin? Ben öteden beri, Felsefenin bir kurgu olduğunu savunmuşumdur, kurmaca olduğunu!” (s. 31). Aynı şekilde Yusuf Horoz'un roman yazan bir kişi olduğu kendi kalemiyle dile getirilir.

Kurmaca içinde kurmacayı barındırması bakımından zengin olan Taormina'da Yusuf Horoz'un roman okuyan/yazan bir kişi olarak okuyucunun karşısına çıkmasının dışında 1422'de Hoca Gıyaseddin El Nakkaş'ın yazdığı ve Şeyhülislam-ı esbak Küçükçelebizâde İsmail Asım Efendi'nin tercüme ettiği eserin yazımından da bahsedilir. Timur'un oğlu Mirza Şahruh'un Çin imparatoruna gönderdiği elçiler delegasyonunda bulunan Hoca Giyaseddin, 1419'da Herat'tan yola çıkarak yaptığı uzun ve zorlu bir seyahat esnasında tuttuğu notları Herat'a döndükten sonra toplar ve böylece ortaya Acaib'ül Letaif, diğer adıyla Hıtay Sefaretnamesi çıkar. (s. 54-62)

Taormina adlı anlatının, roman okuyan bir kişiyi anlattığı kurmaca olmasının yanı sıra zaman zaman anlatıcının okuduğu bir metni okuyuculara aktardığı kurmaca olarak sunulduğu görülür: "Buraya gelince durdum, okuduklarımın bana belli belirsiz bir şeyler anımsattığını düşündüm. Sanki bir déja lu söz konusuydu burada; sanki burada okuduklarımı daha önceleri bir yerlerde okumuş gibiyim." (s. 60). Anlatıcı Hoca Gıyaseddin Nakkaş'ın “Acaib'ül Letaif” adlı eserini okumakta olduğunu belirtir ve Hitay İmparatorluğuna giden elçiler hakkında bilgiler sunar. Bütün bunlardan hareketle aslında Hilmi Yavuz'un Taormina adlı anlatısını yazarken "Acaib' ̈ul Letaif” seyahatnamesinden sıklıkla yararlandığı ve bu seyahatnamedeki pek çok unsurdan yola çıkarak kurmaca yazarı Yusuf Horoz'a benzer deneyimler yaşattırdığı dikkatlerden kaçmamıştır.

\section{b) Fehmi K.'nın Acayip Serüvenleri}

Postmodern anlatılarda sıkça görülen anlatıcı ve yazarın tam olarak ayırt edilememesi bu anlatıda da görülür. Fehmi K.'nın Acayip Serüvenleri'nde anlatıcı kişinin, aslında yazarın kaleme aldıklarını okuyarak okuyuculara sunan konumunda olduğu belirtilir:

“... Fehmi Kavkı da yataktan ister istemez çıkmak durumunda kaliyordu ve biz, bu anlatının okurları, böylece, onun mavi çizgili bir pijaması olduğunu olanca açıkliğıyla ve hiçbir kuşkuya yer olmadan, ögrenmiş bulunuyorduk." (s. 86). Anlatının başında olan "okurlar" ifadesi daha sonraki süreçte anlatıcının dilinden "biz okurlar" şeklini alması aslında anlatıcının, aynı zamanda kitap okuyan birisi olduğunun göstergesidir.

“... Fehmi Kavkı’nın ayaklarının üşüdüğünü de bu vesileyle ögrenmiş olacak olan biz okurlar için, bu anlatının yazarının, yani benim, söyleyeceğim bir çift söz olmalıdır elbette. ” (s. 86). Burada da anlatıcının aynı zamanda anlatının hem yazar-anlatıcısı hem de okuyucusu olarak okuyucunun karşısına çıktığı görülür.

“... anlatı yazarı olarak oldukça tutucu bir kimliğim olduğunun da altını çizmek istiyorum. Bu, şu demektir: Ben kahramanlarımı yadırgatıcı, kışkırtıcı olmayan tiplerden ya da karakterlerden seçerim. Onun için de Fehmi Kavki'nın (bundan sonra, Fehmi K. diye antlacak) bir banka memuru olmasindan daha doğal bir şey yoktur...

Buraya kadar anlatılanlar, bir bankada çalışmakta olan Fehmi K., bir yaz sabahı evinden çıkıp işyerine doğru gidiyordu, diye özetlenebilir. Evet özetlenebilir özetlenmesine de, ben öyle ince, pestil inceliğinde klytırlk romanlar yazıp üzerine 'anlatt' diyerek okula yutturmaya çalışan yazarlardan değilim." (s. 89) 
“... bu anlatının yazarı olarak, Fehmi Kavkl'nın yalnızlı̆̆ına izin vermeyeceğimi sizlere, siz okurlara açık açık söylemekten gurur duyuyorum.” (s. 88).

Anlatıda asıl anlatı yazarının dışında roman kahramanlarından Selim Taşı1'ın da roman okuyan ve okuduklarından hareketle roman yazan bir kişi olduğu görülür:

"Bir gün, üvey babasının kitaplı̆̆ında (Müstehase Hanımın dördüncü kocasıdır bu) bir yazarı keşfetti. Yazarın adl, Jean-Paul Sartre idi. Kitapllkta bulduğu romanın adı da La Nausée (ben olsam bu kitaba Melankoli adını verirdim) Fransızca bildiği için La Nausée’yi alıp okumaya koyuldu Selim Taşıl... şöyle düşündü: 'Raquentin' in önünde, onu bu yaşamöyküsünü yazamamasını bağışlatacak, ya da -en azından- hafifletecek nedenler var. Ama benim yok! Öyleyse, Roquentin'in yapamadiğını, ben neden yapamayayım!' Böyle dedi ve Marquis de Rollebon'un yaşamöyküsünü yazmaya oturdu. Kuşkusuz, Roquentin'in bulgularından da yararlaniyordu, ama o, biraz da kendi kafasina göre bir Rollebon yazmak istemekteydi. Bu, doğallıkla onun, Sartre'nin kullandı̆̆ anlamda bir 'Kendi-kendini aldatma' içine düşmesine engel olmadl. Hakikati, Öteki'nden değil (o zaman yalancı olurdu), ama kendinden gizleyerek yazmaya, yazmaya, yazmaya koyuldu." (s. 101-102). Anlatının diş halkasında yer alan Hilmi Yavuz, anlatıyı kaleme alan kişi olurken anlatı içerisinde bir karakter olan Selim Taşıl'ın da roman yazan bir kişi olarak okuyucunun karşısına çıkar. Selim Taşıl, hem Roquentin'in romanını okumakta hem de okuduklarından yola çıkarak romanı kendisi tekrar kaleme almaktadır.

Fehmi K.'nın Acayip Serüvenleri'nde anlatıcı ve kurgunun bir arada oluşu İspanyol ressam Diego Velasquez'in (1599-1660) Las Meninas adlı resmini andırır. Sanat tarihinde önemli bir yere sahip olan bu ünlü resimde ilkin elinde firçasıyla resim yapmakta olan Velasquez görülür. Resmin arka planında yer alan aynanın içinde ise kralla kraliçe görülür. Böylece resme bakan biri, elinde paleti ve firçasıyla tuvalin önünde durmuş, kralla kraliçenin resmini yapmakta olan Velasquez'in atölyesine girmiş hissine kapılır. Resmin ön planında ise bir ışık içinde, küçük prenses Margarita durur. Kurgu ve anlatıcı açısından Fehmi K. 'nın Acayip Serüvenleri'nde durum bundan pek farklı değildir. Okuyucu, anlatıcı yazar veya yazar anlatıcı olarak değişik adlarla ortaya çıkan anlatıcının anlatısını okunur. Her iki kurmaca dünyada da kahramanlar, Hilmi Yavuz'dan izler taşır. Bu açıdan anlatı, üstkurmaca düzlemde gerçekleşen ve eserin yazılış süreci hakkında bilgi veren bir anlat1/kurgu olarak okuyucu karşısına çıkar.

Fehmi K. 'nın Acayip Serüvenleri, üstkurmaca bağlamında, anlatının kurgu yapılması ile birlikte bir o kadar da Hilmi Yavuz'un kendi yaşam anlatısıdır. "Şimdi, yazın kuramını, ikide bir gündeme getirmeyi bir yana bırakarak, yani, yazın kuramı'nı bir yana bırakarak, yaşamöyküme dönelim, Cesare Pavese, Günleri değil, ânları anımsarız, diyor -ne kadar doğru!.. Ben de çocukluğundan belleğimde kalan an'ların anı'ya dönüşsenlerini (dilsel açıdan an'a bir ' ' harfinin artiküle edilmesiyle gerçekleşen bir dönüşümdür bu) anlattya dönüştürme gibi bir iş edindim kendime. Kendi anlatımı anlatacağım. Kendimi ya da anlattyı. Dolaylsiyla, Bu anlat neyi anlatır? sorusuna, Bu anlatt, anlattyı, yani, ben'i anlatır, diye yanıt vereceğim." (s. 141). Bu çerçeve kurguda, anlatıyı yazdıktan sonra uyumaya geçen yazarın söylemi aynıdır: "Büyükbabam, babam, annem, İzzettin Şadan Bf., Müstehase Hanım ise çoktan öldüler. Bu anlatıy bitirirsem, gözlüklerimi çıkarıp komodinin üzerine koyduktan sonra ben de uyuyacağım." (s. 158).

Fehmi K. 'nın Acayip Serüvenleri gerçek ile kurmacanın iç içe olduğu bir anlatıdır. Selim Taşıl, her iki kurgusal dünyanın, tali olmasına rağmen ortak kahramanıdır. Anlatıcının, otobiyografisinden aktardıklarıyla anlatının gerçeklik yönü imlenir ve bunlar, çerçeve kurgunun bir parçasını oluşturur. Anlatıya adı verilen Fehmi K.'nın ilgi duyduğu iş arkadaşı Anette ve kendisi, gerçek olmayan kurmaca karakterdir: "Fehmi Kavkı erkenden uyandı ve dosdoğru aynaya baktı. Aynada gördü̈̆̈̈ kendisiydi; ve -bir gece önce hamamböceğine dönüşmemiş olduğu için Tanrı'ya şükretti. Öyle ya, Fehmi Kavkı bir anlatı kahramanıydı (bu anlatının kahramanı) ve anlatı kahramanlarının sık sık değilse bile, arada bir, hamamböceklerine dönüştükleri biliniyordu. Çoğu kez, okurların bile bildiği gerçekliktir bu... " (s. 
85). Anlatıcı burada bir anlatı kaleme aldığını belirtir, böylece üstkurmacanın bir roman yazan kişiyi anlatan kurmaca özelliği görülmüş olur.

Üstkurmaca anlatının önemli bir özelliği de roman yazan/okuyan bir insanı anlatan kurmaca olmasıdır. “...burakalım Fehmi K. 'yl, Selim Taşıl'l, valdesi Müstehase Hanımı... Anette'i ve İzzeddin Şadan Beyi, ben size kendimi anlatayım... Benim şu anda yazmakta olduklarım..." (s. 113) ifadeleri ile yazarın anlatıya doğrudan müdahale ettiği ve artık kendisini anlatan bir anlatı yazmaya karar verdiği görülür. Bu durum Hilmi Yavuz'un kurmaca dünyadan çıkıp gerçek dünyaya gitme isteğini belirtir. Dolayısıyla yazar olarak kurmaca bir eser yazdığının ve anlatıdaki tüm karakterlerin bütünüyle kendi hâkimiyetinde ve tasavvurunda olduğunun kanıtıdır. Anlatıdaki en güçlü kişi yazardır, gerçek olan Hilmi Yavuz'dur, diğer karakterler onunla hayat bulmuş hayali simgelerdir. Anlatıcı, roman yazdığını şu ifadeleri ile açıkça dile getirir: "Fehmi K., bir küçük banka memuru olarak tasarlandı ve şimdilik kendisi bu tasarıma bağll kalmayl sürdürüyor. Size söyledimdi, ama Fehmi K., 16 Haziran günü doğmuştur. Bu, опи 16 Haziran günü tasarladım demektir.” (s. 111).

\section{c) Kuyu}

Anlatıda Hilmi Yavuz, anlatı yazmaya hazırlanan bir kişi olarak yer alır. Anlatının asıl yazarı olarak kendisinin aynı zamanda anlatının bir karakteri olarak da okuyucunun karşısına çıktığı görülür. Ölüm ile kuyu arasında ilgi kurar ve işe öncelikle anlatısını yazabileceği uygun bir kuyu aramakla başlar: "Hilmi Yavuz, bu son anlatısinı (şimdi yazmakta olduğu anlattyı) yazmaya başlamadan önce onu nerede yazacă̆ını düşündü. Ne yazacağını biliyordu kuşkusuz; ama nerede yazabileceğini bilmiyordu ..." (s. 165). "Hilmi Yavuz'un anlatısını yazmak için kuyuyu seçmesi, anlatının 'ölüm'le ilgili olmasındandı. Hilmi Yavuz, ölümle kuyu arasında bir bağlantı olduğunu ölüm ’ün (kuşkusuz kendi ölümü olacaktı bu!) ancak bir kuyuda yazılabileceğini düşünüyordu!’ (s. 171). Anlatının ölümle ilgili olması ve ölümün deneyimlenmek istenmesinden ötürü bir kuyu tercih edilir. Böylece kuyu aracılığıyla bilinçdışına ait derinliklerin ortaya çıkması hedeflenir. İnsan kendi ölümünü sonradan yazamayacağı ve bir başka ifade ile kendi ölümüne seyirci kalıp tanık olamayacağına göre kendi ölümünü de yazamaz, görüşünde olan Freud'un görüşü aşılmaya çalışılır.

Anlatı mekânı olarak "kuyu" yazara kendi ölümünü deneyimleme firsatı sunmakla kalmaz anlatının yazılma süreci hakkında okuyucuda bir kanaat oluşmasını sağlar: "Anlatının bundan sonrasının, Hilmi Yavuz'un aradı̆̆ kuyuyu gerçekten bulmuş mu, yoksa bulmuş değil de ona sanki bulmuş gibi mi gelmiş olduğu olasılıklarından hangisinde temellendirileceğini kestirmek hiç de kolay olmasa gerek. Hangi olasılık söz konusu olursa olsun, önemli olan, yazarın ölüm/kuyu bağıntısın gözden kaçırmamasıdır. Kuyu da, ölüm de karanlıktır, çünkü...” (s. 195). Kendi ölümünü hissedebilip yazabileceği bir kuyu arayışına giden yazarın, daha sonraki süreçte anlatısını yazmak için nasıl bir yol izlediği belirtilir. "Ölüm”ü "kuyu” ile imgelemesi son derece önemlidir, çünkü ikisi de karanlık, 1ssız ve soğuktur. Yazar, anlatısında kentin büyük, yorgun, tozlu ve külrengi olduğunu tasvir ederken anlatının "ölüm” teması üzerine kurulduğunu ve dış dünyanın böyle bir ruh hâli içinde değerlendirildiği mesajını verir.

\section{Kurmaca İçinde Kurmaca Anlatılması}

Kurmaca içinde kurmaca "Yapı kavramı, anlatıcının iç içe geçmesiyle her bireysel kutu gerçekliğine karşı koyan Çin kutusu yapısını içermektedir" (Waugh, 1996: 30). Kurmaca düzleminin iç içe geçmiş sarmal yapısı, aynadaki görüntüler gibi romanın içine serpiştirilmiş hikâyelerin iç içe anlatılması ile sağlanır. Aynı şekilde anlatılan bu hikâyeler çokkatmanlı bir yapı oluşturarak üstkurmaca düzlemlerinin sarmal yapısını oluşturur.

\section{a) Taormina}

Hilmi Yavuz, Üç Anlatı' da kurmaca içinde kurmaca yazdığını açık bir şekilde ifade eder: "Sanki on ayrı romana aynı zamanda başlamış da her birinin başlangıç bölümleri, tıpkı Rusların geleneksel, 
tahtadan yontulmuş biblo bebekleri gibi içi içe konulmuş ya da yazılmışsa benzer bir klş gecesi yolcusunun yol düşünceleri! Böylesi, diyeceğim, salt başlangıçlardan oluşan on roman taslağının birbirinin içine geçmesi (metinde 'emboités' diye geçiyor) nasil hem okuru hem de okuma eylemini aynı zamanda gündeme getiriyorsa, kış geceleri yolculukları da yolcuyla yolculuk duygularını (ya da eylemlerini) aynı zamanda gündeme getirir. Ne kadar çok yolculuk duygusu vardır! Gerçekte, belki bir yolculuk da değildir bu;- ya da bir roman değildir. Yolculuğun yolculuğu, ya da romanın romanidır. Şöyle de düşünebiliriz: Öyle bir roman yazılmalı ki, bu romanın başkişisi o romanın okuru olsun! ... Aynayla bellek arasındaki ayrımın belirsizleştiği bir bölgede, 'yazılmış olan roman 'la, 'yazılmakta olan roman' in birbiriyle örtüştüğü bir yazma eylemi olsun!’' (s. 62-63)

Üstkurmaca tekniğinde görülen kurmaca içindeki kurmaca anlatım ayrıntılı bir şekilde sunulurken aynı zamanda yazarın yazma tekniği hakkında bilgi de verilir. Artık yazının ve yazma eyleminin kendisi yazıya konu edinir ve bütün bunlarla beraber okuyucu, anlatıyı dışardan izleyen değil; anlatının doğrudan içinde olan, hatta zaman zaman yazarla iletişim içinde olandır. Üstkurmaca anlatılarda mevcut eserden hareketle bir başka eserin tekrar tekrar yazıldığı vurgusu yapılır; çünkü asıl olan konu değil mevcut konunun nasıl anlatıldığıdır. Bu bağlamda yazar Dostoyevski, Franz Kafka, İtalo Calvino, Milan Kundera, Elias Canetti, Hermann Broch, Rilke, Eliot, Freud gibi pek çok sanatçıyı okuduğunu belirtir. (s. 65)

Yazar Taormina adlı anlatıyı üstkurmaca ile yazdığını ifade eder. Üstkurmaca anlatılarda olayların iç içe geçmesi, anlatıda ayna imgesiyle ortaya konulur: “...imgenin bir yanı, öteki yanının aynadaki görüntüsüymüş gibi, bu kıyldakilerin eylemlerinin, tastamam öteki kıyldakilerin eylemlerine uyması anlamına geliyordu. Imge ("Taormina") aynayla çoğaltılmış gibiydi..." (s. 11). Taormina'nın aynasal bir bakışımının olması, kurmaca içinde kurmaca olduğunun göstergesidir. “...olguların zamansal olarak düzenleniş biçimi ('öncelik', 'sonralık', 'eşzamanlılık'), o olguları temsil eden nesnelerin (kutular) uzamsal olarak düzenleniş biçiminden çok daha sınırlıdır. Oysa 'Taormina'da durum böyle değildi. Yani, olguların ve nesnelerin zamansal ve uzamsal düzenleniş biçimleri arasındaki birebir bir tekabül ilişkisi vardl. "Taormina'da bir kutuyu ötekinin üzerine koyabilirdiniz..." (s. 17). Yazar Üstkurmaca bir anlatım tercih ettiğini ve bu anlatımda olayların girift bir şekilde sunulduğu bilgisini verir. Taormina'da olaylar, nesneler ve uzamlar eşzamanlı olarak birbirinin yerini tutabilecek ve birbirini karşılayabilecek şekilde konumlandırılır.

Taormina'da ana olay halkasının dışında birçok olay halkası görülür. Kurmaca içinde olan ve ana olaydan ayrı anlatıya giren bu kurgular, postmodernizmin önemli özelliklerinden üstkurmaca düzleminde gerçekleşir. "Edebiyatın konusu, ne gerçekçilerin 'dış dünyası', ne de romantikler ve modernistlerin 'iç dünya'larıdır artık. Edebiyat/metin, kendini anlatmaktadır postmodernist edebiyatta. Gerçeğin belirsizleştiği, klişe kalıplarla üretilip tüketime sunulduğu bir çağın sanatçısı, kendisine de yabancl gelen bu ortamda, gerçeği yeniden üretmek yerine rotayı farklı bir estetik doğrultuya kaydırmıştır; salt sanatsal yaratıcılığ , hem biçim hem de içerik/motif dü̈leminde odağa almış, onunla oynamaktadır. Bu ayn zamanda, edebiyat estetiğini tersyüz eden bir adımdir; yeni bir metinsel ontolojinin oluşması demektir." (Ecevit, 2001: 184).

“...yükselmek ya da yukarı çıkmak, 'Taormina'lllara göre, bir yanılsamadan öte bir şey değildi... ve gerçeklik bizi yanıltıyordu... Evren onlar için eşdüzlemde kurulmuştu” (s. 12-13). Üstkurgusal olan bu anlatıda Taormina, aslında mekân içerisindeki bir başka mekânı imgeleştirir. Anlatıda yazar, Taormina'yı "düşlerimin büyülü aynası" (s. 15) olarak tanımlar. Bu nedenle Taormina aslında uzamsal bakımdan kurmaca içindeki kurmaca mekâna işaret eder.

Birinci kurgusal düzlemde Hilmi Yavuz'un Taormina adlı anlatısı yer alır. İkinci kurgusal düzlemde ise Yusuf Horoz adlı bir devlet memurunun yaşantısı anlatılır. Yusuf Horoz, arkadaşı Erkut'la Viyana'da dolaşırken vitrindeki sıralanmış on adet fil heykelciğini seyreder (s. 71), İstanbul Fatih'te seyyar gazeteci olan Gıyaseddin Ağabey'in tezgâhı önünde Kıztaşı'nı seyretmesi ve onu beyaz bir 
yelkenliye benzetir. Bir sonraki kurgusal düzlemde ise Yusuf Horoz'un gerçek dünyada gördüklerinden hareketle hayali bir kent olarak yazmış olduğu Taormina adlı kurmacaya yer verilir. Dördüncü adımda Gıyaseddin'in başkanlığında delegasyon heyetinin Taormina'ya gelmesi anlatılır.

Taormina'ya gelen delegasyon heyetinin başında Gıyaseddin adlı biri vardır. Bu heyetin Taormina'ya gelirken tam üç yıl süren yolculuğu anlatır. Gıyaseddin başkanlığındaki heyet Taormina prensini ziyarete eder: "Taormina'ya geldiklerinde (hangisi?) atlarından inmişler ve saray kapısına giden yolda sağll sollu yerleştirilmiş beşer beyaz filin arasindan geçmişler. (Taormina'da tastamam on bir beyaz filin olduğu biliniyor). Prens, onlarl salonda kabul etmiş ve 'Taormina' cezaevinde tutuklu 700 azılı suçluyu (büyük bir bölümü siyasal suçlu) o akşam, Glyaseddin delegasyonu onuruna verilen şölene çağırdığını bildirmiş. Prensin huzurundan ayrılmadan önce de, delegasyon üyelerinden her birine birer şahin (metinde 'sungur' diye geçiyor) armağan etmiş ve zencefil çayı sunmuş. Ayrica, konukların güzel eşleri için de top top ipler armağan etmiş. Onlar da 'Taormina' prensine, ülkelerinden getirdikleri göz alıcı güzellikteki atları sunmuşlar. Prens bu atlardan biriyle ertesi gün ava çıkmış vetalihsizlik bu ya!- attan düşerek yaralanmış. Prens çok kızmış buna ve Glyaseddin delegasyonunun tutuklanmasını buyurmuş. Ben bu imgeyi gördügümde akşam oluyordu ve kuşkusuz, yelkenlilerin beyazlı̆̆ından o kertede kesinlikle söz edemiyordum artık." (s. 25-26).

Yusuf Horoz'un delegasyon heyetinin Taormina'ya gelişini anlattığı bu bölüm ve bu bölümde geçen kişilerin isim benzerliği, sayısı, olayların gerçekleşme zamanı ve yapılan çağrışımlar gibi pek çok unsur aslında Hoca Gıyaseddin Nakkaş'ın Acaib'ül Letaif adlı sefaretnamesinde geçen olayların bir benzeridir.

Beşinci düzlemde Taormina'da Yusuf Horoz'un, sahaf dostu Hoca Alaeddin'in dükkânında rastladığı Acaib'ül Letaif adlı sefaretnameyi okuması ve sefaretnamedeki olayların anlatıldı̆̆ kurmaca bulunur. Yusuf Horoz, sahaf dostu Alaeddin'in dükkânında rastladığı Acaib'ül Letaif yani Hıtay Sefaretnamesi adlı eseri okumaya koyulur ve burada okuduğu olaylardan esinlenerek kendi yazdığ Taormina adlı anlatısını kurgular (Yazar bu eserin orijinalini okumadığını ancak Fuad Köprülü’nün "Milli Tetebbular Mecmuası"ndan bilgi edindiğini belirtir (s. 55). Böylece Taormina'da okunan delegasyon heyeti hakkında verilen bilginin aslında Hıtay Sefaretnamesi'ndeki pek çok olayla benzerlik taşıdığ 1 görülür. Hatta Taormina'ya Gıyaseddin başkanlığında gelen delegasyon üyelerine prens tarafından verilen "şahin"den bahsedilirken parantez içerisinde "metinde sungur diye geçiyor" ibaresi aslında Yusuf Horoz'un bu anlatıyı Acaib'ül Letaif yani Hitay Sefaretnamesi adlı eserden esinlenerek yazdığının bir kanıtıdır.

Son olarak Ali Emiri Efendi'nin, Mirza Şahruh Sultan'ın elçisi olan Hoca Gıyaseddin Nakkaş'ın Herat'tan yola çıkarak Hitay'a yaptığı yolculuğu ve geri dönüşünü anlatılır. Timur'un oğlu Mirza Şahruh'un Hitay (Çin) imparatorluğuna gönderdiği elçilerden biri olan Hoca Gıyaseddin Nakkaş, hükûmet merkezi olan Herat'tan Hitay'a zorlu bir yolculuk yapar. Yanında yüz elli (150) kişiyle yolculuk yapan Hoca Gıyaseddin Nakkaş, kötü hava şartlarında üç yıl süren bu zorlu yolculuğu ve yolculuk sırasında gördüğü doğal ve tarihî güzellikleri not eder. Gezip gördüğü yerleşim yerlerinin insanları ve bu insanların gelenek, görenek ve yaşam şekilleri hakkında detaylı bilgiler sunar ve ilginç hikâyeler aktarır. Hıtaylıların yurtlarını nasıl inşa ettiklerini, hangi geometrik şekillerle yeni ve ilginç bir yerleşim planı kurduklarını anlatır.

\section{b) Fehmi K.'nın Acayip Serüvenleri}

Fehmi K. 'nın Acayip Serüvenleri'nde iki anlatı kurgusu görülür: İlkinde kurgu, Fehmi K.'nın evinde başlayıp çalıştı̆̆ bankadaki odasında sürer ve ardından kendi evinde sonlanır. İkincisinde ise kahramana dönüşen anlatıcılardan birinin gözlem ve duyumları anlatılır. Kahramanları ise başta Fehmi Kavkı (anlatıda soyadı sadece K. biçimindedir), Anette ve Selim Taşıl'dır. Yaşanılanlar bir gün içinde tamamlanır. Küçük bir banka memuru olan Fehmi Kavkı yalnız yaşayan biridir. İşyerinden arkadaşı Anette, Türk vatandaşı olmuş Yahudi bir kızdır. 
Fehmi K.'nın Anette'den her gün aldığı tek sigarayı yakmaksızın kullanması, entelektüel ilgisi, saçlarını arkadan öne doğru taraması ve her şeyden önemlisi şiir yazması Hilmi Yavuz'u anımsatır. Anlatının problem edildiği bu kurguda yaşama dair kayda değer bir hadisenin gerçekleşmediği görülür. Daha sonra anlatıya dâhil edilen kurgunun yeni kahramanı Selim Taşı'’n kim olduğu ve yaşamı hakkında bilgi verilir. Böylece ikinci kurgunun oluşumu için gerekli zemin hazırlanmış olur. Selim Taşıl, bu anlatının tali kahramanıdır.

Her iki kurguda aktarıcı kendini çeşitli adlarla tanıtsa bile aynı kişi, her şeyi bilen yazar anlatıcıdır. Çerçeve kurgu olarak adlandırdığımız ikinci kurguda kahraman olan bu kişinin, Selim Taşıl ile tanışıklığı vardır ve geriye dönüş tekniği ile anlatıcının geçmişine dair bilgiler verilir. Böylece kimi yerde anlatıcı ve eleştirmen kimi yerde de yazar anlatıcı olarak kendini tanıtan bu kişi, postmodern düzlemde kahraman statüsü kazanır.

Selim Taşı1 'akliye ve asabiye mütehassısı'/psikiyatr İzzeddin Şadan Bey'in üvey oğludur. İzzeddin Şadan Bey'den kalan 'casebook'ta, yazar anlatıcının ilk gençliğinin özellikle cinsel dünyasına ve ilgi duyduğu kişiye dair kayıtlar vardır. Bu kişi Selim Taşıl'ın annesi Müstehase Hanım'dır. Kahraman statüsü kazanan anlatıcının Selim Taşıl ile bu defteri almak için buluşması ve defterin içeriğinden bahsedilmesi anlatının ikinci kurgusunu oluşturur. Heyecan unsuru olarak sunulan bu defter meselesi Kuyu'da çözüme kavuşturulur. İzzeddin Şadan'ın kendisiyle psikiyatrik seans yapmadığı halde yazdığ 1 'casebook', Hilmi Yavuz'un Kuyu'da tuttuğu günlükten izler taşır: "Hilmi Yavuz'un o sabaha ilişskin olarak 'Hatıra Defteri'ne yazdığ notlar: '19 Mayıs 19... Salı: Bu sabah, balkonda kahvaltı ediyorduk. Babam, gözlüğ̈̈nün üstünden bana kötü kötü baklyor. Dün gece eve geç geldim diye, içerlemiş -belli! Şu lânet olası kahvaltıyı bir an önce bitirip kendimi okula atsam hiç fena olmayacak... Fazilet Dadı aşağıdan seslendi 'İzzeddin Şadan Bey geldi,' Amcam gelmiş;... Babam Bu ne hal İzzeddin? diye sordu ..." (s. 205). Fehmi K. gibi bu kurguda da kahraman olan anlatıcı, birçok yönüyle Hilmi Yavuz' dur. Yaşadıkları, çocukluğunun bir kısmını geçirdiği Güneydoğu kenti Siirt, dadısı, eşi ve üvey kızı bizlere hep onu hatırlatır. Birinci kurgusal düzlem Hilmi Yavuz'un Fehmi K.'nın Acayip Serüvenleri adlı anlatısıdır. İkinci kurgusal düzlemde ise Selim Taşıl'ın yazarlığı ve hayat hikâyesi anlatilir.

\section{c) Kuyu}

Zengin bir anlatıma sahip olan Kuyu adlı anlatıda iç içe geçen pek çok olay halkası vardır, bunları rakamsal olarak belirtmek gerekirse;

1. Hilmi Yavuz'un anlatı yazabileceği bir kuyu araması,

2. Hilmi Yavuz'un kuyuyla ilgili gördüğü bir düşü anlatması (s. 167),

3. Hilmi Yavuz'un babası Hikmet Bey ile amcası İzzettin Şadan Bey’e dair çocukluk anısını anlatması (Kalamış'ta evde bir yaz akşamı eğlenceyle geçen yaşananların hikâyesi),

4. Hilmi Yavuz'un evinin karşısındaki otel inşaatını ve annesini anlatması,

5. Hilmi Yavuz'un Evliya Çelebi'yi okuması (Evliya Çelebi'nin kitabındaki Ali Kuşçu'nun Çah-1 Gayya'sının hikâyesi) (s. 176),

6. Sümbül Sinan Efendi'nin gördüğü rüyanın anlatılması (s. 179),

7. Sümbül Sinan'ın gördüğü o büyüleyici rüyayı Şeyh Cemaleddin'e nakletmesi ve rüyanın yorumundan sonra Çelebi Halife'nin onu Allah'ın sevgili kulu olarak tanımlaması,

8. Hilmi Yavuz'un çocukluğunda büyükbabasının konağında kuzenleriyle yaşadıklarını anlatmas1 (s. 182), 
Çocukluğunda büyükbabasının konağının taş avlusunda amca ve dayı çocuklarıyla futbol oynarken top, avludaki su kuyusuna düşer. Hilmi Yavuz topu kuyudan çıkarması için mahallede bir dükkânda çalışan ve kuyular hakkında çok şey bildiğine inandığı Muhammed Emin'i çağırır.

9. Kuyuya düşen topu çıkarmaya çalışan Muhammed Emin'in, İbn Mukanna adındaki dervişle ilgili gizemli bir hikâye anlatması (s. 182),

10. Yetişkin Hilmi Yavuz’un kuyu olarak nitelendirdiği otel inşaatına bakarak elindeki anlatıyı yazmas1,

11. İzzeddin Şadan Bey'in gençlik yıllarında Düsseldorf'ta Fraulein Inge ile ilgili hatıralarını anlatmas1 (s. 194),

12. Hilmi Yavuz'un Güneydoğu'da büyükbabasının yaşadığı konağın avlusundaki kuyuya düşen topu, Pembo Abla adındaki bir kişinin çıkartmaya çalıştığını anlatması (s. 199),

13. Danyal oğlu Hasip'in öyküsünün anlatılması (s. 200): Danyal oğlu Hasip'in öyküsüne göre bir zamanlar iki arkadaş dağlara odun kesmeye gider, geri dönerken bal ve altın dolu küpler bulurlar. Buldukları ganimeti çıkarmak için kuyuya indirilen Hasip, yukarıda duran ve ganimeti alan arkadaşının kurnazlığı ve kötülüğü nedeniyle kuyuya terk edilir. Kuyuda terk edilen ve kuyudan çıkamayan Hasip, kuyuda kuyunun kraliçesi olan Şahmeran ile karşılaşır ve başından geçen birtakım gizemli olaylar anlatilır.

14. Hilmi Yavuz'un annesi ile yengesi Müstehase Hanım'ın Eyüp'te “Can Kuyusu” olarak bilinen bir kuyuya giderek kuyudan gelecek ile ilgili bilgi almak istemelerinin anlatılmas1 (s. 204),

15. Müstehase Hanım'ın, Muhasebeci Neci Bey için yazdığı mektuplardan bahsedilmesi (s. 205) şeklinde siralanır.

$\ddot{U}_{c ̧}$ Anlatı'nın, kurmaca içinde kurmaca anlatılması noktasında oldukça zengin ve çokkatmanlı bir yapıya sahip olduğu sonucuna ulaşılır.

\section{Metnin Yazılıs Sürecini Metnin Konusu Hâline Getirme}

Üstkurmacanın bu kullanımı ile yazar, metnin başından sonuna kadar anlatı metninin nasıl oluşturulduğunun, kurmacayı nasıl gerçekleştiğinin hikâyesini anlatır. Yazar, seçtiği anlatıcının ağzından "okuyucu” ya tahkiye etmenin nasıl yapıldı̆̆ 1 bilgisini verir. Böylece yazma eyleminin kendisi kurmaca metnin içinde kurgulanır.

Üstkurmacada okuyucuya verilmek istenen anlamın/öykünün değeri ikinci planda kalır. Yazar âdeta, oluşturacağı metni kurgularken kullanacağı ya da kullanmak istediği teknikleri yüksek sesle düşünür ve okuyucuyu anlatının içine çeker.

Yazar, okuyucuya anlatıyı nasıl öykülediği, bu süreçte hangi kitaplardan etkilendiği, hangi biçimsel ve teknik sorunlarla karşı karşıya kaldığı ve bu sorunları nasıl çözdüğü, hangi otobiyografik yaşantısını kurmaca düzlemine taşıdığı gibi pek çok konu hakkında bilgi vererek metnin yazılış sürecini metnin konusu hâline getirir. Bir başka ifade ile "Üstkurmacada yazar dolaysız bir biçimde 'roman yazma' işini romana özne olarak seçer.” (McCaffrey, 1982: 182; Waugh, 1996: 40). Üstkurmaca anlatım tekniği ile edebiyatta özneye ve nesneye olan bakış değişir, artık önemli olan konu değil edebiyatın/yazma eyleminin kendisini anlatmasıdır.

\section{a) Taormina}

$\ddot{U} c ̧$ Anlatı'da bakışım ilkesine bağlı olarak kurgulanan hayalî şehir Taormina, yazarın öteden beri ilgi alanında olan kent projelerindendir ve beklentilerine cevap vermeyişinden ötürü ortaya çıkar. "Bir felsefecinin imgelemdeki uzamı nasıl olmalıydı? ... Önce sorunu Biçim(Form) açısından düşündüm... dairesel bir kent olarak hayal etmeyi denedim. Kentlerin kuruluşu üzerine bir şeyler 
okumak gereğini duydum ... Evet, kentlerin kuruluşunu inceledim -ve, açıkça söylemeliyim, bugüne değin kurulmuş olan kentlerin hiçbirinin plani, bana yetkin bir plan gibi görünmedi. Ben, bir kent ideasının ardına düşmüştüm- dolayısıyla, Dünya üzerinde bugüne değin kurulmuş kentlerin tümünü planlarını tek tek incelemiş olmanın bir anlamı olmadığını anladım. Yapılacak bir tek şey vardı - o da kent ideasını benim gerçekleştirmem! Sonunda, idea'nın bir Biçim (Form) değil, (örneğin: Daire), bir ilişki olduğunu anladım. Kent ideası bir ilişki üzerine kurulmalıydl. Düşüne düşüne en yetkin ilişkinin, 'bakışım' olduğuna karar verdim... -Ve sonunda 'Taormina'yı kurdum!' (s. 39-40).

Yazar kurmaca dünyayı/Taormina'yı nasıl kurduğunu açıklayarak yazma tekniği ve eserin oluşum süreci hakkında okuyucuya bilgi verir. "Demek ki, bir kenti imgelemde yeniden kurabilmek için, okumak yetmiyordu. O kentin insanı olabilmeyi ögrenmek de gerekiyordu. Insan kendini kendi imgeleminde yeniden nasıl kurar? Doğrusu çok zor değildir bu, deneyimli biri olarak söylüyorum, kendinize bir model, bir exempla seçersiniz (buna isterseniz, 'mürşid' de diyebilirsiniz), çok kolay olur bu.” (s. 76). Hilmi Yavuz'un dile getirdiği mürşid-mürid ilişkisi yazarın yazın hayatındaki geçen evreler, olgunlaşma süreci ve yazma tekniğinin oluşumu hakkındaki en somut veriler olarak düşünülmelidir. Bu bağlamda yazarın burada kendine bir model, örnek alması; bir başka ifade ile kendisini mürid/köle olarak görüp bir mürşid/efendi seçmesi; yazmaya başlamadan önce kendisinden önceki sanatçıları okuyup özümsediği ve okuduğu sanatçıların ve eserlerin ışığında kendine özgü bir yazma tekniği geliştirdiği imlenir. Bu bakımdan yazarın, yazarlığa başlamadan önce Calvino, Dostoyevski, Moliere, Eşrefoğlu Rumi gibi gerek Batı gerek Türk edebiyatından pek çok sanatçıyı okuduğu ve kalemini geliştirecek birçok kazanım elde ettiği görülür. Böylece okuduğu sanatçılarla özdeşleşerek kendi "sanatçı kimlik”ini nasıl oluşturduğunu anlatır. “... Yavuz için ayna, bilindik yan anlamlarının ötesine kayarak başka bir alana, yaratıcı yazarlığı imleyen bir alana açılır. ” (Erkan, 2016: 1188). Anlatıda geçen "ayna" imgesiyle ise yazar, okuduğu sanatçılarla özdeşleştiği gerçeğini gözler önüne serer: "İnsan, bedensel olarak aynanın içindeki imgesinin içine girebilir mi? Bunun olası olduğunu sanmak yanlıştır. Çünkü, aynadaki imgenizin içine girmek için aynanın arkasına geçtiğinizde, aynadaki imgeniz de kaybolmuş olacaktır. Ama ben, o yaz, tinsel olarak, Eşrefoğlu imgesinin (ayna imgesi) içine girdim. ” (s. 77-78). Burada anlatıc yazar, kendisine o yaz tinsel olarak Eşrefoğlu'nu örnek yani mürşid/efendi olarak seçtiğini belirtirken tinsel bir yaklaşım içinde âdeta Eşrefoğlu Rumi ile özdeşleşir ve bu şekilde yazma sürecine başladığını dile getirir: "O yaz sabahı, daktilomun başına geçtim ve nescafeme süt koymayı unutarak, yazacă̆ım otobiyografik romana başladım. ” (s. 78). Metnin yazılış sürecini ayrıntılı bir şekilde açıklayan yazar, aynı zamanda üstkurmaca tekniklerinden roman yazan bir insanı anlatan kurmaca özelliğini örneklendirmiş olur.

Yazar, kent ideasını tetikleyen unsurlara arkadaşı Erkut'la rastlar. İlkinde, Kıztaşı'nı beyaz bir yelkenliye benzetirler. Viyana'da dolaşırken bir antikacı dükkânın vitrininde gördüğü fildişinden yapılmış küçük fil heykeller diğer ideası olur (s.71). Ona bu hayalleri kurduran yazar, Hilmi Yavuz'dur. Postmodern anlayışa uygun olarak kurmaca biçiminde anlatıya giren bu öykülerin gerçek ya da sadece hayalî oluşlarının belirtilmeyişi bu akımın esere yansımasından ötürüdür. Ayrıca Kıztaşı'nın görüntüsü ve Viyana'da vitrinde görülen fildişinden yapılan heykeller, anlatıda gerçek ile kurmacanın iç içeliğini gösterir. "Konu öykülemek; postmodern çoğulculuğun, gelenekselle avangardist sanat arasında bir ayrım gözetmeyen yapısına da uygundur... postmodern öykü anlatıcısı, öyküyü yansıtmacı bir yaklaşımla anlatmıyor, onun doğru/gerçek olduğunu savlamıyor, tam tersine öyküsünün kurmaca karakterinin altını çizerek yapıyordur bunu..." (Ecevit, 2001: 78).

Arkadaşı Erkut ile Fatih’te ortak tanıdıkları olan Gıyaseddin Ağabey'in seyyar gazete tezgâhı önünde Kıztaşı'nı seyreden Yusuf Horoz, bu taşı beyaz yelkenli olarak düşünür: "Sicak yaz ikindilerinde tezgâha vuran güneşs çoktan çekip gitmişken, uzaktan Kıztaşı'nı bir beyaz yelkenliymiş gibi düşünmek (burada 'düşünmek', 'hayal etmek'le eş anlamlıdır) müthiş hoşuma gidiyordu." (s. 68). Bu beyaz yelkenli, Taormina imgesine vücut vermede belirleyici rol oynar. Tıpkı Viyana' da antikacı dükkânında rastladığı fil heykelciklerinin, Hoca Gıyaseddin Nakkaş'ın Hıtay seferini anımsatması gibi "Yaşamımın 
en önemli dönüşümlerinden birini gerçekleştirmeme neden bu mutlu rastlantıdan elbette -ve öncelikle söz etmeliyim. Bu heykelcikler on taneydi (yoksa on bir miydi?) ve birbirinden ayırt edebilmelerine olanak yoktu. Sanki bir kaliptan çıkmış gibiydiler ve ancak uzamda kapladıkları yerden dolayı birbirlerinden ayrllabilirlerdi... Nitekim daha sonra da, kim bilir kaç kez, o filcikleri seyretmeye gittim ve her keresinde bu filcikler imgelemi klşkrtan gizemli bir aura buldum. Şunu da belirmeliyim ki, o yillarda felsefeci olmaya pek heveslendiğimden olacak bu beyaz, gizemli filciklerin bana Çin' $i$, Maçin 'i (metinde 'Hıtay' diye geçiyor H.Y.) pek belirsiz bir biçimde çağrıştırdıkları bir yana, beni 'bakışım' sorunları üzerinde önemle durmaya götürdükleri de bir gerçektir. Bu filler bakışıml mıydılar? Eldivenler bakışımlı mıydılar? vb. vb." (s. 71-72). Yazar anlatısını nasıl kurguladığını, hangi teknikleri kullandığını ve hangi objelerden yararlandığını belirterek anlatının yazılma süreci hakkında okuyucuyu bilgilendirir. Beyaz bir yelkenliye benzettiği Kıztaşı ve filcikler ona Taormina'yı hayal ettirmekle kalmaz, kurgulanan bu imge kentte bakışımlara da neden olur. Yusuf Horoz'un anlatısındaki obje, heykel ve birtakım olaylar okumuş olduğu Hoca Gıyaseddin Nakkaş'ın Acaib 'ül Letaif'inde yer alan obje, heykel ve olaylarla bire bir örtüşür. Ayrıca bütün hazırlıklar anlatıyı, roman yazan bir kişsiyi anlatan kurmaca hâline getirir. "Postmodern anlatının ana kişisi, bir figürden diğerine dönüşüp duran biridir, belirli bir kimliği yoktur.” (Ecevit, 2001: 77). Yusuf Horoz, Giyaseddin'den bir fotoğraf olarak bahseder. Bu tanıtımda, ona daha sonra yükleyeceği karakter özelliklerinin ipuçları vardır: "Glyaseddin de bir fotoğraftt. Şimdi işte imgelere bir yenisi ekleniyor. Ve bütün fotoğraflar gibi, hem düzanlam hem de yananlam olarak çifte kişilikle var oluyor. Glyaseddin'in de, çifte kişilikli olarak böylesine bir çifte yaşamı vardı. Kuşkusuz, hepimiz biraz böyle değil miyiz? ... Şimdi, Gıyaseddin'in başkanlığındaki bir delegasyonun 'Taormina'ya gelişine ilişkin imgenin öyküsünü anlatmalıyım size...” (24-25).

Yusuf Horoz'un roman yazarken kullandığı bir başka malzeme ise Giyaseddin olarak tanımladığı fotoğraftır. Bu fotoğraf yazar için ilham kaynağı olan yeni bir imgedir aslında. Burada yazar, fotoğraftaki kişiye çifte kimlik yükler. Onu önce Taormina'ya ziyarete gelen delegasyon heyetinin başındaki kişi, sonrasında ise Acaib'ül Letaif adlı sefaretnamedeki elçi rolünde tanımlar.

Yazar, yazma tekniği hakkında bilgi verirken karşılaştığı birtakım güçlüklerden de bahseder: “...Taormina'yı kurarken çok ciddi ve bazan aşılmaz gibi görünen zorluklarla karşılaştım ... Ne zaman bakışım ilişkisine göre bu uzamı ('Taormina'yl, kenti) belirlemeye kalksam, karşıma birtakım lojik engeller çıkıyor, bu ilişkiyi olumsuzluyordu. Onun için, bakışımdan ödün vermeden, izomorfizmi, ayırdedilmezlerin özdeşliği vb. gibi birtakım başka ilişkileri de (bana göre bunların tümü, bakışım ilişkisinin türevleriydiler) kattım işin içine. Bir felsefeci, kent planlamacıllğına soyunursa ne olur? İşte öyleydim ben de -kenti, bir idea'ya göre kuruyordum. Onun için de elbette birtakım felsefe kavramlarından, ilişkileri gösteren kavramlardan yola çıkacaktım." (s. 41).

Diğer taraftan yazar, Taormina'yı oluştururken gerçek ile kurmacanın iç içeliğinden yararlanır. Yazarın Bodrum'un Kumbahçe Mahallesi'ndeki yaşadığı evin bahçesinden gördüğü manzara aslında Taormina betimlemesiyle pek çok açıdan benzeşir. Yazar öncelikle bir kent imgesi kurabilmek için yalnızca bundan önce kaleme alınmış eserlerin okunmasının yeterli olmadığını, aynı zamanda o kentin insanı olabilmeyi öğrenmenin gerekliliğini belirtir. Anlatı kurgusu oluştururken yalnızca Batının şövalye romanlarından değil, kendi geleneğinden de hareket edilmesi gerektiğini belirtir: “...ben de, kendi imgelemimde kendimi yeniden kurarken, bu kez şövalye romanlarından değil de, modern romanlardan yola çıkacaktım. Buna, yaşam deneyimi katmanın gerekli olduğuna, Kumbahçeli o yaşlı bakkalı tanıdiktan sonra karar verdiğimi söylemiştim. O dükkâna sabah, ekmek ve gazete almaya bir Calvino ya da Dostoyevski kişisi olarak değil, Eşrefoğlu Rumi'nin Menâkıb'ından yola çıkarak gitmek daha doğru olacaktı." (s. 76). Yazar anlatının ilk sayfasında yaptığı mekân tasvirini son sayfada da yineler. Anlatının ilk sayfası ile son sayfasını aynileştirerek anlatılan bölümlerin hangisinin roman, hangisinin roman denemesi olduğu belirsizleştirirlir; böylece gerçek ile kurmaca yaşam arasındaki ilişkiye vurgu yapar. 


\section{b) Fehmi K.'nın Acayip Serüvenleri}

Fehmi Kavkı yalnız yaşayan biridir. Ancak yazar bir anlatı karakteri olan Fehmi Kavkı'nın, yalnız bir karakter olarak yer almasını istemediğini bunun için Anette adında bir bayan karakteri anlatıya dâhil etme planını, iletişim içinde olduğu okuyucuya anlatır: "Fehmi Kavkı'nın yalnızlı̆̆ına izin vermeyeceğimi sizlere, siz okurlara açık açı söylemekten gurur duyuyorum. Hayır, Fehmi Kavkı'nın yalnız yaşamasına kesinlikle tahammülüm yok! Öyleyse yapılacak şey, Fehmi Kavkı'yı Anette ile tanıştırmak ..." (s. 88). Okuyucu ile sürekli iletişim içinde olan yazar, eserin kurgulanışı ve yazma tekniği hakkında ona sürekli bilgile verir. Fehmi Kavkı'yı Anette ile tanıştırmayı planlaması ve böylece Fehmi Kavkı'nın yalnızlığını gidermek için kurguyu nasıl geliştireceği aşamasını onunla paylaşır. "Siz anlatı kahramanlarının annelerine bakmayın! Çoğu yalancıdır onların. Oğullarının, Anette gibi kızlarla iliş̧ki kurmasından tedirgin olduklarından, tıpkı gerçek yaşamda olduğu gibi, kızları üçüncü kişilerin gözünde küçük düşürecek her türlü benzetmeye başvururlar.” (s. 88). Yazarın, anlat1 karakterleri hakkında okuyucuyla dertleştiği, onları eleştirdiği ve çeşitli yönlerden değerlendirdiği görülür: "Fehmi K. 'nın işyeri, evinden biraz uzaktı; ama yine de, yürünebilir bir uzaklıktı bu. Onun içindir ki, ben, Fehmi $K$.'nın evinden çılkp işyerine yürümesi gerektiğini düşündüm. İstesem pekâlâ, otobüse ya da dolmuşa da bindirebilirdim; -gördüğ̈̈müz gibi yapmadım bunu! ... Örneğin, Orta Avrupa romanların 1920 'lerde ürettiği tiplerden biri olarak düşünseydim Fehmi K.' 'yl, belki de o yaz günü palto giydirir, sokağa öyle çıkarırdım. O zaman da belki otobüse bindirmek gerekirdi kahramanımızı. Fehmi K. 'yı öyle bunalımlı bir tip olarak tasarlamadığım için bu yollara başvurmadım. Bunun böylece bilinmesinde yarar var..." (s. 90).

Yazarın anlatısını, yazının kendisini ve tekniğini paylaşması Postmodern romanın ve bu bağlamda üstkurmacanın en önemli özelliklerindendir. Üstkurmaca anlatıda yazar, her ne kadar okuyucuyu metne dâhil ederek bu düzlemde kurguyu sunsa da romanın başından sonuna kadar anlatıda kendi varlığı baskındır. Yazar nasıl bir roman yazacağını planlar, düzenlemeler yapar ve yazma tekniği hakkında bilgi verir. Zaman zaman okur adına söz dahi alır: “... bir okur olarak, yazara şunu söylemek istiyorum: Fehmi K. 'nın bunalımlı bir tip olmadı̆̆ını belirttikten sonra, bunu bir kez de, öykülemenin içinde Fehmi K. 'ya söyletmenin ne anlamı var? Siz anlatı yazarları, kötü eleştirmenleri iyi okurlara yeğlediğiniz için ayırdında görünmüyorsunuz, ama sizi öven kötü eleştirmenler bu tür yanlışlıklarınızın ayırdında olmadıkları için, sizi yeren iyi okurlara ayırdına varılacak çok şey bırakırlar. Bunlardan biri de budur." (s. 91) Yazar, Fehmi K.'y1 bir kurmaca karakter bilincinde olduğunu hissettirerek ona söz hakkı tanır. Böylelikle hem okuyucunun dikkatini ölçmek hem de üstkurgusal bakımdan yazma tekniği hakkında okuyucuya bilgi sunmak ister.

"Bizim için, ancak, algıladı̆̆ımız sürece varolurlar anlatı kahramanları. Belki de, gerçek yazarlık, algılamadı̆̆ımız süre içinde onların ne yaptıklarını yazabilmektir... Bana sorarsanız, bir roman gücünü dışarda (romanın dışında) tutmayı başardığı romanlardan alır. Ama hiçbir romancı Dostoyevski, Kafka, Hermann Broch ve İtalo Calvino gibi pek büyük romancılar da içinde olmak üzere,kendilerinden önce yazılmış romanların tümünü dışarda bırakabilme gücünü gösterememişlerdir. Bu böylece biline..." (s. 99). Yazar, yazın tekniğinin oluşumunda, daha önce okuduğu büyük romancıların katkısı olduğunu vurgular. Derin bilgi birikiminin oluşumunda okuduğu Batı sanatçılarının etkisinin olduğunu ve bu etkiyi roman yazma sürecinde de dışarda bırakmadığını belirtir. Şiirleri için sık sık dile getirdiği usta çırak ilişkisine anlatı yazarlığında da inandığını dile getirir.

Yazar, kendi yazın tekniği hakkında bilgiler sunmaktan ya da açıkça dile getirmekten çekinmez: "Şimdi işte bendenizin de bir anlatı yazarı olarak yaptı̆̆ım tastamam budur: Varlı̆̆ımı duyurmaktan çekinmedim. Ama doğallıkla okurun ve eleştirmenin de varlıklarını duyurmalarını istediğim söylenemez. Şurası kesin: Yazar olarak, anlatının kişilerine egemen olabiliyorsunuz, ona varlı̆̆ınızı duyurabiliyorsunuz, ama okur ya da eleştirmenin kişiliğinde yapamıyorsunuz bunu... Onların, benim özgür istencim dişında diledikleri gibi metne müdahale ettiklerine şimdiye değin çok tanık olduğunuz." (s. 105). 
Hilmi Yavuz, bu anlatının yazarı olarak anlatı kahramanları üzerinde varlığını hissettirdiğini ancak okuyucu ve eleştirmenin üzerinde bir egemenliğinin olmadığını, onların anlatıya istedikleri gibi özgürce müdahale edebileceklerini belirtir. Bu durumda yazar, aslında postmodern tarzda üstkurmaca bir anlatı yazdığını; anlatıya okuyucuyu, eleştirmeni ve böylece çok sayıda anlatıcıyı dâhil ettiğini vurgulamış olur. Böylece anlatıcı çoğulculuğu ile beraber anlatı kahramanlarından kimin anlatıcı, okuyucu ya da eleştirmen olduğu gerçeği zihinlerde soru işareti olarak kalmaya devam eder. Anlatıcının sürekli konum değiştirmesi ile anlatının hem bir sohbet havasına taşınmasına hem de anlam karmaşası aracılığı ile oyuna dönüşmesine olanak sağlanır.

Hilmi Yavuz anlatıcı rolünü yalnızca anlatıcıya değil; zaman zaman okuyucu ve eleştirmene de verir. Bu durum aynı zamanda şu gerçeği gösterir: Hilmi Yavuz anlatıda yazar, anlatıcı, eleştirmen ve hatta okuyucu rolünde yer alır. Bu tutum postmodern anlatının ve üstkurmaca tekniğinin doğal bir sonucudur. Yazar okuyucunun zihninde anlam karışıklığ yapmak istediği için bunu bilinçli bir şekilde tercih eder. Tabi ki bütün bunların gerisinde yazar, anlatının belirleyicisinin yalnızca kendisi olduğu vurgusunu yapar. Böylelikle yazar, anlatı kuramını ortaya koyarak anlatısını nasıl oluşturduğu hakkında bilgi verir. Yazma tekniğinin değiştiğini, klasik ve modern edebiyatın ötesinde postmodern yazın anlayışı ile birlikte sanatçıların artık yazı'nın kendisini anlatmaya çalıştıklarını belirtir. "Tolstoy'un Bezukhov'unun gözlükleriyle başlanan bir anlatıyla, İtalo Calvino'nun Emir İsoarra'sının gözlükleri ile başlanan bir anlatı arasında dağlar kadar fark vardır. Evet, dağlar kadar... Bu, en azından on dokuzuncu yüzyıl romanıyla yirminci yüzyıl romanı arasındaki farka tekabül eder...” (s. 128). Değişen ve gelişen çağın bir sonucu olarak edebiyatta artık söylenmemiş bir konu kalmadığı ve böylece edebiyatın kendisinin konu edindiği ifade edilir.

Yazarın metnin yazılıș süreciyle ilgili okuyucuya birtakım bilgiler sunarak bu metodu metnin konusu hâline getirir: “...Fehmi K. ve Anettte, bu kez, belirli bir ilgiyle dinlediklerini göstermek durumunda hissettikleri için kendilerini, pek mutlu sayllmazlar. Hangi 'belirli ilgi', Tanrı aşkına? Bütün bu 'belirli'leri benden başka kim belirleyebilir? Ben, yâni anlatıcı... Bu anlatıda benden başkalarının $d a$, örneğin, okurun, ya da eleştirmenlerin anlatıcı olarak boy göstermelerine izin verdiysem, ne yani, kötü mü ettim? Aslında, bu anlatı neyi anlatır? Diye sorsanız da söz konusuysa, (çünkü, burada sadece anlatıcı'ları değil, okurları da tasarlamak durumundayım), yanitım, bu anlatı, anlatı'yı anlatır olacaktır. Size şunu söyleyeyim ki, hiç de alçakgönüllü davranmıyorum burada: -Yazarlıkta en zor olan, anlatı'yı anlatmak'-tır. Yoksa herkes, bir şeyler anlatabilir okur da ağzı açık ayran budalası gibi, bu bir şeyleri gerçekten bir şey sanabilir. Örnekleri çoktur bunun. 'belirli ilgi', şu: Fehmi K. ile Anette, Selim Taşıl'ın müzik söylevini 'belirli bir ilgi' ile dinliyorsa, bu anlatı yazarının, İstanbul Festivali 1990'da, Aya Irini'de dinlediği I Musici konserine ilişkin olarak Festival programinda aktardiğ yukarıdaki söylevi çok beğenmiş olmasındandır. Doğallıkla anlatı yazarı da, konseri çok beğenmiştir. Anlatının bu bölümünü de, sıcă̆ı sıcağına, I Musici konserinden sonra yazmış olmalıdır, -tabii Festival programına bakarak... Anlatı kişileri niçin, başka söylemlerden aktarılan sözlerle konuşurlar da, genelde birkaç uyanık okur dışında, hiç kimse bunun ayırdına varmaz? Örneğin, bu anlatıda da, öyle olmuştur." (s. 122-123). Yazar; anlatıyı, anlatının içeriğini, anlatıcıyı ve okuyucuları nasıl belirlediğine ve her şeyin kendi kontrolü dâhilinde geliştiğine dair bilgiler sunar. Bu anlatının bir kurmaca olduğu ve bu kurmacanın sınırlarının ancak kendisi ile belirlenebildiği ayrıca bu anlatının kendi gerçek yaşantısından, bir başka ifade ile Hilmi Yavuz'un kendisinin gittiği müzik konserinden bir kesit alınarak yazıldığı ihtimalini zihinlerde uyandırır. Burada hem yazarın yazma tekniği hakkında bilgi verilmesi hem de roman yazan bir insanı anlatan kurmaca olması ile anlatı ayrıca üstkurmaca boyut kazanır.

Üstkurmaca anlatının önemli özelliklerinden olan “anlatıyı anlatmak” Fehmi K'nın Acayip Serüvenleri'nde pek çok kez "Yazarlıkta en zor olan, anlatı'yı anlatmak'-tır." (s. 123) şeklinde dile getirilir. Hilmi Yavuz bu anlatıda genel olarak olay örgüsünün bulunmadığını ve asıl amacın anlatının kurgulanışı hakkında bilgi vererek anlatının anlatısını anlatmak olduğunu belirtir. 
Fehmi K'nın Acayip Serüvenleri'nde, metinlerarası ilişki ve buna bağlı olarak parodi ve pastişten yararlanılır. Postmodern romanlardaki pastiş, üstkurmacanın alt kategorisi olarak değerlendirilir. Yazar kendinden önceki eserlerin sanal dünyasında gezintiye çıkar ve devşirdiklerini anlatı kurgusuna katar. "Pastiş, postmodernist romanda biyografi, otobiyografi, bilimsel metin vb. söylem alanlarına ya da destan, masal, halk hikâyesi, söylence gibi türlere özgü üslûp ögelerini, söyleyiş tarzlarını metnin temel üslûbu edinmek şeklinde kullanılmaktadır." (Sazyek, 2002: 500) Hilmi Yavuz, Fehmi K. 'nın Acayip Serüvenleri'nde metinlerarasılığın bu işlevinden sıkça yararlanır. Zaten anlatı, bir parodi örneği olarak tasarlanmış ve okuyucunun dikkatine sunulmuştur. Metinlerarası ilişkilerde bunu görmek mümkündür. Üstkurmaca metinde yazar, metinlerarasılıktan yararlanarak metin içi öyküler oluşturur, böylece kurmacada gerçeklik düzlemine geçilir. Üstkurmaca metinde ana öyküyle metin içindeki öykü katmanları birbirine karışır. Bu yüzden okuyucu, gerçek ile kurmaca arasındaki ayrımın farkına varmakta zorlanır.

$\ddot{U}_{\zeta}$ Anlatı' da da Hilmi Yavuz, Franz Kafka'nın Değişim adlı romanında Gregor Samsa'nın böceğe dönüşmesinden Tolstoy'un Savaş ve Barış'indaki Bezukhov'un gözlüklerine, onlardan Sartre ve Rumelhard'a uzanan bir metinlerarası bağ kurar: "Fehmi K., bir küçük banka memuru olarak tasarlandı ve şimdilik kendisi bu tasarıma bağlı kalmay sürdürüyor. Size söyledimdi, ama Fehmi K., 16 Haziran günü doğmuştur. Bu, onu 16 Haziran günü tasarladım demektir. Niye 16 Haziran diye sorarsanız, size, Joyce'un Ulysses' ini salık veririm. Leopod Bloom'u anımsayınız lütfen. Bu küçük Irlandalı Yahudiyi ve 16 Haziran 1904 gününü... Anette, işte öyle, biraz Bloom'un karısı Molly'i andırlyor. Yoksa, Şato'daki Frieda'yı mı? Kimi andırırsa andırsın, ben onu hep Beyaz Geceler'deki Nastenka gibi düşünürüm." (s. 111) Anlatıcı bir başka yerde ise Fehmi K.'nın, Kafka'nın Değişim adlı romanından Gregor Samsa'nın aynasından çıkan kişi; Anette'nin ise bir başka anlatı veya romandan çıkmış biri olarak nitelendirir: "Anlatı kişilerinin kimlikleri son kertede daha önce üretilmiş olan yazınsal bağlamlar tarafindan belirlenir. Her anlatı kişisi, bağlamsal bir üstbelirlenim'dir...” (s. 141). Hilmi Yavuz, Fehmi K. 'nın Acayip Serüvenleri'nde pastişi bütüncül biçimden uzak, konu akışına ve kahramanlara bağlı olacak şekilde kullanır. Aynı zamanda yazar, anlatısını ve kendi karakterlerinin kimliğini oluştururken daha önce okumuş olduğu yazar ve romanlardan faydalandığını dile getirir.

Yazar, çocukluğunda Güneydoğu Anadolu'da kuzenleriyle bağa gittiği ve bağdan dönerken yamaç aşağı atının tökezleyip düşmesiyle ilgili anısını anlatmasını teknik bakımdan gerekli gördüğünü belirtir. Kurgunun bir başka halkasındaki Fehmi K. ve Anette Hanım ile ilgili anlatıya yeni kişiler ekleyebilmesinde bu anıların teknik bakımdan işlevler üstlendiğini belirtir. (s. 145)

Hilmi Yavuz romanının yazılma sürecinde okumuş olduğu eserlerdeki kişi ve olaylarla gündelik hayattaki kişi ve olayları birleştirdiğini ifade eder: "Edebiyat, özellikle de roman okuma (ve, daha sonra da, yazma) tutkusu, yaşamımı kötü, çok kötü bir biçimde etkilemiştir. Edebiyat uğraşının, daha başından beri lânetlenmiş bir uğraş olduğunu öğrendim giderek... Gündelik yaşamdan bir başka dünyaya düşmüş, ya da atılmıştım (Heidegger: 'Dünyaya atılmışlık', diyor) Bu dünyada her şeyin 'kurmaca' olduğunu, gerçekliğinse ancak vraisemblable biçiminde dile getirilebileceğini ögrreniyordum -ve herkesi roman idealarl dünyasındaki Form'lar ya da İdea 'ların dünyadaki benzerlerine göre adlandirlyordum. Şu M. Homais idi (bizim mahalledeki eczacı), öteki M. Birotteau (Bitişik köşkte oturan ıtriyat fabrikatörü ... Fiziksel ya da tinsel benzerlikler söz konusu değildi burada." (s. 148-149). Burada aynı zamanda gerçek ile kurmacanın iç içeliği görülür. Anlatının kurmaca dünyasında yaşayan yazar, bir süre sonra gerçek dünyadaki kişi, olay ve varlıkları kurmaca dünyasındaki form ve idealara göre şekillendirdiğini ve ilişkilendirdiğini ifade eder. Bu durumun roman okuma ve yazmanın tutkusu sonucu ortaya çıktığını belirten yazar, bir süre sonra anlatı dünyasının gerçek dünya olarak algılandığını ve yaşanılan bu dünyanın ise gerçekte idealar ve formlar dünyasının yansıması olduğu belirtir. 


\section{c) Kuyu}

Anlatı ile mekân arasında bir ilişki olmasını amaçlayan yazar, anlatısını nasıl ve nerede yazacağına dair birtakım bilgiler sunar: "Öyküyü yazmadan önce, uzun uzun düşündü ve sonunda karar verdi: Bu anlatıyı bir kuyuda yazacaktı! ... Önce ve kuşkusuz, anlatılanların yazllabilmesine elverişli bir kuyu aramak ve (elbette bulmak!) durumundaydı. Sonra, bu kuyuya yazı masasını ve daktilosunu indirmek için gereken düzenekleri kurmak gerekti. Kuyunun aydinlatılması da söz konusuydu elbet, ama Hilmi Yavuz bunu önemsemedi. Kuyunun, günün belli saatinde kaçınılmaz olarak günışığı alacağını varsaylyordu." (s. 165). Hilmi Yavuz, planlamalarını yaptıktan sonra anlatısını yazabilmek için bulunduğu kentte uygun bir kuyu aramaya başlar. Aslında yazardaki bu kuyu merakı çocukluğuna dayanır. Güneydoğu ilinde büyükbabasının konağının avlusunda biri tatlı diğeri acı sulu iki kuyu bulunur. Hilmi Yavuz'un avluda top oynarken toplarının sürekli düştüğü "cennet ve cehennem" olarak nitelendirilen bu iki kuyular ona her zaman gizemli gelmiştir (s. 182- 188).

Hilmi Yavuz anlatısını yazmak için bulduğu kuyunun özelliklerini görmek için araştırma yapar. $\mathrm{Bu}$ araştırmada beline bağladığı halat ve halatın bulunduğu siyah plastik poşet gibi malzemelerle kuyunun dibine iner. Oradan gökyüzünün nasıl göründüğünü ve içine bir masa-sandalye sığacak kadar genişliği olup anlatı yazmak için uygun olup olmadığını inceler. Yavuz'un çocukluğunun geçtiği havuzlu evin bahçesinde sarmaşıklar, çiçekler ve baygın kokusuyla bahçeyi dolduran hanımelleri bulunur. (s. 172). Anlatısını yazmak için tercih ettiği kuyu ise onun bilinçdışının bir yansıması ve çocukluğa tekrar dönme isteğini gösterir: "Ben, kuyuların siğ, aydınlık (ve manzaralı) olanlarını severim. Kuyunun dibinden yukarıya baktığımızda bir ă̆acın dalını kuyu ăgzına eğilmiş görmek ve eğer bu bir hanımeli ă̆acıysa, çiçeklerinin kuyuya düşü̈ğ̈nü duyumsamak... (s. 174) Kuyu ile çocukluğunun geçtiği ev arasında büyük benzerlik söz konusudur. Kuyu bilinçdışının derinlikleridir.

Hilmi Yavuz'un anlatı yazmak için seçtiği aydınlık ve sığ olan kuyu aslında anlatının "karanlık ve derin" (s. 181-182) olmasını sağlayacaktır. Yazar anlatının karanlık ve derin olması gerektiğine çocukluğunda Güneydoğu ilinde büyükbabasının konağının damında yatarken gece karanlığında bile y1ldızlarla kaplı sonsuz gökyüzünde ve geceyi anımsar. "O yıllarda 'anlatı' sözü bilinmiyordu henüzve Hilmi Yavuz, 'roman' (diye düşünmüşü), 'roman, derin ve karanllk olmall.' Isste öyle bir roman yazacaktı ..." (s. 182)

Anlatıda Hilmi Yavuz, Evliya Çelebi'yi okur. (s. 176) Evlerinin önünde yapılan dev otel inşaatının çukurunu, Evliya Çelebi'nin eserinde geçen "Gayya Kuyusu”na benzetir. Buradan hareket ederek yaşamın aslında bir dil oyunu olduğunu dile getirir: "Yaşam, bir dil oyunundan başka bir şey olabilir mi? Öyleyse niçin, örneğin, neden her şeyi yeniden yazmayı denemeyelim? Yeniden adlandırmayı?" (s. 177-178). Üstkurmaca anlatıların en önemli özelliklerinden biri, daha önce kaleme alınan metinleri tekrar yazmak, metnin nasıl yazıldığını okuyucuya sunarak yazma tekniğini ortaya konulmasıdır. Burada "dil oyunu" ile yazarın yaptığı kelime oyunları, okuyucunun algısını yanıltmaya çalışan çoğulcu anlatıcı ve yine okuyucunun dikkatini ölçmeye çalışan ifade değişiklikleri, yeni mekân ve nesne tanımları gibi unsurlar kastedilir. $\mathrm{Bu}$ unsurlar ile anlatının derinliklerindeki mesaj1, okuyucunun tıpkı bir kuyucu gibi bulup çıkarması beklenir. Dolayısıyla Hilmi Yavuz'un okuyucularına büyük iş düştüğü görülür. Yavuz bu anlatısında Rilke'nin "Kuyular, sessiz, karanlık, dibi çiçekli kuyular! Nilüferler kuyu diplerinde soluyorlar; 'ah, ey Tanrım, benimse üzerimde çatı yok ve yağmur gözlerimin içine yăğyor. "” (s. 192) söyleminden yararlandığını belirtir. Yazar, bu ifadelerle "ölüm”ün tanımlandığına dikkat çeker ve böylece kendi ölümünü yaşamak ve betimlemek ister.

Yazar, anlatının kurgusunda yer alan Danyal oğlu Hasip'in öyküsünün, Almanya'da yaşayan elli-elli beş yaşlarındaki bir işçinin anlattığı öykünün 1982 yılında yapılan bant kaydından alındığını ve bu öykünün büyük oranda 1001 Gece Masalları'ndaki Şahmeran öyküsünden alındığını belirtir. Yazarın öyküsünü nasıl oluşturduğu ve kurgunun yazma süreci noktasında 1001 Gece Masalları'nda geçen Şahmeran öyküsünden yararlandığg bilgisini verir (s. 200-203). 


\section{Kahramanın, Anlatıcıya Seslendiği Bir Kurmaca Olması / Yazar ile Kahramanın İletişim İçinde Olması}

\section{a) Taormina}

Yusuf Horoz'un kendini Taormina'da hayal ettiği sırada, anlatının kahramanlarından Gıyaseddin'in bir anda belirip yazarına seslendiği fark edilir. Bu durum kurmaca dünyadaki bir kahramanın, gerçek yaşamda anlatıyı kurgulayan yazarla iletişime geçtiğinin göstergesidir:

“' 'Taormina'da kural budur: Parça, bütünün yerine geçer!.. İşte bu yüzden, pencereden yelkenlileri süzülüp giderken gördügümde, içimi çekip 'yelkenliler' demiştim ki, Glyaseddin 'in

-Metonimi değil mi hocam?

Sözüyle irkildim. Ne zaman gelmişti buraya Glyaseddin? Ve neden ben 'yelkenliler' diye, çok hafif sesle, belli belirsiz mırıldandiğımda, bana

-Metonimi değil mi hocam?

Demişti?"'(s. 24)

Anlatıda Gıyaseddin bir fotoğraf olarak yer alır ve onun hem düz anlam hem de yan anlam arasında çifte bir kimlikle işlendiği görülür. “... yananlam ile düzanlam arasında bir yırtılmaya, bir ikiliğe uğramış değil miyiz?” (s. 24) ifadesiyle sosyal hayat içinde insanın yaşadığ 1 kimlik karmaşasına, iç ben ile dış ben'in çatışmasına değinilerek insanın çoğu zaman kendisinin ayırdına dahi varamadığı, çifte kimlik olgusu üstkurgusal olarak işlenir.

\section{b) Fehmi K.'nın Acayip Serüvenleri}

Yazar Hilmi Yavuz'un anlatı kahramanı Selim Taşıl ile iletişime geçer: “...benim bu anlatının yazarı olarak Selim Taşıl ile olan yakın arkadaşlı̆̆ımla ilgisi vardır. Selim, bir gün, üvey babasının, Dr. İzzettin Şadan Bf.'nın bütün hastalarına ait 'medical casebook'lar düzenlediğini söylemişti lâf arasında. Sizin anlayacağınız, doktor, hastalarına ilişkin düzenli dosyalar tutmuştu ve büyükbabam da hastası olduğuna göre, elbette onun da bir 'casebook'u olacaktı! Selim'den rica ettim; -beni kırmadı ve birkaç gün sonra, büyükbabama ait dosyayı getirip elime tutuşturdu.” (s. 124-125).

Yazar kendi zihninden geçenleri, anlatı kahramanı olan Selim Taşıl'ın bildiğini söyler. Bu durum anlatı kahramanı ile yazarın iletişim içinde olduğunu gösterir. Selim Taşıl elinde, yazarın ilk gençlik yıllarına dair gizli anılara ait bir dosyanın bulunduğunu söyler (s. 152). Anlatıda bir kahramanın, yazarın bilinçdışına itilmiş olan birtakım duygu, düşünce ve yaşantıları bildiği ve bunu yazara açıkça sunduğu görülür. Selim Taşıl, yazarın çocukluk yıllarında Kalamış’taki köşkte Müstehase Hanım ile kızmabirader oyunu oynamaları sırasında hissettiklerini bilir. Bu duyguların utancını yaşayan yazarın "gözümün önünde sonsuz sarı kumlarıyla tenha deniz kıyıları açıllyordu" (s. 153) ifadesi, onun bulunduğu ortamdan uzaklaşma ve kendisini güvende, mutlu ve huzurlu hissettiği anne karnına kaçış isteği biçiminde yorumlamak olanaklıdır.

Anlatı kahramanı Selim Taşıl, yazara verdiği dosyanın/defterin içinde Kalamış’ta o güne ait bir de fotoğraf vardır. Yazar, bu fotoğrafin düş mü gerçek mi olduğunu bir türlü ayırt edemediğini belirtir: "Bu bir düs müydü, yoksa gerçeklik mi? Bu fotoğraf, kurmaca bir fotoğraf mıydl, yoksa gerçekliği imleyen bir fotoğraf mı? Bilemiyorum." (s. 154). Yazar, anlatının her ne kadar kurmacadan ibaret olduğunu belirtse de okuyucunun zihninde bir gerçeklik algısı oluşturmaya ve okuyucunun zihnini karıştırmaya devam eder. Yaşanılan şey bir oyun olduğuna göre Hilmi Yavuz, oyunu kurallarına göre oynamayı başarabilmiştir. 


\section{Kolaj/Montaj}

Kolaj/montaj kimi zaman gerçek kimi zaman kurmaca yaşamdan alınan deneme, öykü, masal, tiyatro kesiti veya bunların parodisi ya da geçmiş ve gelecekten bir an'a veya bir düşe metin içinde yer verilmesidir. Kolaj, metni oluşturan anlatı parçalarının kurgulanmasını sağlayan bir araçtır. "Anlatıcının metindeki varlığının en aza indirgendiği bölümlerdir bunlar. Tek bir biçeme sadık kalınarak yazllmayan, dokusunda avangard biçim denemelerine yer veren tüm kurmaca metinlerde olduğu gibi, anlatıcının, egemen, kişisel ve nesnel anlatıcı tutumları arasında gidip geldiği bir metindir" (Ecevit, 2008: 151). Aynı zamanda kolaj, dümdüz giden herhangi bir hikâyeyi tekdüzelikten kurtarır ve ona üçüncü bir boyut kazandırır. Kolaj ile birlikte geçmiş, gelecek ve şimdiki zaman parçacıkları ve birbiriyle ilgisiz gibi görünen anlatılar belli bir anlam doğrultusunda yan yana getirilir.

Kolaj tekniğine anlatının yapısını kurmak, güzelleştirmek, güçlendirmek, anlatıya yeni bir biçim kazandırmak ve felsefi bir boyut kazandırmak için başvurulur. Bu anlatı tekniği bir yazıyı, bir sözü değiştirmeden ya da kısmen değiştirerek sezdirme biçiminde de kullanılır. Böylece metinler arasında bir bağ kurulur ve kurmacanın gerçekliğine katkı sağlanır.

\section{a) Taormina}

Kolaj metinde verilmek istenen duygu ve düşünceyi destekleyerek bunların anlaşılmasına, anlamlandırılmasına yardımcı olur. Taormina' da yazarın zaman zaman yazdıklarını başka metinlerden yaptığı alıntılarla desteklediği görülür: "Ben sana zencefili suya katmanı öneririm: Kur'an, Dehr Suresi LXXVI, 17: 'Ve cennettekilerin bir kadehle susuzlukları giderilir ki, içindeki içilecek suya zencefil karıştırılmıştır. ,” (s. 26).

Taormina'da “Acaib'ül Letaif”, adlı sefaretname ile güçlü bağ kurulur. Eserde değinilen metnin gerçeğiyle örtüşür nitelikte olduğu görülür. Hilmi Yavuz, Taormina' da kurduğu bütün bakışımların temeline bu sefaretnâmeyi koyar. Bakışımın uzantısı olarak karşılıklı verilen adlar ve onlarla birlikte kaydedilen motiflerde kolaj ilişkisi netleşir. Bu kullanımlarda Batı ve Doğu'nun bakışımlı oluşları yazarın dikkat ettiği husustur. Örneğin anlatıda Guido'nun bahsettiği zencefil çayını daha sonra Doğu mistisizmini temsil eden karakterlerden bakkal Alaeddin Hoca içer: "Taormina'da tanıdıklarından birinin Guido Ceronetti olduğunu söylemedimdi değil mi? Guido uğradı ve bana zencefil çayını salık verdi... dediklerini sözcüğ̈̈ sözcü̈̆üne anımsıyorum... Ben de Guido'ya yanıtı geciktirmedim, o da acaba benim söylediklerimi sözcüğ̈̈ sözcügüüne anımsıyor mu? Anımsaması gerek, çünkü şöyle dedim: 'Ben sana zencefili suya katman öneririm: Kur'an, Dehr Suresi LXXVI, 17: 'Ve cennetliklerin bir kadehle susuzlukları giderilir ki, içindeki içilecek suya zencefil karıştırılmıştır.” (s. 26)

"Eski Bodrum'da, sabahları gazete almaya çıktığımda yaşlı bakkaldan (yaşlı ve sakallıydı) ekmek alırken Bursa'da, İbn Musa'nın 'somunlar, müminler!' sesini duyan Eşrefoğlu Rumi gibi duyumsuyordum kendimi. Dükkânın bir köşesinde, tüpgazın üzerinde sürekli çay kaynatıyordu (Hayır! Bildiğiniz çay değil, zencefil çayıydı bu) ve yaşlı bakkal, hurma yiyerek bu çaydan içiyordu... (adı Alaeddin Efendi idi galiba ve galiba, camide imamlık yaptığ için Alaeddin Hoca diye biliniyordu) bana, hep bir şeyler gizleyen, ya da herkese söylenmesi yasak olan şeyleri söyleyecek biriymiş gibi baklyordu..." (s. 75). Burada yazar, Guido, Alaeddin Hoca ve zencefil çayı arasındaki bakışım ile aslında Batı ve Doğu'nun bakışımlı oluşlarını vurgular. Aynı şekilde kolaj, Kur'an'dan Dehr suresinden yapılan bir alıntı ile de kendini gösterir.

Hilmi Yavuz'un anlatısına kendi şiirlerinden dizeler aktardığı da görülür. Yazarın, Taormina'ya Yaz Şiirleri kitabında yer alan büyü 'sün, yaz! şiirinden dizeler aktarıp şiirlerini anması ve hatta şairini hatırlayamamış gibi davranarak anlatıya üstkurgusal düzlemde oyunsuluk katar.

“ah bellek, acı bellek!

hem arisin sen

Turkish Studies - Language and Literature

Volume 14 Issue 3, 2019 


\section{hem kimbilir hangi gülden}

kalma diken?"

"Bir dilin ötekine çevrilebilirliği konusunda, her zaman çok ciddi kuşkularım olduğunu biliyorsunuz. Size daha önce de söylemiştim bunu (Ah bellek, acı bellek! diyordu bir şair, kimdi unuttum!)" (s. 3)

\section{b) Kuyu}

Gerçek ile kurmacanın iç içe olduğu bir başka nokta ise anlatıya gerçek hayattaki bir gazete yazısının kolaj tekniği ile dâhil edilmesidir (s. 197). Yazar, Çetin Altan'ın Sabah gazetesinde yayımlanan Türk folklorundaki "Kuyu anası" arketipini açıklayan yazısından alıntılar yapar.

\section{Yazarın da Anlatının Bir Karakteri Olması}

Üstkurmaca anlatılarda "yazar metnin içine girer ve kendisinden karakter listesinde bahseder." (Waugh, 1996: 74). Üstkurmacanın bu kullanımı kitabın gerçek yazarının kurmaca içinde bir karakter olması şeklinde görülebileceği gibi kurmacanın içindeki kurmaca yazarın anlatmakta olduğu kurmacanın bir karakteri olması biçiminde de görülebilir.

\section{a) Taormina}

Taormina'nın birinci kurgusal düzlemi Hilmi Yavuz tarafından kaleme alınırken ikinci kurgusal düzlem, Yusuf Horoz adlı bir kurmaca yazar tarafından kaleme alınır. Yusuf Horoz, kurguladığ Taormina adlı anlatının bir karakteri olarak okuyucunun karşısına çıkar. Yazar-kahraman küçük bir kaldırım üstü kahvehanesinde oturduğunu ve çocukluğunun deniz ve beyazlık içerisinde Taormina'da geçtiğini ifade eder:

"Benim çocukluğum Taormina'da geçti. Bu yüzden de kendimi çok bahtiyar sayıyorum. Deniz ve beyazlık imgelerinin bende hep var olagelmiş olması da, bundan dolayıdır." (s. 53) Yusuf Horoz kendisini, kaleme aldığı Taormina adlı hayali kentin bir ferdi olarak anlatır.

\section{b) Fehmi K.'nın Acayip Serüvenleri}

Anlatıcının aynı zamanda anlatının bir kahramanı olarak okuyucunun karşısına çıktığı görülür. “....ben bu anlatıda, Fehmi K. 'nın dediği gibi, 'Selim'i tanımamış, ama, tanıyabilme olasıllğg bulunduğu halde tanımamış, tanıyamamış olan biri 'yim', ve bir 'anlatı kişisi' olarak betimliyorum onu” (s. 140).

Anlatıcı kimi zaman yazar anlatıcı olarak da yerini alır: "SSimdilik bu anlatının kahramanlarını (yoksa, tiplerini mi demeliydim) bir yana bırakarak, onlara boş vererek, kendimi, anlatı yazarı olan ben'i anlatsam? Evet, bunu anlatsam, nasll olur? ... Bunu anlatmak, yani kendimi bu anlatiya sokmak, beni anlatıya ilişkin bir sürü teknik sorundan kurtaracak üstelik! Hem de keyif verecek." (s. 113)

Anlatı yazarı ve aynı zamanda kahramanı olarak bazı şeylerden habersiz olduğunu da belirterek kimliğine gerçeklik katar: “... sevgili okurlar, ben de bu anlatının yazarı olarak, Selim Taşıl, Fehmi K. ve Anette'i bir yana bırakıp kendi yaşamöykümü (okurların, eleştirmenlerin ve tabii, bu arada pederin, müdahalelerinden kurtulabildiğim sürece) anlatırken, ailemize iliş̧kin birtakım gizli kalmış hakikatleri ögreniyorum!” (s. 134).

\section{c) Kuyu}

Kиуи'da da anlatının asıl yazarı olan Hilmi Yavuz'un aynı zamanda anlatının bir karakteri olarak da okuyucunun karşısına çıktığı görülür. Kendisini bir anlatı karakteri olarak olay örgüsüne dâhil eden Hilmi Yavuz, 1966 yılında yapılmış kendi apartmanının altında bir kuyu olup olmadığını anlamak için apartmanın kapıcısı Niyazi ile kalorifer dairesinde inceleme yapar. Ölüm ile kuyu arasında bir ilgi kuran yazar, işe öncelikle anlatısını yazabileceği uygun bir kuyu aramakla başlar: "Hilmi Yavuz, bu son 
anlatısın (şimdi yazmakta olduğu anlatıyı) yazmaya başlamadan önce onu nerede yazacă̆ını düşündü̈. Ne yazacağını biliyordu kuşkusuz; ama nerede yazabileceğini bilmiyordu ... ” (s. 165).

Ölüm ve kuyu, mezarı imleyen bir ikili olarak düşünülebilir. Nitekim kimi mutasavvıflar, ölmeden önce mezarda vakit geçirmiş, ölümün soğuk yüzünü mezarda daha iyi duyumsayarak dünyanın faniliğini hissetmeye çalışmışlardır. Tasavvuf kültürüne yabancı olmayan Hilmi Yavuz'un kuyuya böyle bir anlam kattığı da düşünülebilir. Bu his, Kuyu'da ölümü yazma biçiminde görülür. "Şimdi, artık, rahatlıkla itiraf edebiliriz: Hilmi Yavuz'un anlatısın yazmak için kuyuyu seçmesi, anlatının 'ölüm'le ilgili olmasındandr. Hilmi Yavuz, kuyuyla ölüm arasında bir bağıntı olduğunu ve ölüm 'ün (kuşkusuz, kendi ölüm'ü olacaktı bu!) ancak bir kuyuda yazılabileceğini düşünüyordu!’'(s. 171). Kendi ölümü hakkında birtakım deneyimler elde edebilmek, ölümü en birinci elden hissedebilmek ve yaşayabilmek için anlatısını kuyuda yazmak ister.

Taormina ve özellikle Fehim K.'nın Acayip Serüvenleri'nde görülen anlatıcı karmaşasına Kuyu'da da yer verilir. Ancak yazarın verdiği ipuçları dikkatle izlendiğinde, yer yer hayal kırıklığına uğranılsa bile birtakım tespitlerde bulunmak olanaklıdır. Hilmi Yavuz, anlatılarını çözümlemeye çalı̧an okuyucularına bu hayal kırıklığını sıklıkla yaşatır. Böylece anlatının kendisiyle birlikte anlatıcısı veya aktarıcısı bir gizeme dönüşür. Киyu' da genellikle yazar anlatıcı ile kahraman Hilmi Yavuz birbirlerinden ayrılır, ancak kimi yerlerde aynileşirler. Örneğin çocukluk anılarını anlatan yazar anlatıcı, anılarında Hilmi Yavuz'un şahsında belirir: "Çocuklar neden doymazlar sahi? Baba doğru söylüyor, daha bir saat önce, koca bir dilim tereyağlı reçelli ekmek yedi Hilmi Yavuz; ve 'karnımızdaki şeytan' d düşünüyor; İzeddin Şadan Amca ise, ihtinak- i rahim'i yani kadınların 'içindeki şeytan'ı! Mirim... (İzzeddin Amcam burada babama göz kirplyor) harekete başlayarak... Histeri, mâlûm... Babam ise, bel fitığından yakınıyor, ve alışveriş ederken ağır kaldırmamaya yemin ediyor.” (s. 185).

Yazar anlatıcı çoğu yerde Hilmi Yavuz ile birbirinden ayrılır. Anlatıcı, hâkim bakış açılı bir konuma yükselir: "Bu anlatıyı yazmak için bulduğu kuyu, Hilmi Yavuz'u büyük ölçüde keyiflendirmiş olmalıdır ki, kuyudan gülerek çıkıyor... Kuyu ve ölüm bağıntısı üzerine Hilmi Yavuz'un ne yazacağını bilebilmemiz mümkün değil, ama ben ne söyleyeceğimi biliyorum. Ölüm ve kuyu bağıntısı, Hilmi Yavuz'un oturduğu apartmanın hemen karşısındaki devasa otel inşaatı dolayımında somutlanıyor." (s. 174-175). Otel inşaatı, anlatıda çabuk geçiştirilen ancak kültürel ve lirik içermeleri olan bir eğretilemedir. Kuyunun zıddı manasında bir metafor olarak anlatıya katıldığı görülür. Kuyu, hayatın mülemmâ tarafını; devasa otel inşaatı ise hayatın yoz tarafını ifade eder ve kapitalist dünyayı simgeler. İnşaatın tozları, Hilmi Yavuz'da şiiri imleyen annesini, yani lirik olan her şeyi örter.

\section{Anlatıcının Satır Aralarında Okuyucuya Bilgi Vermesi}

Üstkurmaca anlatıların önemli özelliklerinden biri de yazarın, anlatı içerisinde okuyucuya birtakım bilgiler sunmasıdır.

\section{a) Taormina}

Yusuf Horoz'un, Alaeddin'in sahaf dükkânının önünde okuduğu Ali Emiri Efendi'nin Acaib 'ül Letaif adını taşıyan Hitay Sefaretnamesi hakkında okuyucuya detaylı bilgi verilir. 1422'de Hoca Gıyaseddin El Nakkaş'ın yazdığı ve Şeyhülislam-ı esbak Küçükçelebizâde İsmail Asım Efendi'nin tercüme ettiği bu sefaretnamenin Taormina' da yer alan özeti şöyledir:

Timur'un oğlu Mirza Şahruh'un Çin imparatoruna gönderdiği elçiler delegasyonunda bulunan Hoca Giyaseddin 1419'da Herat'tan yola çıkar. Uzun ve zorlu bir yolculuktan sonra Hitay'a varan elçi delegasyonu imparatorun sarayına davet edilirler: "Saray kapısının iki yanında beşer filin hortumları arasından geçilerek içeriye girildi." (s. 59). İmparatora atların içinde bulunduğu hediyeleri takdim eder; kendileri ve imparatorları için takdim edilen hediyeleri alırlar. Ancak kendisine hediye edilen atlardan biriyle ava çıkan imparator attan düşer ve ayağını incitir. Hoca Gıyaseddin'in içinde bulunduğu delegasyon heyeti bu üzücü olaya çok üzülürler. Bu seyahat iki yıl on ay beş gün sürer. Hoca Gıyaseddin 
seyahat esnasında tuttuğu notları Herat'a döndükten sonra toplar ve böylece ortaya Acaib 'ül Letaif, diğer adıyla Hıtay Sefaretnamesi çıkar. (s. 54-62)

\section{b) Fehmi K.'nın Acayip Serüvenleri}

Anlatıda yazar, ata yurdu olan Güneydoğu kentinde, Siirt'te konuşulan dil hakkında bilgiler sunar. Üzüm bağı anlamına gelen "karm" sözcüğü ile buğday anlamına gelen "hıntah" sözcüğünün eski Babil'de yaygın olarak kullanılan bir sözcük olduğu bilgisini verir (s. 144).

\section{c) Kuyu}

Anlatıda "Sümbül Sinan Türbesi” (s. 179), bu türbenin yanındaki kuyu (s. 180) ve anlatı yazdı̆̆ 1 kuyunun etimolojisi (s. 181) hakkında okuyucuya detaylı bir bilgi verildiği görülür.

Yazar 1926 yılında yayımlanan René Laforgue'un yazdığı bir makale hakkında bilgi sunar. Makalede geçen "skotomisation ve skotoma" terimleri hakkında detaylı bilgiler sunarak okuyucuyu bilgilendirir. (s. 196). Skotoma teriminin, retinada görme alanında beliren boşluk (karanlık) anlamında, aynı zamanda maskeleyen (gizleyen, örten) anlamlarında kullanıldığı bilgisini sunar. Daha sonra da Freud'un düşünceleriyle de beraber bu terimin, bireyin bilinçli istekleriyle bilinçdışı arzuları arasındaki ayrılığı ortaya koyan kuramsal bir kavram olduğu bilgisini verir.

\section{1. Özdeșleșme}

Postmodern eserlerin önemli bir özelliği yazarın karakterler üzerinden okuyucunun kafasını karıştırması ve okuyucuyu şaşırtmasıdır. Yazar, bunlarla hem anlatının bir oyun ve kurgudan ibaret olduğunu vurgulamak hem de okuyucuların dikkatinin canlı olup olmadığını ölçmek ister. Bütün bunlar aslında yazarın kalem gücünün göstergesi olarak kendini gösterir. Üstkurmaca tekniği olarak görülen özdeşleşme, aynı karakterin anlatı içinde bazı bölümlerde isim değişikliğine uğraması ya da yazarın bir karakterin kimliğinde hayat bulması biçiminde düşünülebilir.

\section{a) Taormina}

Bodrum'da, menkıbelerden çıkıp da gelmiş izlenimi veren ve Doğu mistisizmini yansıtan Alaeddin Hoca özdeşleşmeye en güzel örneklerden biridir: "O dükkâna sabah, ekmek ve gazete almaya bir Calvino ya da Dostoyevski kişi olarak değil, Eşrefoğlu Rumi'nin Menakıb’indan yola çılkarak gitmek daha doğru olacaktı. Eşrefoğlu'nun İbn Musa ile yaptığı konuşmayı anımsayarak, sabah ekmeğimi alırken, Glyaseddin Hoca'nın yüzüne gizemli gizemli bakacak ve, 'Dâvete icâbet etmek lâzımdır' diyecektim." (s. 76). Bir cami hocası olan bu kişi, bakkallık da yapar. Yusuf Horoz, her sabah ondan ekmek ve gazete alır. Alaeddin Hoca, ona bir şeyler gizleyen ya da başkalarının öğrenmesi sakıncalı olan şeyler anlatacakmış gibi bakar. Bu kişinin, anlatıda daha sonra Gıyaseddin olarak anılır.

Bodrum'da sabahları ekmek ve gazete aldığı bakkal Alaeddin Hoca'yı görünce kendini Eşrefoğlu Yusuf olarak hisseden Yusuf Horoz'a yazar, metinlerarası ilişki ile Somuncu Baba'nın nidasını duyumsatır: ' ... yaşlı bakkaldan ekmek alırken, Bursa'da, İbn Musa'nın 'somunlar, müminler!' sesini duyan Eşrefoğlu Rumi gibi duyumsuyordum kendimi." (s. 75) Taormina'da Yusuf Horoz, Eşrefoğlu Rumi'nin eseri “Menakıb”a yer vererek kendini Eşrefoğlu Rumi ile özdeşleştirir ve bu durumu, "Dikkat edilirse burada, Kitab'a, yani Menâkıb'a sıkısıkıya bağımlı kaldı̆̆ım görülecektir... Kitab'a tastamam bağlı kalarak, bir yaşamı yeniden kurmak (burada söz konusu olan yaşam benimki mi, yoksa Eşrefoğlu'nunki miydi? Orası belirsiz) gerekiyordu." (s. 76) ifadeleriyle de açıkça dile getirir.

\section{b) Fehmi K.'nın Acayip Serüvenleri}

Yazar, okuyucularını zaman zaman test ederek onların dikkatini ölçmek ister. Bunu da en güzel biçimde anlatıcı ve yazar karmaşasıyla yapar. Anlatıcıların tam olarak ayırt edilememesi için söylenenler okuyucuları sınama olarak düşünülebilir: "Hakikat şuydu ki, Marquis de Rollebon, Selim Taşıl'ın ta kendisiydi ve Rollebon'un yaşamöyküsünü yazarken, kendi yaşamöyküsünü yazdiğını 
biliyordu... O zaman sorulmast gereken şuydu: Sartre, Roquentin'e Marquis de Rollebon'un yaşamöyküsünü yazdırırken, Rollebon'un Selim Taşıl olduğunu biliyor muydu? Dahası, acaba Sartre, Roquentin'in Fehmi K. olduğunu biliyor muydu?” (s. 102) Okuyucular çoğu zaman romanlardaki kahramanlarla kendilerini özdeşleştirirler. Hilmi Yavuz bunu açıkça "Okur, o tiple kendini özdeşleştirme olanağ kazanır (s. 102)" ifadeleri ile dile getirir. Yazmakta olduğu anlatıdan Sartre'nin haberi varmış gibi, Sartre'nin kendi romanında Hilmi Yavuz'un roman tiplerini canlandırdığını ifade eder. Aslında Hilmi Yavuz, kendi yazmakta olduğu romanın kahramanlarıyla Sartre'nin yazmış olduğu romanın kahramanlarını özdeşleştirir: "Yazarın talihi yaver giderse, ilerde, yani çok sonraları, yazllacak bir romanın tiplerini, kendi romanında yazma olanağını bulabilirler. Sartre'da da bu böyle olmuştur." (s. 102). Burada Hilmi Yavuz kendisini Sartre ile Sartre'nin yazmış olduğu La Nausée (Bulantı) adlı romanında kahraman olan ve bir anlatı yazarı olarak canlandırılan Roquentin ile Fehmi K.'yı ve iç halkada ise Roquentin'in yazmış olduğu Marquis de Rollebon adlı kahraman ile Selim Taşıl'ı özdeşleştirir. Bununla beraber yazar anlatıcının Fehmi K. ile ilgili yaptı̆̆ bazı betimlemelerden hareketle "... dazlaktır Kavkl; -ve tepesini örtmek için saçlarını bir yandan ötekine doğru yatırarak taramaktadır.” (s. 89), “... Fehmi K., sigarayı bırakalı neredeyse on yıl olmuştur, ama her sabah işyerindeki masasına oturur oturmaz, masa komşusu Anette Hanımdan bir adet sigara isteminde bulunmaktan ve bu sigarayl, elbette yakmadan, dudă̆ına iliştirme alışkanlı̆̆ından bir türlü vazgeçmemiştir.” (s. 91). Fehmi K.'nın Hilmi Yavuz ile özdeşleştiği görülür. Bu özdeşleşme ile aslında ortaya konulmak istenen karakterler arasındaki kimlik kaymasıdır. Hilmi Yavuz, bu özdeşleşme ve kimlik kayması ile anlatının bir kurmaca olduğunu, yaşanılanların bir oyundan ibaret olduğunu imler. Çünkü postmodern metinler için yapılan bu türden dil oyunları kurgunun güçlenmesindeki en önemli etkenlerdir.

\section{c) Kuyu}

İç içe üç kurgunun bulunduğu Kuyu'nun merkezinde yer alan Hilmi Yavuz, zaman zaman kahramanların geçmişini bilen yazar anlatıcı ile kimi zaman da başkahramanla özdeşleşir. Anlatıda ağırlıklı olarak Hilmi Yavuz'un çocukluk anılarına tanık olunur. Üstkurmaca düzleminde okuyucuya aktarılan anıların hacimce fazlalığının, çerçeve öyküyü meydana getirmede yeterli olmadığı görülür. Anlatı yazmak için kuyu arayan yetişkin Hilmi Yavuz'un, anlatının başında gördüğü Şahmeran ve kuyu motifli rüyanın (s. 167) daha sonra duyduğu fantastik efsaneden (s. 201) izler taşıması, kahraman ile özdeşleşen yazar anlatıcı bakımından bize ipuçları verir. Zira bu efsane, çocuk Hilmi Yavuz'a anlatılmamış; yazar anlatıcı tarafından Almanya'da yerleşik bir işçinin bant kaydından aktarılmıştır. Anlatıcının, başkasının ağzından kaydettiği bu efsaneyi daha sonra Hilmi Yavuz'un rüyasında görmesi, esas kurgu ve çerçeve öykünün, yetişkin Hilmi Yavuz'un anlatı yazmak için kuyu araması ile birlikte sunulur. Kahramana anlatılmayan bir efsanenin daha sonra onun tarafından görülmesi anlatıcı-kahraman birlikteliğini imler.

Kuyu'da Wittgenstein'in ölümü yazmanın imkânsızlığına dair görüşüne karşı, kahramanın şahsında ölümü yazmaya çalışır Hilmi Yavuz. Nitekim Neci Bey’in kuyudan çıkarılan cesedinde, anlatının ilk cümlesinden bir sözcük yer alır: “... acı suyun ıslattı̆̆ı kâğıtları birbirinden ayırmak zor olmuştu. 'Bu kâğgtlardan birinde bir sözcük, evet sadece bir sözcük okunabiliyordu' (diye yazlyor Hilmi Yavuz bu anlatısında)... okunabilen o tek sözcük, anlatının ilk sözcügüudü: SON” (s. 214). Bunlar, anlatının ilk cümlesi ile karşılaştırıldığında durum açıklığa kavuşur. İlk cümlede son yazılıdır. Ancak diğer sözcükler belirtildiği üzere suyun etkisiyle okunamamaktadır: "Hilmi Yavuz, bu son anlatısin (şimdi yazmakta olduğu anlatıyı) yazmaya başlamadan önce onu nerede yazacă̆ını düsündü." (s. 165). Hilmi Yavuz, Neci Bey'le özdeşleşir ve Neci Bey'in şahsında kendi ölümünü yaşar. Neci Bey'in cebinden çıkan anlatıdaki cümle ile Kuyu'nun ilk cümlesindeki sözcük benzerliğinden başka bir somut benzerlik Neci Bey'in ölmeden önce söylediği isimle anlaşılır. Neci Bey'in ölürken son sözü $\hat{A} h$ Theodolinda, Theodolinda Barolini olur. (s. 214) Bu isim Hilmi Yavuz'un, İngiltere'deki İtalyan as1llı 
kız arkadaşının adıdır. Verilen ipuçları, kendi ölümünü yazmaya çalışan Hilmi Yavuz’un, bunu gerçekleştirdiğini okuyucuyla paylaşması anlamına gelir.

Ayrıca Neci Bey'in cebinden çıkan kâğıttaki yazılarla anlatının ilk cümlesindeki sözcük benzerliğine okuyucunun dikkat etmesi beklenir. Burada okuyucunun dikkati ölçülür ve aynı zamanda kurmacanın iç içeliği sağlanır.

\section{Yazarın ve Anlatıcının, Metne Müdahil Olması}

\section{a) Fehmi K.'nın Acayip Serüvenleri}

Olay örgüsü bakımından oldukça sade olan Fehmi K. 'nın Acayip Serüvenleri, anlatıcı çeşitliliği nedeniyle farklı bir kurgu ile sunulur. Anlatıda çoğulcu anlatım kullanılması, anlatıcının tam olarak ayırt edilememesine neden olur ve böylece üstkurmaca anlatıların en önemli özelliklerinden biri olan okuyucuyu yanıltma ve şaşırtma tekniği kullanılır. Yazarın/anlatıcının anlatının akışı içerisinde metne müdahil olduğu şu şekilde ifade edilir: "Şimdi anladınız $m l$, bu anlatıdaki, deyim yerindeyse, parazitlerin nedenini? Anlatı dümdüz giderken, birden ortalı̆̆ın karışıvermesini, radyonun parazit yapması gibi araya başka seslerin girmesini başka nasıl açılklayabilirdim ki?" (s. 98).

Anlatıya müdahil olma durumu yazarın, kimi zaman anlatıcıya müdahalesi ve onu yönlendirmesi ile de gerçekleşebilir: “Anette'nin annesi Sara Hanım ve Sara Hanım'ın kardeşi İshak (İzak, Yitsakh) bu anlatıya girmek için sira beklemektedirler ve onların anlatiya girebilmesi için benim İbrahim, Musa ve Yusuf ile ilgili o "Karm günü" anısını anlatmanın uygun olduğu, yazar tarafindan bana bildirilmiştir." (s. 145). Bu ifadelerle yazar, anlatıcıya müdahale ederek anlatıda kendi varlığını gösterme ihtiyacını duyar.

Bu üstkurmaca tekniğinin bir başka kullanım biçimi ise anlatıcının, metinde araya girerek yazar hakkında konuşmasıdır:

“Öyle ya, ya Fehmi Kavkı’nın yazarı, anlatı kişilerinin hamamböceklerine dönüşebileceğini biliyordu ise?" (s. 85).

"Bu anlatının yazarına göre" (s. 85) ifadeleri ile de anlatıcının metne müdahil olduğu görülür.

Bazen de yazar, metne müdahil olma işini anlatıcıyı aradan çekerek doğrudan kendisi yapar ve böylece anlatıda varlığını daha baskın biçimde hissettirir. Postmodern ve üstkurmaca anlatılarda/eserlerde yazarın, kendini sıklıkla hissettirdiği görülür:

“...(utanmadan! Insan sikılır be adam, kendini Sartre ile Foucault ile karşılaştırıyor, baksanıza!...)... (Yalancı! Ben bu anlatının yazarıyım. Bilmez miyim Selim Taşıl Efendi’nin daha tek satır bile yazmadığını!)” (s. 106).

“Anette, bu kez Selim Taşıl'ı gerçekten dinlemeye hazırlanıyor, -çünkü, annesi Müstehase Hanımla Yahya Kemal Bey arasindaki 'muaşaka'yı (bu sözü Anette'in etmesi olanaksız. Bu, yaşlı bir okur olarak bendenizin müdahalesidir) gerçekten merak ediyor. Bir mütevazı anlatı yazarl olarak, ikide birde söze karıştı̆̆ım için özür dilemek isterim.” (s. 108).

Yazarın anlatıya bu denli müdahil oluşu, söz konusu anlatının kurmaca bir metin olduğu, bütün bu kurgunun yazarın kendisi tarafından tasarlandığı gerçeğini okuyucuya göstermek ve yazılanların aslında birer oyun olduğunu okuyucuya telkin için dile getirildiğini düşünmemiz gerekir.

\section{Okuyucunun Dikkatinin Kurgusal Ögelerin Üzerine Çekilmesini Sağlama}

Yazar, postmodernizmin en önemli unsurlarından biri olan kurmaca ve gerçeklik arasındaki ilişkiyi belirginleştirmek için okuyucunun dikkatini kurgusal ögelerin üzerine çeker. Üstkurmacanın bu kullanımında genellikle yazar, anlatıcı ve kahraman arasındaki ilişkinin ortaya konması hedeflenir. 
Böylece okuyucuyu, anlatının kurmaca düzlemiyle ilgili sorular ve sorunlar üzerinde düşündürülmeye çalışılır.

\section{a) Fehmi K.'nın Acayip Serüvenleri}

Yazar anlatıcının, anlatının kurmacadan başka bir şey olmadığı görüşünü ortaya koymaya çalışır. Anlatıda anlatıcı çeşitliliğinin ve belirsizliğinin yaşanması, bu sayede okuyucunun kafasının karıştırılması ve metnin yazılma tekniği hakkında bilgi verilmesi bir gerçeğe hizmet etmek için yapılır. $\mathrm{O}$ da anlatının bir kurgu olduğu ve bu kurguyu inşa etmek için de birtakım oyunlara başvurmanın gerekliliğidir. Bununla birlikte üstkurmaca anlatılarda sıç̧a görülen girift anlatıcı ve yazar müdahalesine açıklık getirmeye çalışılarak metnin iç içe geçen kurmaca özelliğine ayrıca bir vurgu yapilır:

Anlatıya Franz Kafka'nın Dönüşüm adlı romanına atıf yapılarak başlandığı görülür: "Fehmi Kavkl erkenden uyandl ve dosdoğru aynaya baktl. Aynada gördü̈̆̈̈ kendisiydi; ve bir gece önce hamamböceğine dönüşmemişs olduğu için Tanrı'ya şükretti. Öyle ya, Fehmi Kavkl bir anlatı kahramanıydı (bu anlatının kahramanı) ve anlatı kahramanlarının sık sik değilse bile, arada bir, hamamböceklerine dönüştükleri biliniyordu. Çoğu kez, okurların bile bildiği bir gerçekliktir bu ..." (s. $85)$.

Yazar daha sonra Fehmi K. ve Anette'den kurmaca karakteri olarak, bu anlatının yazarı olarak kendisinden de bahseder: "Fehmi K. ile Anette nasıl birer (kurmaca) anlatı kahramaniysalar, bendeniz de, işte tastamam öyle kurmaca bir anlatı yazarıyım. Bana bu anlatıy yazlyormuş gibi yapma ödevi verildiği için böyle davranıyorum. Biraz karışık oldu, ama yalınkat bir söyleyişle durumu şöyle özetleyeceğim: Ben, Fehmi K. ile Annette'i yazıyorsam, beni de bir anlatı yazarı olarak, başka birisinin yazdığından kuşkunuz olmasın! O birisini de bir başkası yazacaktır ve ad infinitum!” (s. 98). Birbirine sarmal şekilde geçen bu anlatıcı-yazar bağlamı okuyucuların dikkatine sunulur. Yazar, yazdıklarının kurmaca ve hayal ürünü olduğunu somutlaştırmak için anlatının yazılış/kurgulanış süreci hakkında okuyuculara bilgi verir. Yazar çok açık şekilde, ey okuyucu elinde tutmuş olduğun kitabı ben yazdım/kurguladım, demek ister.

\section{Kahramanın Kurmaca Bir Karakter Olduğunun Bilincinde Olması}

Üstkurmacanın önemli özelliklerinden olan bu kullanım genellikle kahramanın kendisinin bir kurmaca karakter olduğunu bildiğini belirtmesi ya da bir anlatı karakteri olarak okuyucuya seslenmesi şeklinde görülür. Üstkurmaca anlatıda yazar, çokkatmanlı bir yapı oluşturarak kahramana somut bir yaşam yükler ve onun gerçek dünyadaki okuyucular ile iletişimini sağlayarak kendi varlığının bilincinde olmasını sağlar. Üstkurmaca tekniğinin oyunsuluk boyutunu ortaya koyan kahramanın kurmaca bir karakter olduğunun bilincinde olması, metnin kurgusunu gerçek olmayan bir dünyaya iter.

\section{a) Fehmi K.'nın Acayip Serüvenleri}

Üstkurmaca anlatılarda görülen kahramanın kendisinin bir anlatı karakteri olduğunun bilincinde olmasının, Fehmi K. ile örneklendirildiği görülür: "Fehmi K., o yaz sabahı evinden iş yerine doğru yürürken, içinde, yüreğinin ta derininde bir hafiflik hissetti ve birden bu hafifliği, hiçbir sorunu olmayışına borçlu olduğunu ayrımsadı. Ne kadar güzel! Gerçekten hiçbir sorunum yok! diye dile getirdi bu düşüncesini ve bunalımlı bir tip olarak tasarlanmadı̆̆ için Tanrıya şükretti." (s. 90-91). Fehmi K.'nın, kendisinin bir kurmaca karakter olduğunun bilincinde olduğu ve iş yerine giderken yazarın, kendisini sağlıklı ve sorunsuz olarak tasarladığı için bunun sevincini yaşadığı görülür.

Selim Taşıl da kendisinin kurmaca bir karakter olduğunun farkındadır: "Selim Taşıl, kendisini tanımamış olan birinin kendisini betimleyemiyeceğini mi söyledi? Selim ’in böyle mimetik ve doğalcı bir yazın kuramını savunmayacak kadar incelikli bir entelektüel donanıma sahip olduğunu düşünüyorum. Belki de şunu, bir anlatı kişisi olarak, kendisinin nasıl betimlendiğine kayıtsız kalamayacağını söylemek 
istedi. "'s. 140-141). Selim Taş1, kendisinin bir kurmaca karakteri olarak nasıl betimleneceği hususunda birtakım düşüncelere sahiptir. Yazar da Selim Taşıl'ı bir kurmaca karakteri olarak betimleyeceği sırada Selim Taşıl'ın kendisinin betimlenmesi hususunda bu betimlemeye katkıda bulunacağını düşündüğünü belirtmektedir.

Anlatının önemli kahramanlarından biri olan Fehmi K, Franz Kafka'nın “Dönüşüm” romanında böceğe dönüşen Gregor Samsa gibi kendisinin de bir kurmaca karakter olduğunu bilir. Bu nedenle Fehmi K, bir sabah uyandığında kendisi gibi bir kurmaca karakter olan Gregor Samsa gibi hamamböceğine dönüşmediğini görür: “... Fehmi Kavkı uyanmış ve bir hamamböceğine dönüşmediğini görmüştü. ” (s. 85). Anlatıda Tolstoy’un "Savaş ve Barış” romanındaki Bezukhov'un gözlüklerinden (s. 85) bahsedilmesi de yine Fehmi K'nin kendisini bir anlatıda kurmaca karakter olduğunu bilmesinin sonucudur. Anlatıda Fehmi Kavkı ile Franz Kafa bakışımlı olarak kurgulanır. Bu durum isimlerin baş harflerinde de kendini gösterir.

\section{Okuyucunun Dikkatini Ölçme}

Yazar, metnin kurgusuna birtakım zekâ oyunları katarak aslında okuyucuyu "yazma oyunu"na dâhil eder. Bu teknikle okuyucunun anlatıdan daha büyük bir keyif alması beklenir. Çünkü okuyucunun tüm dikkati metnin satır aralarında canlı olacak; sonunu kestiremediği bu anlam olaylarını satır aralarında kelimelerin, cümlelerin içinde yakalamaya çalışacaktır. Dolayısıyla yazar ile okuyucu arasındaki bir tür oyun söz konusu olacaktır. Çünkü yazar ile okuyucunun birbirine yaklaşması ancak "oyun" ile mümkün olur. "Metnin kurgusal gizlerini çözmeye çalışmak, yazarın romanını nasıl kurguladığını bulup çıkarmak için çaba göstermek, kurmaca edimi ile oyun oynamak demektir. Bu da, okurun romanının içinde oynadı̆̆ bu oyunu üstkurmaca düzleminin bir ögesi yapar. Çocuksu bir bilmece/bulmaca tutkusuyla bütünleşen bu oyunsu eğilim aracılığıyla, roman içinde son derece ciddi boyutlar yakalamak olasıdır. Oyun ögesinin bir amacı da budur çağımız romanında" (Ecevit, 2008: 148-149). Okuyucu, yazarın hem söylediğine hem de söylemediğine oyun aracılığı ile ulaşır.

Kurmaca metinde gerçek ile yaşam arasındaki sınır ortadan kalkar. "Anlatı ormanına girdiğimizde, bizden yazarla birlikte kurmaca anlaşmasının altına imza koymamız istenir.” (Eco, 2009: 90). Yazarın, kurmaca metin içinde okuyucuyla konuşması ve okuyucuya romanı okuma esnasında nelere dikkat etmesi gerektiğini satır aralarında söylemesi üstkurmacanın sıkça rastlanan özelliklerindendir.

\section{a) Taormina}

Postmodern anlatılarda yazar sıklıkla okuyucunun dikkatini ölçer: “... saray kapısına giden yolda sağll sollu yerleştirilmiş beşer beyaz filin arasından geçmişler (Taormina'da, tastaman on bir beyaz filin olduğu biliniyor).” (s. 25). Yazar, Taormina'da saray yolunda karşıllklı duran beşer filin varlığından bahsederken bu fillerin sayısının on adet değil tam on bir adet olduğunu belirtir. Bu durumda karşlıklı duran fillerin sayısının beşerden on adet olması gerekirken on bir adet diye bahsedilmesi, tamamıyla okuyucunun dikkatinin ölçülmek istenmesiyle ilgilidir. Çünkü üstkurmaca anlatılarda yazar, okuyucunun dikkatinin daima canlı ve postmodern bir metin okuduğunun farkında olmasını ister.

\section{b) Fehmi K.'nın Acayip Serüvenleri}

Fehmi K. 'nın Acayip Serüvenleri'de de anlatıcı yazar, yeşil mürekkepli kalemle kendisinin iki defter hâlinde yazdığını söylediği Acaib'ül Letaif 'in önce "topu topu 35 sayfa" olduğunu söylerken daha sonra "tam 38 sayfa" olduğunu söylemesi (s. 72-73), yine babasının önce "bağırsak kanamasindan öldü" "̆ünü (s. 38) belirtirken daha sonra "kalpten gitti" "ğini (s. 69) belirtmesi tamamiyla yazar anlatıcının bilinçli tercihidir ve postmodern bir teknik olan üstkurmaca anlatılarda görülen bu durum okuyucunun dikkatini canlı tutmak ve ölçmek içindir. 


\section{c) Kuyu}

Kuyu adlı anlatıda Neci Bey'in ölürken son sözü "Âh Theodolinda, Theodolinda Barolini” (s. 214) olur. Bu isim Hilmi Yavuz'un, İngiltere'deki İtalyan asıllı kız arkadaşının adıdır. Theodolinda isminin daha önce metin içinde kullanıldığının okuyucunun dikkati ile fark etmesi beklenir. Aynı zamanda Neci Bey'in ölürken cebinden çıkan ıslanmış kâğıtta okunan tek kelimenin (bu kelime "SON" kelimesidir) (s. 214), anlatının ilk kelimesi olduğuna okuyucunun dikkat etmesi beklenir. Bütün bunlarla aslında Hilmi Yavuz'un, Neci Bey'in şahsıyla özdeşleştiğine ve yine onun şahsında kendini gerçekleştiğine okuyucunun dikkat edip etmediği ölçülmek ister.

\section{Metinde Okuyucunun Konuşması ve Metne Müdahil Olması}

\section{a) Fehmi K.'nın Acayip Serüvenleri}

Hilmi Yavuz'un kimi zaman anlatı yazarı, kimi zaman okuyucu ve kimi zaman ise eleştirmen olarak okuyucunun karşısına çıkarak anlatıya müdahale etmesi, anlatının sohbet düzleminde ilerlemesini sağlar. Üstkurmaca anlatılarda görülen bu durum, anlatının oyun olduğu gerçeğini bir kez daha vurgulamak için bilinçli yapılan bir yazma şeklidir. Bu durum ile okuyucunun anlatıyı anlamlandırması ve zihninde konumlandırması alışılagelmiş anlatılara/metinlere bakarak sorunsallaştırılmış olur.

"Biz okurlar, olup bitenleri baştan sona kadar bildiğimiz için, burada, sesimizi çıkarmadan, bu öykünün yenibaştan anlatılmasına sessizce tanık olmayı düşünüyoruz. Demek istediğimiz şudur ki, bundan sonra okuyucu değil, sadece dinleyici olarak varız bu anlatıda. Sesimizi çıkartmıyorsak, bu bizim burada bulunmadı̆̆ımı anlamına gelmemeli. -Buradayız ve seni dinliyoruz!” (s. 101).

Anlatıda yazarın okuyucuya soru yöneltmesi üzerine okuyucunun cevap verdiği görülür. “... Selim Taşıl, Fehmi K. ve Anette üçlüsüne dönebiliriz; -dönebilir miyiz, sevgili okurlar?

-Dönelim bakalım." (s. 134).

Yazar, anlatıya Selim Taşıl adında yeni bir karakter eklediğinin ve bu karakteri niçin eklediğinin açıklamasını yapar. Ardından da okuyucunun bu konudaki düşünceleri dile getirilir: "Kendisi, Fehmi K. 'nın yakın arkadaşıdır ve bu anlatıya girme sırası gelmiştir. -Anlatı yazarı, sanki bir sürü kurmaca kişi bu anlatıya girmek üzere kuyruğa girmiş gibi konuşadursun, kazın ayağı hiç de böyle değildir ve bu anlatıya girmek için sıra bekleyen de yoktur. Bu, olsa olsa, anlatı yazarının hüsn-ü kuruntusu olabilir. Tersine, ben bir okur olarak bu anlatıya girmek için sira beklemek şöyle dursun, birçoklarının bu anlatıdan dışarı çıkmak için can attığını söyleyebilirim. Hoş, çıksak da nereye gideceğiz? O da ayrı..." (s. 100).

Anlatıcının, zaman zaman okuyucunun dilinden yazar hakkında bilgi sunduğu görülür: "Açıkça şunu söylemekte yarar var: Bu anlatının yazarı, anlaşılan Rumelhard'ı okumuş olmalıdır. Bu gibi yazarlık oyunlarının, biz iyi okurların gözünden kaçmayacağını Hilmi Yavuz'un iyi bilmesi gerekir.” (s. 92). Yazar Hilmi Yavuz'un anlatıda kendine yer vermesi, gerçek ile kurmacanın iç içe geçmesine ve birbirinden ayırt edilememesine işarettir. Anlatıcı, zaman zaman yazarı gözlemleyerek yazar sıfatıyla Hilmi Yavuz'un, kendi kaleme aldığı anlatı kahramanı hakkındaki görüşlerini okuyucuya sunar: "Sözlerin burasında Anette'in kizardiğını biz okurlar fark ediyoruz, Fehmi K. 'nın bunu fark etmesine olanak yok; çünkü bu anlatımın yazarı olan hergele onun Anette'e bakmasını istemiyor. Nedenini ben söyleyeyim sevgili okurlar, bu anlatının yazarl, Fehmi K. 'yı düpedüz kıskanıyor... Benim, bu anlatının yazarı olarak, Anette'e belli bir yakınlık duyduğum doğrudur. Tolstoy, Karenina' ya, Flaubert Emma'ya ne kertede yakınlık duyduysa benim de Anette'e o kertede yakınlı duyduğum söylenebilir." (s. 103, 105). Bu ifadelerde yazar Hilmi Yavuz'un okuyucu kimliği ile anlatıda yer aldığ ve kendi eserine dışardan bir okuyucu olarak eleştirel yaklaştığı görülür. 


\section{Sonuç}

Hilmi Yavuz, tarihi mirasa ve geleneğe dayalı olarak geliştirdiği şiir poetikasını sanat anlayışında da sergiler. Postmodern düzlemde kaleme aldığı anlatılarında gelenekle kurduğu bağı bir adım daha ileriye taşır. Tarihten ve gelenekten yararlanma bu kez postmodern bir yapıya bürünür. $\ddot{U}_{\mathcal{C}}$ Anlatı'da yazar, anlatıcı, eleştirmen ve okuyucu olmak birden fazla kimlikle okuyucunun karşısına çıkar. Anlatılar, farklı üstkurgusal düzlemlerin birbiri içine geçtiği, uzamlar arasında gelgitlerin yaşandığı bir yapı arz eder. Dil oyunlarına sıkça başvurulan anlatılarda anlatıcı karmaşası yaşanır, okuyucu cevapsız pek çok soruyla baş başa bırakılır. Postmodern düzlemde gerçekleşen bu durum onları üstkurmaca eserler yapar. Bu yönüyleriyle ÜÇ Anlatı Türk edebiyatının ilklerindendir.

$\ddot{U}_{\zeta}$ Anlatı, yazarın çocukluğuna ve bilinçdışına yapılan istem dışı bir yolculuktur; bu nedenle eser, felsefî̀ ve psikolojik veriler 1şığında ilerleyen üstkurmaca bir eser olarak değerlendirilmelidir. Hilmi Yavuz anlatıların ilki olan Taormina' da sığınma mekânı olarak tasarladığı hayali kent imgesini, bir felsefe kurgu biçiminde dizayn eder. Burada geçen ayna imgesi ise bilinçli olarak tercih edilir ve bu imge ile gerçek yaşamın tüm unsurları, çeşitliliği ve çoğulculuğu anlatıya/metne taşınır.

İkinci anlatı olan Fehmi K. 'nın Acayip Serüvenleri'nde bir kurmaca karakter olan Fehmi K. ile birlikte anlatının yazarı Hilmi Yavuz'un yaşamından ve hayatından kesitler eş zamanlı fakat girift bir şekilde sunulur. Üstkurmaca tekniğiyle oluşturulan "gerçek ile kurmaca arasındaki ilişki" Hilmi Yavuz ve anlatı kahramanı Fehmi K. karakteri ile hayat bulur.

Son anlatı olan Киyu'da yazar anlatıcı ile kahraman anlatıcının birbirine dönüştüğü görülür. Yazar anlatıcı Hilmi Yavuz, Freud ve Wittegenstein'a inat kendi ölümünü şahsında yaşamaya ve yazmaya kalkışır. Neci Bey ile anlatının sonunda özdeşleştiğini okuyucuya duyumsatarak kendi ölümünü yazdığını ilan eder, böylece bu ölüm ile kendi ölümünün gerçekleştiğini belirtir. Kuyu'da metinlerarası ilişki düzleminde Freud'un Psikanalist kuramına ve Wittgenstein'a göndermeler okuruz. Çoğunlukla yazar anlatıcı olarak okuyucunun (o kuyucunun) karşısına çıkan Hilmi Yavuz, aynı zamanda hem anlatı yazmak için kuyu arayan bir kişi hem de çocukluk anılarını anlatan felsefik kahraman olarak karşımıza çıkar. Bedenini bir mekân olarak değerlendirir. İnsanın bünyesinde olan pek çok duygu, düşünce ve isteğe ancak insanın bilinçdışına inildikçe ulaşılır. Kuyu'da insan hem fiziki hem de ruhi yapısı küçültülmüş bir dünya mekânına benzetilir ve onunla özdeşlik kurulur. Beden fiziksel açıdan küçük olmasına karşın aslında algısal yönden içine dünyaları sığdıran büyük bir kozmo mekândır. Hilmi Yavuz, Kuyu'da hem kendi çocukluk belleğine hem de entelektüel gelişiminin derinliklerine iner.

Hilmi Yavuz, Cumhuriyet sonrası Türk şiirinde önemli bir yere sahiptir. Edebiyatın pek çok alanında nitelikli eserler kaleme almıştır. Bir üstkurmaca örneği olan $\ddot{U} c ̧$ Anlatı adlı eseriyle postmodern düzlemde anlatı yazarı olduğunu da ispatlamıştır. Felsefi boyutu güçlü olan anlatılarında Yavuz, başta kendi var oluşunu, hayatı ve sosyal yaşamı inşa eden hemen her şeyi sorgular. Hayata farklı bir perspektiften bakmayı ve bakılabileceğini gösterir. Anlatılarda gerçekle kurmaca arasındaki gelgitler, sınırlarının belirsizleşmesi ve zihinleri diri tutan kurgu yapıları dikkat çeker. Hilmi Yavuz, anlatılarında kendini bir yazar, kahraman, eleştirmen hatta okuyucu olarak yansıtıp metinlerarasılık ve üstkurmaca

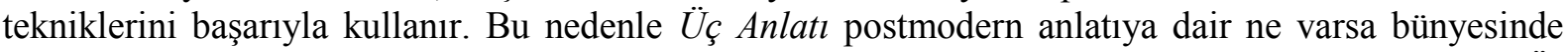
fazlasıyla barındırır. Postmodern anlatının özelliklerini belirgin ve çok açık biçimde yansıtışı $\ddot{U}_{c ̧}$ Anlatı'yı teknik olarak öykünülmesi gereken bir konuma taşır. Böylece Hilmi Yavuz şiirde olduğu gibi anlatılarında da Hocalığını ön plana çıkarır.

\section{KAYNAKÇA}

Aktaş, Ş. (1991). Roman sanatı ve roman incelemesine giriş. Ankara: Akçağ Yayınları.

Aktulum, K. (1999). Metinlerarası ilişkiler. Ankara: Öteki Yayınevi. 
Arıkan, S. (2015). Kayboluştan yeniden doğuşa: Üç Anlatı'da yazarın tin yazımı. A. Ü. Türkiyat Araştırmaları Enstitüsü Dergisi (TAED), 54, Erzurum.

Bakırcığlu, N. Z. (1999). Başlangıcından günümüze Türk romanı. Ötüken Yayınları: İstanbul.

Demir, Y. (2002). Bir üstkurmaca olarak Müşahedat. İstanbul: Dergâh Yayınları.

Doltaş, D. (1996). Fehmi K.’nın acayip serüvenleri. Varlık, 1070, 20-23.

Ecevit, Y. (2001). Türk romanında postmodernist açılımlar. İstanbul: İletişim Yayınları.

Ecevit, Y. (2008). Orhan Pamuk'u okumak. İletişim Yayınları: İstanbul.

Eco, U. (1995). Anlatı ormanlarında altı gezinti. İstanbul: Can Yayınları.

Eco, U. (2011). Genç bir romancının itirafları. İstanbul: Kırmızı Kedi Yayınevi.

Emre, İ. (2004). Postmodernizm ve edebiyat. Ankara: Anı Yayınları.

Erkan, M. (2016). Hilmi Yavuz'un Üç Anlatı'sında uzamın ontolojisi ya da ontolojinin uzamı. A. $\ddot{U}$. Türkiyat Araştırmaları Enstitüsü Dergisi [TAED], 56.

Gümüş, S. (2003). Yazının sarkacı roman. İstanbul: Doğan Kitapçılık.

Işıksalan, N. (2007). Postmodern öğreti ve bir postmodern roman çözümlemesi: Kara Kitap / Orhan Pamuk. Anadolu Üniversitesi Sosyal Bilimler Dergisi, 7(2), 419-466.

Karabostan, A. (2006). Graham Swift'in Waterland, David Lodge'un Small World ve Martin Amis'in London Fields adlı romanlarında üstkurmaca tekniğinin incelenmesi. Yayımlanmamış Yüksek Lisans Tezi, Ankara Üniversitesi, Sosyal Bilimler Enstitüsü, Ankara.

Karaburgu, O. (2009). Fehmi K’nın acayip serüvenlerinde postmodernist İzler. Uluslararası Türk Dili ve Edebiyatı Kongresi, 27-28 Ağustos 2007.

Karadeniz, H. (2014). Orhan Pamuk'un romanlarında üstkurmaca. Yayımlanmamış Yüksek Lisans Tezi, Ahi Evran Üniversitesi, Sosyal Bilimler Enstitüsü, Kırşehir.

Menteşe, O. B. (1996). Bir düşün yolculuğu. Ankara: Bilkamat Yayınları.

Moran, B. (1994). Türk romanına eleştirel bir bakış. İstanbul: İletişim Yayınları.

Ören, A. (2016). Üstkurgu/üstkurmaca üzerine. Ankara: Hece Yayınları.

Parla, J. (2011). Türk romanında yazar ve başkalaşım. İletişim Yayınları: İstanbul.

Parla, J. (2012). Don Kişot'tan, bugüne roman. İletişim Yayınları: İstanbul.

Sazyek, H. (2002). Türk romanında postmodernist yöntemler ve yönelimler. Hece Dergisi Türk Romanı Özel Saylsi, 65/66/67, 493-509.

Tarım, R. (1996). Üç Anlatı dolayısıyla Hilmi Yavuz’un “Kuyu”su. Varlık, 1065, 41-44

Todorov, T. (2004). Fantastik. (Çeviri: Nedret Öztokat). İstanbul: Metis Yayınları.

Uyanık, G. (2011). Peter Stamm'ın Agnes adlı romanında üstkurmaca ve metinlerarası ilişkiler. Erzurum: Salkımsöğüt Yayınları.

Waugh, P. (1996). Metafiction. London: New Fetter Lane.

Yavuz, H. (1995). Üç Anlatı. İstanbul: Can Yayınları.

Yavuz, H. (1997). Derrida ve Eleştiriler [Okuma Notları]. Varlı, 1078.

Yavuz, H. (1998). Geçmiş yaz defterleri. İstanbul: Can Yayınları. 
Yavuz, H. (1999a). Gülün ustası yoktur. İstanbul: Can Yayınları.

Yavuz, H. (1999b). Şiir henüz. İstanbul: Est\&Non.

Yavuz, H. (2001). Erguvan sözler. İstanbul: Can Yayınları.

Yavuz, H. (2004). Gelenek ve postmodernizm. Virgül dergisi, 73, 44.

Yavuz, H. (Şubat 2005). Bulanık defterler. İstanbul: Yapı Kredi Yayınları.

Yavuz, H. (2006). Şiirim Gibi Yaşadım. (Hazırlayan: Can Bahadır Yüce). İstanbul: Dünya Kitapları. 